\title{
Corporate Taxation in the Global Economy
}




\section{INTERNATIONAL MONETARY FUND}

\section{IMF POLICY PAPER}

\section{CORPORATE TAXATION IN THE GLOBAL ECONOMY}

IMF staff regularly produces papers proposing new IMF policies, exploring options for reform, or reviewing existing IMF policies and operations. The following documents have been released and are included in this package:

- A Press Release summarizing the views of the Executive Board as expressed during its February 21, 2019 consideration of the staff report.

- The Report, prepared by IMF staff and completed on January 22, 2019 for the Executive Board's consideration on February 21, 2019.

The IMF's transparency policy allows for the deletion of market-sensitive information and premature disclosure of the authorities' policy intentions in published staff reports and other documents.

Electronic copies of IMF Policy Papers are available to the public from

http://www.imf.org/external/pp/ppindex.aspx

\section{International Monetary Fund Washington, D.C.}


March 10, 2019

\section{IMF Executive Board Reviews Corporate Taxation in the Global Economy}

On February 21, 2019, the Executive Board of the International Monetary Fund (IMF) discussed a paper setting out the current state of international corporate income tax arrangements.

The policy paper Corporate Taxation in The Global Economy, explores options that have been suggested for their future development, including several now being considered in global fora and considering the contribution of the Fund to debates and processes now underway.

The IMF is not a standard setting body in this area. Intensive discussions of possible changes to the international tax system are now underway in the Inclusive Framework on Base Erosion and Profit Shifting (BEPS)/the OECD, and the paper is intended to complement that work, reflecting the distinct contribution that the IMF's broad membership, mandate, expertise and capacity building work position it to make.

The paper builds on an earlier IMF analysis (2014), which stressed the macro-criticality of international corporate tax arrangements, the importance of cross-country spillovers in analyzing corporate tax reform and the particular vulnerability of low income countries to profit shifting activities. The paper discussed on February 21 continues these themes. It provides an update on what has been achieved, an account of remaining challenges, and a high-level overview of key economic aspects and implications of alternative schemes, some of which are now under discussion. Finally, it stresses the importance of fully inclusive cooperation in this area and reflects on the supportive role that the Fund can play in this context.

The paper notes the considerable positive developments achieved since the previous paper was discussed, including the G20/OECD BEPS project and the expansion of the OECD's body for reaching consensus around these issues to include over 125 countries in the new Inclusive Framework. It notes too, however, that issues remain in continued opportunities for profit shifting, and that concerns regarding tax competition and, more fundamentally, the 
allocation of taxing rights across countries now underlie much of the discussion within the Inclusive Framework.

The paper does not endorse any specific proposals for international tax reform. It recognizes that views differ widely. Rather the paper identifies and discusses potential criteria by which alternatives might be assessed — with special attention to the circumstances of developing countries — and provides some empirical analysis to support discussions.

The paper stresses the need to maintain and build on the progress in international cooperation on tax matters that has been achieved in recent years, and in some respects now appears under stress. It considers the supportive role that the Fund can play in this context, including by drawing on its capacity building work to inform the standard setting that others lead, and stresses the importance of cooperation among the international organizations active in this area, including through the Platform for Collaboration on Tax.

\section{Executive Board Assessment ${ }^{1}$}

Executive Directors welcomed the opportunity to take stock of recent developments in international aspects of corporate taxation, and offered preliminary observations on alternative proposals currently being debated. They acknowledged the importance of these issues to all Fund members in their efforts to raise revenues in an efficient and equitable manner, and the potential for significant cross-border spillovers.

Directors welcomed the significant progress made in addressing corporate tax avoidance and enhancing multilateral cooperation, notably by the G-20/OECD project on Base Erosion and Profit Shifting, and the Inclusive Framework that has broadened the scope of cooperation to many non-OECD countries. At the same time, they noted that there remain shortcomings in current international tax arrangements, and that many countries face pressures to introduce unilateral action. Directors agreed that much remains to be done to find sustainable global solutions, building on the progress achieved so far to ensure fairness, inclusiveness, and broad consensus, although their views differed on the extent of needed reforms and the roles of relevant bodies.

As an important element of the current debate, Directors welcomed the discussion on tax challenges associated with digitalization. They recognized that this is a difficult issue, technically and politically, and that views on whether special treatment is needed, and if so in what form, continue to differ widely. For the long term, a number of Directors considered that it would not be desirable or feasible to design ring-fenced solutions. Directors looked forward to the final report from the OECD to the G-20 in 2020, which could serve as a basis for a cooperative approach going forward.

\footnotetext{
${ }^{1}$ An explanation of any qualifiers used in the summing up can be found here: http://www.imf.org/external/np/sec/misc/qualifiers.htm.
} 
Directors noted other challenges that have yet to be fully addressed. They welcomed the emphasis in the paper on profit shifting, which is a particular concern for developing countries. They also pointed to the damage from continued harmful tax competition, including the risk of a race to the bottom, while recognizing the importance of respecting national sovereignty in tax matters. Some Directors were of the view that the benefits of fair tax competition should also be acknowledged.

Directors noted that views on the relative merits of alternative reform proposals vary to a great extent. They emphasized that much depends not only on the detail of specific proposals and their implementation but also on the relative importance attached to the various assessment criteria. Noting the tentative nature of the staff assessment, Directors stressed that it should be interpreted and communicated with caution. While Directors considered it too early to endorse any of the particular alternatives, they found the discussion a useful analytical complement to existing debates. Specifically, many Directors saw the benefit of minimum taxation in dealing with harmful tax avoidance and profit shifting practices. Directors emphasized that, to better inform the ongoing debate, considerable further analysis of the reform proposals is needed with respect to legal issues, practical consequences, including distributional effects, and implications for various groups of countries with similar or unique characteristics.

Directors underscored the need for an inclusive process for discussing international taxation, especially as fundamental issues in the allocation of taxing rights come under discussion. Many Directors felt that the current governance arrangements, with the OECD as a central body and standard-setter and supported by the Inclusive Framework, are broadly appropriate. At the same time, many Directors saw room for improvements, including to enhance the representation of developing and low-income countries in the decision-making process.

Directors emphasized the important role of the Fund in the area of international corporate taxation, focusing on its universal membership, macroeconomic perspective, and analytical expertise. They stressed in particular the value of Fund advice and extensive capacity building, helping member countries to implement best practices on tax policy and administration. While recognizing that the Fund is not a standard-setting body in international taxation, they noted that the Fund is well placed to undertake economic analyses of the impact of possible changes, both within and across countries, as well as to ensure that their implications for developing countries are adequately considered. In this context, most Directors advocated a more active role for the Fund in providing analytical contribution, influencing the debate, and fostering broader cooperation. A number of Directors stressed that efforts to bridge data gaps would need to take account of confidentiality issues and limited capacity in many developing countries. 
Directors underscored the importance of continued close collaboration with the OECD and other international organizations active in this area, to ensure that the Fund's work remains complementary to, and avoids duplication of, that of others. They noted that the Platform for Collaboration on Tax provides a useful framework for bringing together the IMF, OECD, $\mathrm{UN}$, and World Bank, and could continue to play an active role in supporting international tax coordination. 


\section{INTERNATIONAL MONETARY FUND}

January 22, 2019

\section{CORPORATE TAXATION IN THE GLOBAL ECONOMY}

\section{EXECUTIVE SUMMARY}

The international corporate tax system is under unprecedented stress. The G-20/OECD project on Base Erosion and Profit Shifting (BEPS) has made significant progress in international tax cooperation, addressing some major weak points in the century-old architecture. But vulnerabilities remain. Limitations of the arm's-length principle-under which transactions between related parties are to be priced as if they were between independent entities - and reliance on notions of physical presence of the taxpayer to establish a legal basis to impose income tax have allowed apparently profitable firms to pay little tax. Tax competition remains largely unaddressed. And concerns with the allocation of taxing rights across countries continue. Recent unilateral measures, moreover, jeopardize such cooperation as has been achieved.

This paper reviews alternative directions for progress. The call for taxation "where value is created" has proved an inadequate basis for real progress. There now seems quite widespread agreement that fundamental change to current norms is needed-but no agreement, as yet, on its best form.

Key concerns are to better address both profit shifting and tax competition-and ensure full recognition of the interests of emerging and developing countries. Low income countries (LICs) are especially exposed to profit shifting and tax competition (and have limited alternatives for raising revenue) and their limited capacity is now stretched further by increased complexity. For them, securing the tax base on inward investment is key.

Alternative international tax architectures differ not only in their economic properties, but in how far they depart from current norms and the degree of cooperation they require. No scheme is without difficulty, but there are clear opportunities for improvement: ${ }^{1}$

- Minimum taxes on outbound investment can offer significant though incomplete protection against profit shifting and tax competition and generate positive spillovers for other jurisdictions (other than those with low tax regimes). Minimum taxes on inbound investment can be especially appealing for LICs. These schemes have the merit of being readily designed to complement current norms. But there is

\footnotetext{
${ }^{1}$ It is assumed that primary taxing rights in relation to natural resources would remain with the location country.
} 
a tradeoff between ease of administration and risk of such bluntness as to potentially jeopardize investment. Further, distortions remain (through for instance the relocation of parent companies) and underlying weaknesses of the system are patched rather than fixed. While minimum taxation has advantages over current arrangements, it is not clear that it alone would prove a robust long-term solution.

- Further from current practice, but addressing current weaknesses more fully, schemes of residual profit allocation (RPA)—broadly, allocating a normal return to source countries, and sharing the residual on a formulaic basis. Such schemes can substantially reduce profit shifting, as would other unitary approaches, while retaining the familiarity of the arm's length principle for straightforward cases. But much depends on the way in which residual profits are allocated: tax competition is more limited the greater the weight placed on allocation by the destination of sales (or similar criterion), given the relative immobility of final consumers. The residual profit allocation approach sets the scene for constructive discussion of the allocation of taxing rights in relation to some part of international corporate profits, though securing agreement on such apportionment will be difficult.

- Some allocation of taxing rights to destination countries features in many proposals, including some residual profit allocation schemes: this is the most effective way to address tax competition and profit shifting. Among such schemesand most remote from the current debate among policy makers-border adjusted taxes - combining value-added tax (VAT)-like treatment of trade with a wage subsidy - face potential World Trade Organization issues (because border adjustability resulting in imports and exports being taxed differentially is not currently permitted for (direct) corporate taxes) and may amplify refund problems that arise under the VAT; and unilateral adoption could have significant adverse spillover effects. They remain, nonetheless, the most complete solution to tax competition and profit shifting. To the extent that erosion of the corporate tax leads to increased reliance on the VAT moderated by a desire to keep labor taxes low, the default outcome in the absence of more deliberate reform may be implicit but imperfect taxation of this kind.

The economic impact and administrability of these schemes requires further analysis-especially for emerging and developing countries. Even for advanced economies, little is known, for instance, about the nature and extent of residual profits. Data and research gaps for low income countries remain substantial.

\section{Some improvements can be achieved unilaterally or regionally, but more} fundamental solutions require stronger institutions for global cooperation. Addressing the distinct concerns of developing countries is critical, as is making full use of the differing comparative advantages and mandates of relevant international organizations. 
Approved By

Vitor Gaspar and

Rhoda Weeks-Brown
Prepared by Michael Keen, Victoria Perry, Ruud de Mooij, Alexander Klemm, Christophe Waerzeggers, Cory Hillier, Kiyoshi Nakayama, Aqib Aslam, Sebastian Beer, Shafik Hebous, Kors Kool, Sébastien Leduc, Li Liu, Zayda Manatta, Dinar Prihardini, and Alpa Shah. Research assistance was provided by Victor Mylonas and Alice Park and production assistance by Ana Popovich and Claudia Salgado.

\section{CONTENTS}

Acronyms and Glossary $\underline{5}$

INTRODUCTION

TAKING STOCK

A. Recent Developments

B. Key Problems with Current Arrangements $\underline{10}$

THE DIGITALIZATION DEBATE 14

ALTERNATIVE ARCHITECTURES $\underline{18}$

A. Evaluating Alternative International Tax Systems____

B. Minimum Tax Schemes____ 21

C. Border-Adjusted Profit Taxes_____ $\underline{25}$

D. Formula Apportionment ___ 31

E. Sharing Residual Profit _____ $\underline{35}$

F. Assessment_____ $\underline{40}$

GOVERNANCE OF THE INTERNATIONAL TAX SYSTEM AND THE ROLE OF THE

INTERNATIONAL FINANCIAL INSTITUTIONS

References

BOX

1. Varieties of Digital Services Tax

\section{FIGURES}

1. Estimated Revenue Losses from Profit Shifting in 2013

2. Trends in Statutory CIT Rates____

3. The Rise and Demise of the Largest Ten Companies____ 
4. Corporate Income Tax Revenue by WEO Income Group 1990-2017___ 20

5. DBCFT and CIT Revenues_____ 28

6. Factors Shaping the Revenue Impact of the DBCFT ___

7. Tax Base Effect of Formula Apportionment_____

8. Excess of Current CIT Bases over Routine Return___

\section{TABLES}

1. Estimated Revenue Losses from Profit Shifting for the G-7___ 11

2. Summary Assessment, Assuming Global Adoption____ $\underline{41}$

\section{APPENDICIES}

I. Consultation________

II. The International Tax Framework_Core Elements and Concepts___ $\underline{49}$

III. Multilateral Measures_BEPS and ATAD ____

IV. International Provisions of the TCJA___

V. Profit Shifting: Evidence and Opportunities____

VI. Tax Competition ___ _

VII. Some Developments Concerning Developing Countries____ $\underline{59}$

VIII. Digital Service Taxes: Enacted and Proposed____ $\underline{61}$

IX. Revenue Implications of Formula Apportionment____ $\frac{63}{69}$

X. The Scale and Allocation of Routine and Residual Profits ___ 


\section{Acronyms and Glossary}

\begin{tabular}{|c|c|}
\hline ACE & Allowance for Corporate Equity \\
\hline AEOI & Automatic Exchange of Information \\
\hline ALP & Arm's Length Principle/Pricing \\
\hline ATAD & Anti-Tax Avoidance Directive of the EU \\
\hline BEAT & Base Erosion Anti Abuse Tax (under the TCJA) \\
\hline $\mathrm{B} 2 \mathrm{~B}$ & Business to Business \\
\hline B2C & Business to Consumer \\
\hline BEPS & Base Erosion and Profit Shifting \\
\hline $\mathrm{CbC}$ & Country by Country reporting \\
\hline CEN & Capital Export Neutrality \\
\hline CEMAC & Communauté Economique et Monétaire de l'Afrique Centrale \\
\hline CFC & Controlled Foreign Corporation \\
\hline CIN & Capital Import Neutrality \\
\hline $\mathrm{CIT}$ & Corporate/Company Income Tax \\
\hline CON & Capital Ownership Neutrality \\
\hline CSO & Civil Society Organization \\
\hline DBCFT & Destination-Based Cash Flow Taxation \\
\hline DBACE & Destination-Based Allowance for Corporate Equity \\
\hline Destination country & Country in which the purchaser is located (same as market country) \\
\hline DPT & Diverted Profits Tax \\
\hline DST & Digital Services Tax \\
\hline DTA & Double Tax Agreement \\
\hline EOI & Exchange of Information \\
\hline FA & Formula Apportionment \\
\hline FATF & Financial Action Task Force \\
\hline FDI & Foreign Direct Investment \\
\hline FDII & Foreign Derived Intangible Income (under the TCJA) \\
\hline GAAR & General Anti-Avoidance Rule \\
\hline GF & $\begin{array}{l}\text { Global Forum on Transparency and Exchange of Information for Tax } \\
\text { Purposes }\end{array}$ \\
\hline GILTI & Global Intangible Low Taxed Income (under the TCJA) \\
\hline LIC & Low Income Country \\
\hline LOB & Limitation of Benefit \\
\hline LSR & Location Specific Rent (rent uniquely associated with a specific location) \\
\hline Market country & Country in which the purchaser is located (same as destination country) \\
\hline MLI & $\begin{array}{l}\text { Multilateral Convention to Implement Tax Treaty Related Measures to } \\
\text { Prevent BEPS (The 'Multilateral Instrument') }\end{array}$ \\
\hline MNE & Multinational Enterprise \\
\hline Normal return & Minimum return required on an investment \\
\hline OIT & Offshore Indirect Transfer \\
\hline
\end{tabular}




\begin{tabular}{|c|c|}
\hline PE & Permanent Establishment \\
\hline PCT & Platform for Collaboration on Tax \\
\hline PPT & Principal Purpose Test \\
\hline Profit shifting & $\begin{array}{l}\text { Shifting of where profits are booked for tax purposes, and encompasses } \\
\text { base erosion }\end{array}$ \\
\hline Rents & Earnings in excess of the normal required return \\
\hline Residence country & $\begin{array}{l}\text { For a corporation (most frequently the location of managerial functions; } \\
\text { occasionally the place of incorporation) }\end{array}$ \\
\hline Residual profit & Profits in excess of routine \\
\hline Routine return & $\begin{array}{l}\text { Broadly equivalent to normal return, commonly as identified by transfer } \\
\text { pricing methods }\end{array}$ \\
\hline RPA & Residual Profit Allocation \\
\hline Source country & Jurisdiction in which production of goods or services occurs \\
\hline TA & Technical assistance \\
\hline TCJA & Tax Cuts and Jobs Act: The informal title of the 2017 U.S. tax reform \\
\hline Territorial system & Business profits are taxed only in the source country \\
\hline User participation & Contribution by the user of the product to the business model \\
\hline WAEMU & West African Economic and Monetary Union \\
\hline Worldwide system & $\begin{array}{l}\text { Business profits taxed in the residence country, wherever in the world } \\
\text { they arise-generally with credit for taxes paid in source countries }\end{array}$ \\
\hline
\end{tabular}




\section{INTRODUCTION}

1. This paper takes stock of the current state of international corporate tax arrangements and considers options for their future development. It builds on the analysis in IMF (2014) to focus on developments-practical and intellectual-since then. ${ }^{2}$ That paper, which will be referred to for background at several points, stressed the macrocriticality of the issues at stake, described international tax arrangements and their considerable vulnerabilities, and sketched alternatives.

\section{There has been significant progress on coordinated measures, most notably the} G-20/OECD Base Erosion and Profit Shifting (BEPS) project. ${ }^{3}$ This project sought to limit the most egregious types of international corporate tax avoidance by achieving multinational agreement on technical fixes and new/improved standards in such areas as transfer pricing and treaty abuse. It did not, however, seek to change the fundamentals of the century-old international tax architecture.

\section{But there have also been unilateral developments going beyond the BEPS outcomes-} reshaping the debate and in some cases jeopardizing the coordinated approach of BEPS. The most central are: (1) The 2017 U.S. tax reform (the 'Tax Cuts and Jobs Act', TCJA), which, in addition to implementing BEPS, introduced major structural novelties in its international provisions; and, (2) The adoption/announcement by several countries of short-term measures in the one area in which the BEPS process has yet to find common ground: dealing with corporate tax aspects of digitalization.

\section{With the international tax system in a state of flux, ideas for far-reaching reform are} receiving serious attention, ${ }^{4}$ reflecting wide recognition that the roots of current problems-not only continued vulnerability to avoidance but unaddressed pressures from tax competition-are deep. The destination-based cash flow tax and residual profit allocation schemes discussed in IMF (2014) had rarely featured in policy discussions; since then, the former has been widely discussed in the U.S., ${ }^{5}$ and variants of the latter proposed by the U.S., U.K., and European Commission.

\section{Against this background of risks to order in international taxation, this paper} considers options for fundamental reform. It begins by reviewing recent developments and the key problems that remain, and then discusses one of the most prominent: the international tax implications of digitalization. It then identifies and assesses more fundamental options for reform before considering the capacity of current governance arrangements to achieve substantial

\footnotetext{
${ }^{2}$ It draws too on a public consultation, key points from which are summarized in Appendix I.

${ }^{3}$ The outcome documents are at http://www.oecd.org/tax/beps/beps-actions.htm.

${ }^{4}$ Schön (2017, pp.1) speaks of an "overwhelming consensus that the international tax regime needs to be reshaped"-but notes too that "this is not a self-evident truth."

${ }^{5}$ Following the proposal in A Better Way: https://abetterway.speaker.gov/ assets/pdf/ABetterWay-TaxPolicyPaper.pdf.
} 
improvement. ${ }^{6}$ Finally, issues for discussion are raised with guidance sought from Directors on the impact of the paper on IMF advice going forward, including on the role of the Fund and the Platform for Collaboration on Tax (PCT).

\section{TAKING STOCK}

6. This section reviews developments in international taxation since IMF (2014) and outlines remaining problems. For background, Appendix II provides a primer on current international tax arrangements.

\section{A. Recent Developments}

\section{There has been substantial progress in aspects of multilateral tax coordination: ${ }^{7}$}

- The G-20/OECD BEPS project, launched in 2013, aimed to close gaps in international tax rules that allowed corporate tax bases to be eroded or artificially shifted to low/no tax jurisdictions. The guiding principle was to "ensure that profits are taxed where economic activities take place and value is created." 8 To this end, the project addressed 15 problematic areas, with the final 'BEPS package' of 2015-endorsed by G-20 leaders-including four 'minimum standards' and amendments to core OECD guidance (on transfer pricing, for instance) and delineation of preferred practices (such as on interest deductibility). ${ }^{9}$

- To facilitate and support BEPS implementation, the OECD has developed an innovative multilateral instrument (MLI) that enables simultaneous changes to multiple Double Tax Agreements (DTAs), and established an 'Inclusive Framework' (IF) whose (now 127) members commit to the BEPS package and its consistent implementation, including the minimum standards. Many countries have been very active in ensuring BEPS-consistency of their rules. ${ }^{10}$

- The European Union's Anti-Tax Avoidance Directive (ATAD) makes some of the BEPS outcomes, beyond the minimum standards, mandatory for member states (on interest deductibility, for instance) and also includes other measures (for example in requiring a common General Anti-Avoidance Rule (GAAR)).

- The cross-border exchange of tax-related information has continued to make remarkable progress, notably within the framework of the Global Forum on Transparency and Exchange of

\footnotetext{
${ }^{6}$ It is assumed that it is desired to retain a substantial role for business-level taxation; and that personal-level taxes can be used to achieve preferred outcomes in the final taxation of capital incomes. These are not trivial assumptions.

${ }^{7}$ Details are in Appendix III.

${ }^{8}$ OECD (2015f), pp. 4.

${ }^{9}$ The Platform for Collaboration on Tax is preparing 'toolkits' to support developing countries address various issues in international taxation, BEPS-related and other.

${ }^{10} \mathrm{~A}$ useful tracking of measures adopted is at https://www.ey.com/gl/en/services/tax/ey-beps-developments-tracker.
} 
Information for Tax Purposes (GF, or Global Forum). The importance of the movement towards Automatic Exchange of Information (AEOI) is confirmed by emerging evidence that this can be especially effective, ${ }^{11}$ including in combating tax evasion. Both the G-20/OECD and the EU (for non-EU members) publish lists of jurisdictions deemed non-cooperative, and the G-20 and the EU have raised the possibility of countries adopting 'defensive measures' on this basis.

- In 2012 the Financial Action Task Force (FATF) standards were upgraded to include tax crimes as predicate offenses to money laundering. They specify that countries must make the beneficial ownership information of legal entities and arrangements available to national competent authorities, including tax authorities; and recommend that countries ensure they can rapidly exchange information related to money laundering and predicate offences.

\section{There have also, however, been important unilateral initiatives going beyond BEPS, and in some cases challenging established norms. These include:}

- The adoption of 'diverted profits taxes' (DPTs) in the U.K. (2016) and Australia (2016), seen by some as early departures from the consensual approach of the BEPS project.

- The Tax Cuts and Jobs Act, bringing not only a large cut in the federal U.S. corporate income tax (CIT) rate (from 35 to 21 percent) but fundamental and novel changes in its international provisions (Appendix IV) - one of which some have suggested may violate WTO rules and is under review for consistency with the BEPS minimum standard on harmful tax practices.

- The adoption and proposal of 'digital service taxes' (DSTs) on revenues associated with selected digital activities. These might be seen as attempts to circumvent the norm that only firms with physical presence are liable to corporate income tax, and it has been suggested that the EU proposal may violate WTO non-discrimination rules. ${ }^{12}$

9. The rapid trend towards the uncoordinated adoption of anti-avoidance measures risks creating distortions. At one end of the spectrum General and (to a lesser extent) Specific AntiAvoidance Rules (G/SAARs) inevitably create uncertainties around notions of the artificiality of business arrangements. At the other, while unilateral measures have generally been crafted to be compatible with existing domestic laws and double tax agreement obligations, they may in some cases result in double taxation, where the residence country may not provide full credit for their payment. Double taxation is not inherently damaging - the total tax paid is ultimately what matters most-but it can imply differential treatments across different taxpayers or arrangements, and distort business decisions.

\footnotetext{
${ }^{11}$ Beer, Coelho, and Leduc (2019) find that AEOI reduces country-specific deposits in low-tax jurisdictions by 30- 40 percent-broadly in line with estimates in Johannesen (2014), Menkhoff and Miethe (2017) and Casi, Spengel and Stage (2018). Pointing to the importance of full participation, several of these studies note, as do Johannesen and Zucman (2014), signs of offshore deposits being relocated to other jurisdictions.

12 Hufbauer and Lu (2018).
} 
10. These trends may also amplify complexity and uncertainty-and potentially create significant tensions. The BEPS project is not generally regarded as simplifying a system that was already largely incomprehensible to all but the most expert. BEPS implementation, moreover, was seen as creating additional uncertainty for both taxpayers and tax administrations. ${ }^{13}$ These concerns are greatly amplified by the measures outside the BEPS outcomes that several countries have adopted or proposed. Dispute is now elevated to the political level, as some measures are seen as being unfairly targeted and violating established norms. Talk of 'tax wars' is premature-but international tax relations have rarely been so sour.

\section{B. Key Problems with Current Arrangements}

\section{Opportunities for Profit Shifting Remain ${ }^{14}$}

\section{Revenue losses from profit shifting have been substantial for many advanced} economies-and even more so for developing countries (Figure 1 and Table 1). Quantification remains difficult-even the signs of the country-specific effects in Table 1 differ ${ }^{15}$ —but work since IMF (2014) confirms the significance of the issue.

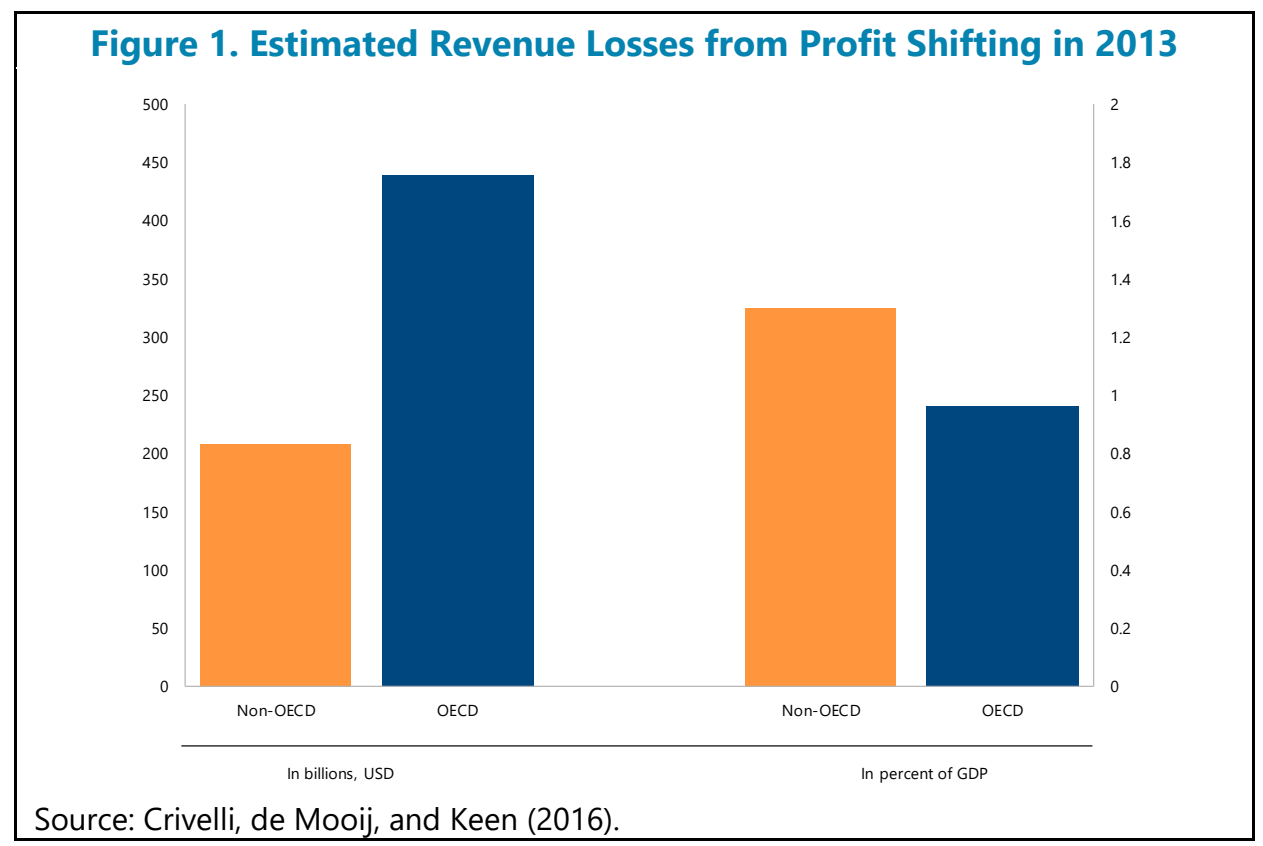

12. While it is too early to tell what impact recent initiatives will have, the scope for profit shifting remains substantial-and unlikely to diminish. The estimates above are 'pre-BEPS.' But significant profit-shifting opportunities still arise-most notably, but not only, in relation to the allocation of risk within multi-national enterprises (MNEs), the valuation of intangibles, and the avoidance or

\footnotetext{
${ }^{13}$ On the drivers of tax uncertainty, and measures to reduce it, see IMF-OECD (2017 and 2018).

${ }^{14}$ Appendix V provides more detail.

15 This reflects quite different methods and requires further examination.
} 
limitation of physical presence. With the increasing importance and salience of complex, intangible-and technology-heavy business models, these difficulties will only increase. One sign that the fundamental drivers of profit shifting have not been fully addressed is an increasing use of essentially arbitrary quantitative limits-such as those under the BEPS interest limitation rules, or even the 10-percent return on tangibles specified in the Tax Cuts and Jobs Act.

\begin{tabular}{|lccc|}
\hline \multicolumn{4}{c}{ Table 1. Estimated Revenue Losses from Profit Shifting for the G-7 } \\
& Clausing (2016) & Beer, de Mooij, and Liu & Tørsløv, Wier, and Zucman \\
& & $(2019)$ & $(2018)$ \\
& & 2015 & 2015 \\
\hline Year of data & 2012 & $\ldots$ & 9 \\
France & $\ldots$ & 6 & 21 \\
Germany & 23 & 2 & 28 \\
Italy & 28 & -6 & 19 \\
Japan & 16 & 3 & 6 \\
United Kingdom & 18 & -12 & 18 \\
United States & $\ldots$ & 15 & 14 \\
\hline Source: IMF staff compilation based on cited papers. & & \\
\hline
\end{tabular}

\section{Tax Competition Continues ${ }^{16}$}

\section{The BEPS project and other recent multilateral initiatives have focused on tax} avoidance rather than what is arguably an even greater concern: tax competition. Such competition is most evident in trends in statutory rates of corporate income tax (CIT) (Figure 2), though it takes other forms too (such as special tax incentives). The consequent revenue losses can plausibly outweigh those from avoidance. OECD (2015e), for example, estimates an overall revenue loss from avoidance of up to 10 percent of corporate income tax revenue; that would be equivalent to a cut in the statutory rate of around 2.5 percentage points ${ }^{17}$-only about half of what has been observed since 2005, making avoidance harder could result in tax competition becoming more intense-particularly for real investments. Whether tax competition is set to intensify remains unclear, though some see the reduction in the U.S. federal corporate income tax rate as likely to stimulate rate cuts elsewhere. ${ }^{18}$

\footnotetext{
${ }^{16}$ Appendix VI elaborates.

${ }^{17}$ Assuming an initial CIT rate of 25 percent, which is around the median for high income countries (Figure 2).

${ }^{18}$ Beer, Klemm and Matheson (2018) suggest possible rate reductions elsewhere of around four points. The GILTI provision, however-acting as a minimum tax - may moderate this, for reasons discussed below.
} 


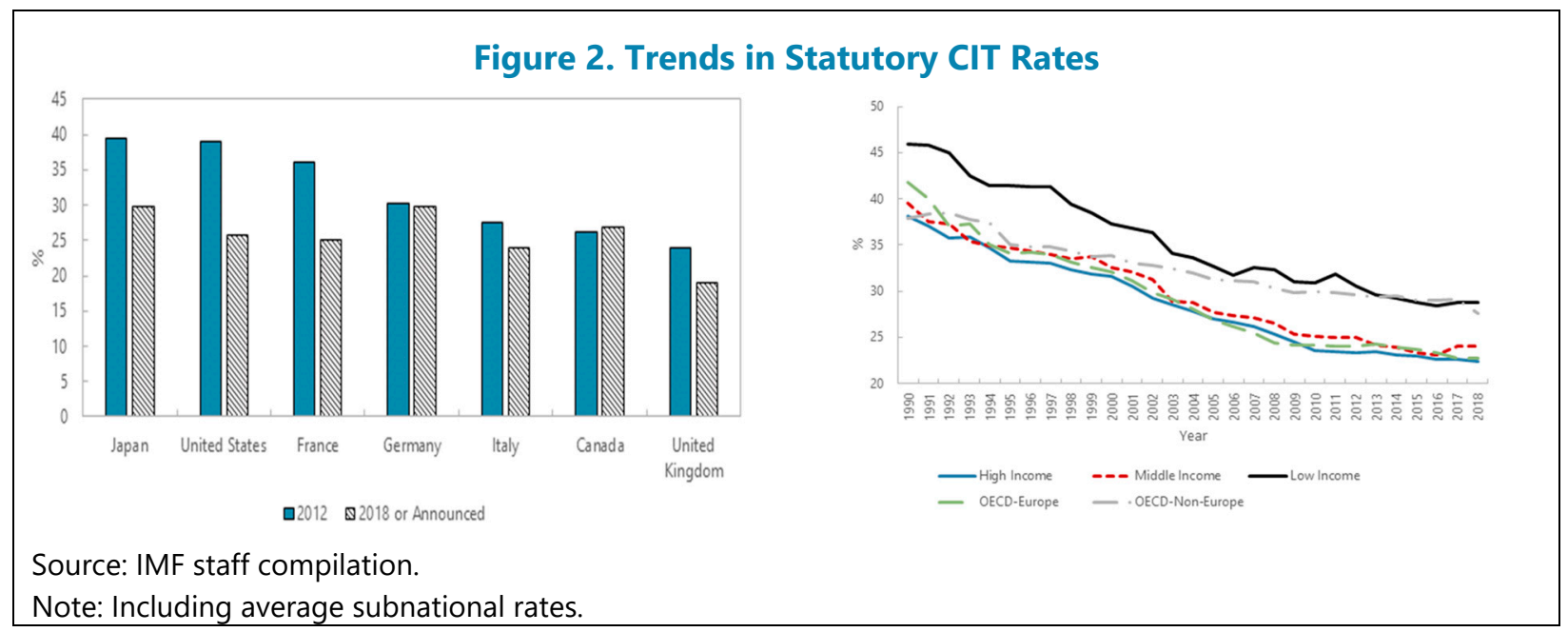

\section{Current initiatives, focused on 'harmful tax practices' (offering preferential tax} treatment to firms without economic substance), ${ }^{19}$ leave some open questions. The recognition that preferential regimes are not necessarily damaging is consistent with developments in thinking over the last decade. Substance requirements, however, bring their own difficulties: potential tax savings may be so large that companies are willing to allocate whatever resources are needed to pass a substance test, however unproductive they truly are in that use; and tax competition becomes focused on attracting real activities. This reflects inherent limitations in addressing tax competition only in the form of specific regimes; it is increasingly recognized that low/zero taxation have adverse spillover effects.

\section{Developing Countries Face Distinct Challenges}

\section{Progress has been made in areas important for developing countries ${ }^{20}$-but} complexity has increased, and profound vulnerabilities remain. ${ }^{21}$ The four areas of particular concern identified in IMF (2014) have received attention since, but remain far from fully resolved (Appendix VII). Given their vast complexity, however, it can be very hard for many developing countries and small states to implement the new global standards and common approaches of the BEPS package, or even to grasp their full implications. This, and dealing with the greater expertise of multi-national enterprises, is a potential drain on scarce talent needed to address what can be more pressing domestic tax issues. Tension arises if countries feel pressured, by the possibility of adverse international "listing", to divert resources to amend practices that likely have little spillover effect or domestic benefit.

\footnotetext{
19 The BEPS minimum standard (OECD (2015c)) and the EU Code of Conduct on Business Taxation (European Council, 1998). 'Substance' means the presence of real functions, indicated for instance by the presence of employees.

20 Meaning low and lower middle-income countries.

21 See also Trepelkov, Tonino, and Halka (2017).
} 


\section{The distinct problems faced by, and capacity limitations of, developing countries} require tailored responses. The main forms of profit shifting affecting them are less sophisticated than those affecting more advanced economies, and tax incentives are an especially prevalent form of tax competition. ${ }^{22}$ While external support can help develop capacity, attention is needed to the rules and norms themselves. Capacity limitations put a premium on the use of simpler methods to protect developing countries' tax bases. Not least, their interests-since they host no major MNEscan be quite different from those of advanced economies. Divergent views are evident, for instance, on source countries' right to tax cross-border service fees.

\section{Digitalization Poses Challenges ${ }^{23}$}

17. Issues raised by digitalization have become a centerpiece of discussions on the future of international corporate taxation. ${ }^{24}$ The context is the increasing use of digital technologies throughout business and the rise of new business models, exemplified by a few well-known firms heavily dependent on digital technologies (Figure 3)-many of them provide a service without charge (though more accurately regarded as a form of barter: access to the service in return for personal information provided in the act of using it). ${ }^{25}$ Many of these firms are highly profitable yet have in many cases paid relatively little tax anywhere. ${ }^{26}$

\section{Two central features widely associated with digitalization-less need for physical presence to do business and, in some business models, unremunerated acquisition of information from customers-are not inherently new. These are not the only tax-relevant} features of the business models often seen as an issue: they also, for instance, have highly valuable intangible assets, creating problems in applying the arm's length principle. But none of these features is qualitatively new or unique. Pharmaceutical companies for instance, also often have significant hard-to-value intangibles. Goods can be exported, and services provided, to a country in which an enterprise has no physical presence-and under current rules this does not create a right for that country to tax the associated profits. Information about customers has long had commercial value, and user contribution-an aspect discussed below-can arise in 'non-digital' contexts.

\footnotetext{
22 Documented and discussed in IMF and others (2015).

${ }^{23}$ Digitalization raises many tax issues beyond those for corporate tax: see Gupta and others (2017) and IMF (2018a).

${ }^{24}$ Digitalization creates some practical issues for the VAT and customs, ensuring for instance that remote sellers remit VAT. But it raises few significant conceptual issues, other than the question sometimes raised of the proper VAT treatment of the barter-like transactions described above.

25 See also European Commission (2014).

${ }^{26}$ It is hard to establish the effective tax rates faced by these companies, but they have likely been substantially increased by the TCJA, both in respect of previously unrepatriated profits and by the 'GILTI' provisions.
} 


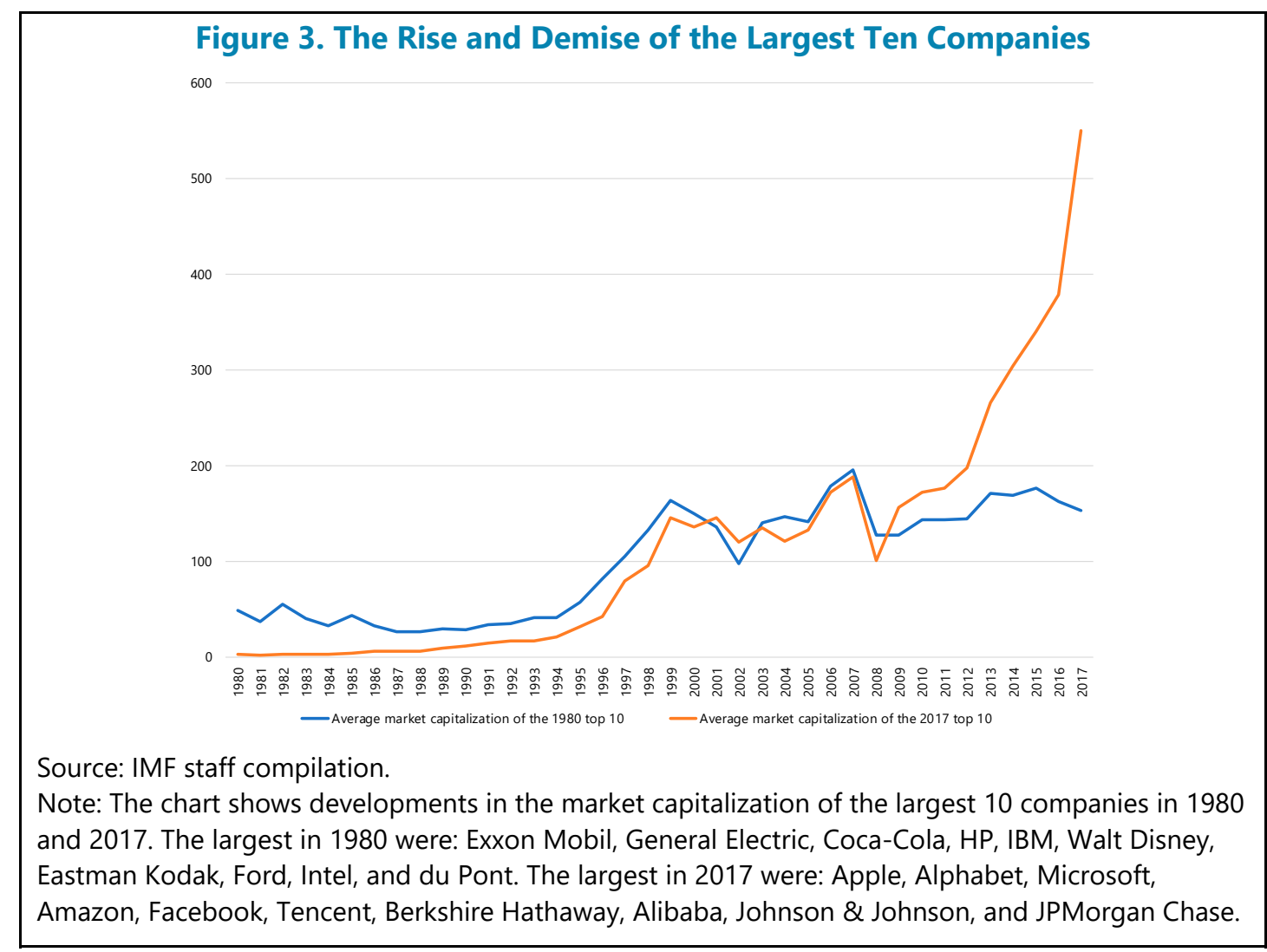

19. They are, however, becoming far more pervasive and salient, suggesting a pragmatic case for action. The functions of delivering goods or intermediating between buyer and seller have become easier to perform remotely, and newer services such as the delivery of online content and operation of social media require little if any physical presence. Whereas much traditional exporting has been business to business, much of this newer business is business to consumer, and hence more salient to consumers whose trust in the fairness of tax arrangements may be undermined by the perception that their government receives little tax from firms so prominent in their daily lives.

\section{THE DIGITALIZATION DEBATE}

20. Dealing with the corporate tax implications of digitalization and new business models is highly contentious, politically and intellectually. If there was any consensus in the initial G-20/OECD report on digitalization, ${ }^{27}$ as in an earlier report by the European Commission (2014), it was that attempts to isolate for special treatment a 'digital economy' (or 'digital activities') are misplaced, given how pervasive these technologies are, and so unpredictable is their future development. The implication was that measures seeking to 'ring-fence' a subset of firms or activities would be inappropriate. However, policy in many countries has moved rapidly in the direction of short-term measures while the search for a common approach continues at the OECD, a final report to the G-20 being due in 2020 .

${ }^{27}$ OECD (2015b). 
21. Views on both the merits of the short-term measures adopted and proposed and the need for fundamental reform to address digitalization differ widely. For some countries, targeted action, pending a longer-term solution, appears to be a political imperative given domestic views of under-taxation; for others, digitalization requires little change in current arrangements. Some see proposed and enacted measures as merely a grab for revenue from a few prominent and largely U.S. owned companies. ${ }^{28}$ Others see the challenges of digitalization point to the need for a fundamental reformulation of international tax arrangements. The principles at stake are profound.

\section{The principal argument used for departing from current norms relates to cases in} which user participation is inherent to the value of the product itself. In this view, ${ }_{1}^{29}$ there are business models in which consumers do not simply derive some satisfaction from the act of consumption but with that act provide some input that is fundamental to the commercial premise of that model. By searching, for instance, they provide information that can shape advertising; by posting on social media, they provide content that attracts other subscribers. Through such 'user participation', they are "co-contributing to a business' offering." 30 This then is seen as a form of productive activity, akin to that traditionally associated with a physical presence, that should create a right to tax in the country of the user but under current rules does not. ${ }^{31}$ Those rules, on this view, therefore need adjustment, accepting this would be a fundamental departure from current norms.

\section{A considerable problem with this approach is how to distinguish cases where users} create value from those in which they just consume. Implementation raises practical issues-in defining precisely when the right to tax arises, and the income that then becomes taxable. These will be hard to resolve without addressing a more fundamental point: so pervasive is the use of (potentially monetizable) information generated by users - that is sent back to the manufacturer by users of motor engines, for example, or of fridges - that drawing the line between cases in which users are and are not contributors is inevitably fraught. This makes attempts to 'ring fence' particular activities in this way highly problematic. While the underlying argument is based on users as generating value, and so akin to a source-based claim, the wider the view taken of contribution, the more the system resembles one that more generally attributes taxing rights to the destination or "market" jurisdiction ${ }^{32}$-a direction of reform explored below.

\section{A quite different (and less prominent) argument rationalizes taxation related to digital business models as targeted to particular sources of location specific rents. ${ }^{33}$ The point is} clearest in relation to the information about themselves that consumers provide when, for instance, they use a search engine. This has meaningful similarities to the extraction of a natural resource:

\footnotetext{
28 See for instance Hufbauer and Lu (2018).

${ }^{29}$ Set out by the European Commission (2018a and b) and HM Treasury (2018a and b).

${ }^{30}$ HM Treasury (2018b), pp. 9.

31 If the users were selling the information about themselves, their earnings would be taxable where they reside; but if they are not explicitly remunerated, those earnings are implicit in those of the firm exploiting the information.

32 Wei (2018) stresses that user value can also be created in countries of 'production'.

${ }^{33}$ See in particular Wei (2018).
} 
information, in this view, is akin to, say, oil. Just as the rents associated with natural resources are seen as a proper object of taxation where they are located, so might be the rents associated with information about a country's residents. The analogy with natural resources is not exact: information is not a rival good, whereas oil is. But there are similarities: both are excludable, both might be seen as collective national assets, and just as the value of crude oil increases as it is refined and processed, the value of raw data increases as it is refined by algorithms and analytics. And critically, both are unique to a particular location. The valuation issues may be greater in relation to information (though they are not always trivial in relation to resources); but this raises issues of practice rather than principle.

\section{Implementing these approaches to taxing income associated with digital-heavy business models would require significant changes to current norms and pose new challenges for administration and compliance, making it an option only for the longer term. It would be} necessary to establish:

- A right to tax even when the multinational group has no resident entity or permanent establishment-some form of 'virtual permanent establishment' ${ }^{34}$ — which requires reformulating double tax agreements. ${ }^{35}$

- Rules for allocating the income to be taxed. The U.K., for example, proposes allocating 'residual profit'-a concept explained further below-partly by the value of user participation. ${ }^{36}$

For implementation (and beyond the need to identify taxpayers without physical presence), the information that may be required (such as the volume of users and appearance of adverts) is not currently collected by tax administrations. Much would need to be self-reported, and administrations may seek some form of third party verification.

\section{In the meantime, several countries have adopted or plan some form of 'Digital} Services Tax'(DST) (Box 1). These vary significantly in detail, but have the common feature of taxing turnover from specified activities rather than income. ${ }^{37}$ This partly reflects the difficulty of identifying associated costs, but also seems intended to keep these taxes beyond the scope of tax treaties. ${ }^{38}$ The 'data as oil' analogy, however, suggests a more positive view of turnover taxation, as

\footnotetext{
${ }^{34}$ The possible nature of such a test for 'significant digital presence' is outlined in European Commission (2018a); similar criteria are in HM Treasury (2018b). Others suggest different criteria: see for instance Schön (2017) and Becker, Englisch, and Schanz (2018). India has introduced a test of "significant economic presence" enabling taxation of non-residents without physical presence (by virtue of sales made to/interactions with Indian consumers).

${ }^{35}$ The recent landmark decision of the U.S. Supreme Court in South Dakota vs. Wayfair Inc. et al may be the shape of things to come: "Modern e-commerce does not align analytically with a test that relies on the sort of physical presence defined [under earlier precedent]".

${ }^{36}$ HM Treasury (2018a) and OECD (2014).

${ }^{37}$ The administrative challenges are similar to those for the longer-term approach just described, but with simpler calculation of the tax base itself.
}

${ }^{38}$ OECD (2018) discusses design features bearing on the consistency of DSTs (or equivalent) with treaty obligations. 
analogous to the royalty that resource countries might wish to impose, whether as an imperfect substitute when direct taxation of rents is difficult, ${ }^{39}$ and/or as a de facto export tax to exercise market power that the individuals about whom information is extracted cannot assert individually.

\section{Box 1. Varieties of Digital Services Tax}

Prominent examples of actual/proposed DSTs are described in Appendix VIII. Key differences include:

The EU and U.K. proposals have similar scope-focused on social media, search engines and intermediation services-but take different approaches to measuring user value. The EU takes a volume-based approach, allocating revenue in proportion to how often an advert has appeared on users' devices and the number of users having concluded transactions on a particular platform, with the location of the user determined based on their internet protocol (IP address). The U.K. in contrast envisages a value-based approach, looking for example to the value of the advertising sales targeted at U.K. users, and the commissions generated by facilitating a transaction with U.K. users. Questions remain as to how the definition of the user would determine the apportionment of revenue from cross-border transactions, and how to apportion revenue derived from the sale of multinational data sets.

Other countries (including India, Chile and Uruguay) have opted for withholding or 'equalization' taxes on payments for advertising and other specified digital services made by residents to non-resident companies, avoiding the need to apportion revenue attributable to domestic users. Simpler to design and administer, such taxes risk avoidance by having related offshore entities purchase the services.

Some low-income countries (Benin, Tanzania, Uganda, and Zambia) have recently introduced taxes on the use of certain digital services, though these are taxes not on the revenues of service providers but on access to digital services, such as social media.

27. The efficiency effects of digital services taxes are not clear cut. The digital service tax looks like a simple turnover tax, likely to be passed on to some degree in the price of the taxed service. If the service, such as advertising, is itself used as business input then this becomes a potential source of production inefficiency. ${ }^{40}$ However there are significant qualifications to this: (1) If the marginal cost of providing the taxed service is low, then the digital services tax acts like a tax on the firm's quasi-rents: rents that are exclusive of costs sunk in establishing the business. The primary impact may then be not on current pricing but on future investment; (2) The user participation test means that the digital services tax applies in contexts with features of 'two-sided markets' in which incidence effects are complex..$^{41}$ While the potential revenue from digital services taxes is significant, their efficiency effects remain unclear.

\footnotetext{
${ }^{39}$ In the extractives context, Boadway and Keen (2010) show that some royalty may be desirable if rent taxation is vulnerable to cost-based profit shifting.

40 To the extent that they reduce any tax-induced competitive edge foreign suppliers may enjoy over domestic (of advertising targeted at domestic consumers, for instance) equalizing treatment between domestic and foreign suppliers that will ease a production inefficiency.

${ }^{41}$ Firms may aim to shift some burden to the untaxed side: a tax on advertising creates an incentive to raise the price charged (or reduce the subsidy provided) to users; the price of advertising services may even fall. On tax incidence in two sided-markets, see Bourreau, Caillaud, and De Nijs (2016) and Kind, Koethenburger, and Schjelderup (2008 and 2010). A further consideration arises from the likelihood that using social media by final consumers is complementary with leisure: which, on efficiency grounds, calls for relatively high taxation.
} 
28. Political pressures to introduce some form of digital service tax are strong in many countries-but their uncoordinated proliferation creates complexity and jeopardizes tax cooperation. Practitioners stress the compliance costs associated with divergences between the emerging DSTs; the potential scope for disputes in identifying taxable activities; and the risk of double taxation. What is evident and troubling, in any case is that the divergent approaches mark a major departure from the incomplete but significant progress that the BEPS project has made in taking forward thoughtful multilateralism in international tax matters.

29. The digitalization debate is emblematic of wider difficulties with the international tax system, and its importance is largely in suggesting a need for more thoroughgoing reforms. It shows that, while the general principle that tax be levied where value is created readily attracts agreement, views can differ widely when it comes to deciding where exactly that is, the difficulty being especially apparent for, but not limited to, digital business models. It is one which as is increasingly widely acknowledged the arm's length principle does not fully resolve. None of the proposed solutions to the perceived problems from digitalization would deal with profit shifting and tax competition.

\section{ALTERNATIVE ARCHITECTURES}

30. So fundamental are the challenges to the current international tax system that alternative futures are now widely discussed-by policy makers, as well as academics and civil society. After setting out criteria for doing so, this section evaluates four main alternative international tax architectures.

\section{A. Evaluating Alternative International Tax Systems}

31. The BEPS objective of "taxing where value is created" 42 is at best an incomplete standard by which to assess international tax arrangements. There are circumstances of tax planning in which it may be widely agreed that no value is being created. Beyond that however, the phrase is far from providing the practical guidance needed to answer all questions: the digitalization debate, as seen above, is only the most clear-cut instance in which there is evidently no agreement on where value is created. More fundamentally, whenever value is the product of several contributions, there is no unambiguous way to express that value as the sum of distinct contributions. ${ }^{43}$ This objective also falls short as a standard of efficiency: if the place in which value is created can be changed, it leaves open the possibility of distortions arising from differences in tax treatment and of collectively damaging competition to attract the 'value-creating' activities. There is

\footnotetext{
42 Schön (2017), pp. 5 describes this as a "new mantra".

${ }^{43}$ Grinberg (2018, pp. 19) summarizes: "the consensus academic view is that any exercise to define specific sources of value creation is entirely subjective".
} 
danger, moreover, that testing for value creation by the presence of production factors will lead to the unproductive allocation of resources in search of tax savings.

\section{Efficiency requires that rents-receipts above the minimum return required by the} investor-be taxed somewhere. Rents are an attractive tax base because they can be taxed without distorting behavior: that is, without creating excess burden. Taxing rents has no impact on investment for instance, and (since all costs of finance are deductible ${ }^{44}$ ) it eliminates problems of both 'debt-shifting' (the use of intra-group loans to reduce lability) and 'debt-bias' (the incentive to use third party debt, with significant risk to financial stability). ${ }^{45}$ Implementing rent taxes, however, is not straightforward, partly because some costs (managerial effort, for instance) are hard to observe and to provide deductions for. Moreover, many sources of rent-related to company-specific knowhow, for instance-could be generated from alternative locations, so cannot be taxed without fear of driving their generation elsewhere. There are some rents, however, specific to particular locations; most obviously those associated with natural resources; deploying rent taxes in the extractive industries is a standard IMF recommendation. ${ }^{46}$ Even with location specific rents, however, the practical difficulty arises that standard avoidance techniques can be used to relocate their apparent source across jurisdictions.

\section{There are, however, few other robust principles for efficient international tax design, ${ }^{47}$} leading to a more pragmatic focus on identifying particular distortions. Various dimensions of desirable tax neutrality can be identified: between alternative locations for outward investment (capital export neutrality (CEN)), alternative sources of inward investment (capital import neutrality $(\mathrm{CIN})$ ), and in the ownership of domestic assets (capital ownership neutrality (CON)). But it is impossible to ensure all three without fully harmonized tax systems, and failing that, there are no clear-cut results on the relative importance of each. Attention thus focuses more pragmatically on specific signs of tax considerations dominating commercial ones or distorting competition.

\section{There is even less agreement on standards of inter-nation equity-other perhaps than} the allocation of taxing rights over location specific rents to the jurisdictions in which they arise. The case for allocating taxing rights over location specific rents to the location country seems widely accepted - though putting this concept into legal language is challenging. It will, in any event, be taken as given in what follows that source countries are to retain substantial taxing rights in relation to natural resources. Beyond this, however, is a longstanding tussle for taxing rights between 'source' and 'residence' countries-a critical issue for low income countries, which are primarily 'source' countries. These two categories, however, are increasingly blurred, as it becomes harder to tie down where profits are created and as corporate residence becomes increasingly removed from economic fundamentals: corporate structures can be arranged to establish residence

\footnotetext{
44 Though different forms of rent tax achieve this is different ways, as will be seen.

45 See IMF (2009) and IMF (2018b).

46 IMF (2012).

${ }^{47}$ See Appendix VII of IMF (2014).
} 
in a place advantageous for investment in third countries; and the residence of the parent company-which can be, and often is, changed if the tax savings become large enough-is an increasingly poor proxy for the residence of its shareholders. ${ }^{48}$

\section{Critical concerns with any international tax arrangements are their vulnerability to} profit shifting and tax competition, touching on both inter-nation equity and efficiency. The spillovers these can generate relate most evidently to inter-nation equity, through their impact on the allocation of tax revenues across jurisdictions. Both raise efficiency concerns too. Companies may, for instance, move real resources inefficiently in order to exploit profit shifting opportunities. There is potential inefficiency too in terms of governments' financing decisions: by reducing tax revenue, these spillovers ultimately create a need to either deploy other tax instruments that are more distorting (or inequitable) or cut public spending.

\section{The importance of the corporate income tax to low income countries and their greater} vulnerability to profit shifting warrants special attention. Lower income countries tend to be somewhat more reliant on the corporate income tax as a source of revenue than are other countries (Figure 4). Moreover, any reduction in their corporate income tax revenue may be hard to replace: of their main revenue sources, the VAT in many cases is already under stress, the personal income tax remains weak and reliance on trade taxes is already high.

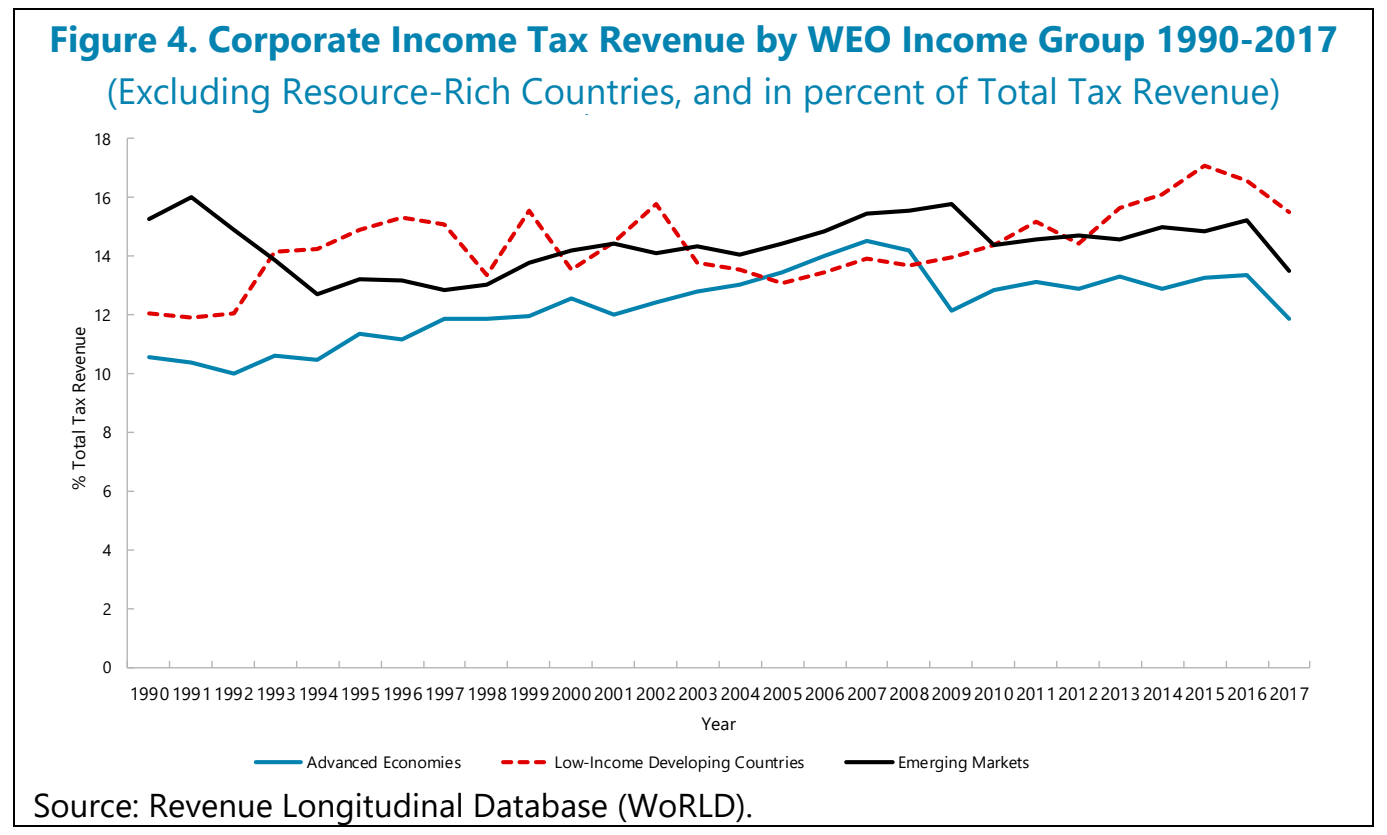

37. Ease of administration and compliance are key concerns, and closely related to assuring certainty in tax matters. The considerations here are broadly as in other areas of taxation, including for example, the simplicity and clarity of obligations, the scope for self-assessment, the ability to identify taxpayers, and the ease of verification and enforcement.

\footnotetext{
${ }^{48}$ For instance, about 54 percent of U.K. shares and 35 percent of US shares were held by foreigners at end 2016 (Office of National Statistics and Rosenthal (2017)).
} 
38. Legal commitments can also affect the viability of proposed reforms, whether in the nature of hard law of (in particular) double tax agreements, WTO rules, and EU law, or softer rules such as BEPS minimum standards and other agreements.

39. The evaluation of a scheme may be quite different depending on whether its adoption is multilateral or unilateral. It will be seen below, for example, that there are schemes that eliminate profit shifting if adopted globally but exacerbate it if adopted unilaterally. And multilateral adoption would imply some consensus on the need to overcome legal obstacles.

40. Though not among the criteria, how schemes affect national tax revenues is of evident interest in shaping the debate. The accounts that follow thus also present such (often limited) evidence on this as there is.

\section{B. Minimum Tax Schemes}

41. "Minimum taxation" refers here to schemes ensuring that profits are subject to some minimal level of taxation ${ }^{49}$-and so target, primarily, profit shifting. These can apply to outbound and/or inbound foreign direct investment; both are envisaged in a proposal by France and Germany. ${ }^{50}$

\section{Minimum Taxation of Outbound Investment}

42. Minimum (residence-based) taxation of outbound investment has long existed in the controlled foreign company (CFC) rules of many developed countries-for which both BEPS and the EU Anti-Tax Avoidance Directive (ATAD) envisage a heightened role. These rules vary widely, the common feature being that some types of income earned by foreign subsidiaries ${ }^{51}$ are taxed immediately to the parent, rather than only on remittance through dividend payouts (generally with credit for foreign taxes paid). BEPS Action 3 recommends the adoption of controlled foreign corporation rules, and makes design recommendations ${ }^{52}$ (but does not set any minimum standard), with application when effective tax rates are "meaningfully lower" than those applying to the parent. The anti-tax avoidance directive mandates a controlled foreign corporation rule which tests the difference between tax paid and that which would be paid in the EU member state of the parent.

\section{Under a worldwide tax system, controlled foreign corporation rules are essentially an} anti-deferral device. They ensure that tax is not deferred by retaining profits in foreign subsidiaries subject to low or no tax.

\footnotetext{
49 This is distinct, for instance, from agreement on minimum statutory tax rates.

${ }^{50}$ Franco-German joint declaration on the taxation of digital companies and minimum taxation (December 2018). On taxes of the kind discussed here, see also Grinberg (2018).

51 Some countries apply such rules only to corporations; others include ownership by individuals as well.

52 OECD (2015b).
} 
44. The move toward territorial taxation in almost all advanced economies strengthens the case for some form of minimum taxation on foreign earnings. Territoriality means that active business income earned in foreign subsidiaries (sometimes also permanent establishments) is taxed only by the source country. This creates an incentive to make domestic income appear to arise in low tax jurisdictions abroad, and so escape taxation at home. Charging some minimum tax on income from abroad can then provide a backstop, without which territoriality can jeopardize domestic taxation.

45. The U.S. "Global Intangible Low Taxed Income" (GILTI) tax, introduced by the Tax Cuts and Jobs Act, is a minimum tax on outbound foreign direct investment returns (Appendix IV). A principal rationale was to minimize the opportunity, heightened by moving to territoriality, to shift intangible assets and their associated income to lower taxed jurisdictions abroad. It imposes a U.S. minimum tax on the defined term "global intangible low taxed income"-profits above a 10 percent deemed return on tangible assets located abroad-at 10.5 percent (if no tax is paid abroad), with U.S. liability wholly eliminated if the foreign tax on that income exceeds 13.125 percent. One estimate is that this provision will increase U.S. corporate income tax revenue by about USD 8 billion. ${ }^{53}$ The structure of and incentives created by the global intangible low taxed income tax are complex, ${ }^{54}$ but this new approach has heightened awareness of the potential benefits of effective minimum taxation of outward investment.

46. Variants of this approach can be envisaged. Rather than testing by reference to tangible assets, one might simply tax any income of foreign branches or subsidiaries regarded as insufficiently taxed; ${ }^{55}$ and the test might be applied country-by-country to eliminate avoidance by pooling income across high and low-tax foreign jurisdictions.

47. The spillover effects of minimum taxes on outbound investment are broadly positive, including reduced pressures on source countries to engage in tax competition. In effect, they strengthen an element of worldwide taxation ${ }^{56}$ in a world with increasingly territorial systems. For higher tax countries, they protect against low taxes abroad by reducing their benefit to the investor. By the same token, however, they reduce the benefit to source countries of offering those low tax rates. Minimum taxes on outbound investment can thus have a strategic effect of limiting the aggressiveness of tax competition, which can be of benefit to those source countries themselves as well as others. Any such induced increase in effective tax rates in low tax and source countries may then also indirectly benefit other high tax countries. One risk of strengthening residence-based taxation in this way, however, is a possible inducement to 'invert': that is, relocate the parent

\footnotetext{
53 Clausing (2018a).

54 See for instance Dharmapala (2018) and Chalk, Keen, and Perry (2018).

55 For EU members, inclusion of domestic subsidiaries would be required.

56 This was one of the reform options considered in IMF (2014).
} 
company to jurisdictions not imposing such a charge. ${ }^{57}$ The TCJA includes stern measures to discourage this; common adoption would alleviate the problem.

48. The diminished scope for profit shifting simplifies administration and compliance, and legal impediments are modest. There are complexities for tax authorities: for instance, in identifying tax paid abroad, and verifying that it is not refunded or credited against some other tax; and effective exchange of information arrangements will become even more critical. But these have proved manageable. The approach can be designed to be consistent with current norms (including double taxation agreements), with required domestic law changes capable of leveraging off existing controlled foreign corporation rules-though a common design approach would be preferable to reduce complexities and compliance burdens.

49. An important design issue is the rate at which the minimum would be set. The GILTI provision, for example, sets a minimum at half the domestic rate. Setting a minimum below the domestic rate in this way reduces, but does not remove, a potential distortion favoring investment abroad. Charging earnings abroad at the domestic rate-establishing a pure worldwide system without deferral-would be consistent with the principle of capital export neutrality. Setting a lower rate is to some degree a compromise with principles of capital import neutrality and capital ownership neutrality, leaving a substantial role for the source country rate in anchoring the final tax paid by investors from all countries. Without the theoretical guidance between these principles suggest a compromise may have merit but leaves open precisely where the balance is best struck.

\section{Minimum Taxation of Inbound Investment}

\section{The Base Erosion Anti-Abuse Tax (BEAT) of the Tax Cuts and Jobs Act is a minimum} tax on inbound investment-and a blunt one. Companies resident in the U.S. pay whichever is greater: (1) Their liabilities under normal rules or, (2) Tax charged at a lower rate but on a base that differs from the normal base in not allowing deductions for items (such as interest, royalties, and management fees) paid to related parties abroad that are commonly associated with profit shifting. ${ }^{58}$ The latter element thus sets a minimum charge that limits the extent to which the tax base can be eroded by such payments. The BEAT goes much further than the BEPS actions on transfer pricing and interest stripping, applies regardless of the rate of tax applicable in the foreign country on receipt of the payments in question, and applies to a broad range of payments. As with the GILTI, so too the base erosion anti-abuse tax has prompted wider interest in schemes of broadly the same kind.

51. Less blunt alternatives can be crafted, notably by denying a deduction for certain payments made to related parties or removing the entitlement to treaty benefits unless the taxpayer can demonstrate that those payments were subject to a minimum effective tax rate abroad. ${ }^{59}$

\footnotetext{
57 This can itself stoke tax competition, Clausing (2018b).

58 More detail is in Appendix IV.

59 Implementing such a test-which could be defined in various ways—could be complex and would need underpinning by effective EOI arrangements.
} 
Implementation is harder if the minimum is conditional on tax paid abroad, though the legal issues are more navigable. The former is likely a price worth paying to limit distortions (at least for developed countries). The latter requires consistency with current norms, such as those on nondiscrimination (meaning provisions should apply equally to like domestic transactions). And where implemented as a residence-based measure, this can be designed consistent with existing DTAs.

52. Effective though such rules can be, they have an inevitable element of arbitrariness. In taking the nature of some payment as a proxy for its potential abusiveness, they risk capturing genuine business transactions and so cut through rather than resolve those vulnerabilities. This arbitrariness may, nonetheless, be a price worth paying for resolving prominent difficulties while avoiding the need for more thoroughgoing reshaping of the international tax order.

\section{Minimum Taxes for Low Income Countries}

\section{For low income countries, simple measures protecting against base erosion on} inbound investment can play a critical role-as part of the core system, not an alternative minimum. Few substantial multi-national enterprises are headquartered in low income countries, but many multi-national enterprises operate there-making inbound rules of the essence, with simplicity the key to effectiveness in an environment of constrained capacity. This calls for straightforward measures of base protection as part of the core system, combined with the minimum taxes (directed mainly at domestic avoidance and evasion) that many developing countries already have-and which are often recommended in IMF technical assistance. ${ }^{60}$

54. One approach is to cap the deductibility of certain expenses to related parties. Many low income countries have provisions of this kind: Côte d'Ivoire, for instance, denies intragroup royalty payments and service fees exceeding 5 percent of turnover.

\section{A broader rule denying local deductions for base-eroding payments not subject to} minimum effective taxation in the hands of the recipient can be appealing for low income countries. Details (relating to carry forward, for instance), could naturally vary with countries' circumstances; and placing the onus on the taxpayer to prove that adequate tax is paid by the recipient is even more important in the low income country context. Rules of this kind could be designed to be consistent with existing double tax agreements. A similar function could be served through final withholding taxes at relatively high rates, but the ability to impose these could be constrained by existing double tax agreements, unless amended or overridden. That could mean: (i) Not offering reductions in withholding rates under applicable double tax treaties; and/or (ii) Imposing withholding on certain payments to which they have not traditionally applied. An example of the latter is found in the new UN model treaty provision that would permit withholding on cross border payments for technical services.

\footnotetext{
${ }^{60}$ In Latin America, these minimum taxes are often based on gross or net assets; in sub-Saharan Africa, they are commonly based on turnover. Best and others (2015) analyze the impact and merits of such a scheme in Pakistan.
} 
56. A more substantive issue for low income countries is whether such an approach might be used as well as conventional transfer pricing, with possible expansion to cost of goods sold. ${ }^{61}$ Use is also sometimes made of optional "safe harbors": publicly set minimum profit margins for defined sets of transactions, which are deemed to comply with the arm's length principle. Taxpayers do not need to produce a transfer pricing study, nor search for comparable market transactions; they simply need to show a profit margin for qualifying transactions to fall within the safe harbor level. The key for a successful safe harbor is that it targets homogeneous and relatively simple transactions and the minimum profit margin is not set to be a tax benefit.

\section{Such a rule could be combined with a "residual profit split" method, of the kind} discussed below. For example, a regime of denying deduction for some cross-border payments made for the use of inputs within low income countries could be related to requiring a "normal" return to those inputs to be taxable there.

58. Possible adverse effects on investment need to be borne in mind, and might be eased by some coordination in adoption. Blunter tools ease administration, but run a greater risk of impeding legitimate payments and discouraging investment. Countries that adopt such measures unilaterally may consequently make themselves more exposed to competition from jurisdictions that do not adopt them. Coordinated adoption could help limit the risk, that each country might see in acting alone, of diverting investment elsewhere.

Summary Evaluation: Minimum tax schemes can be powerful in addressing profit shifting, and can dampen tax competition. They face relatively modest legal impediments, though administration can be complex. On inbound investment, they can be especially appealing for lower income countries.

\section{Border-Adjusted Profit Taxes}

59. Several alternative architectures involve some element of 'destination-based taxation': the allocation of some taxing rights to the jurisdiction in which the purchaser is located. ${ }^{62}$ No such taxing rights are allowed under current norms, and their possibility was barely considered before the U.S. House proposal mentioned above. Now they are part of the policy debate, with shades of destination-based taxation evident in recent developments. The Tax Cuts and Jobs Act, for example, applies a reduced rate to export earnings and limits some deductions for payments abroad. And the notion of user participation as creating a taxing right, though conceptually quite distinct, in practice allocates some taxing rights to jurisdictions in which final users of a product are located. Indeed, and though doubtless unintended, the call to tax where value is created might seem to imply some taxing rights in the destination country since there is no value without buyers.

\footnotetext{
${ }^{61}$ Measures affecting trade in goods also need to be carefully designed with regard to applicable WTO rules.

62 Destination rules might follow the principles of the OECD's International VAT/GST Guidelines.
} 
60. Border adjusted profit taxes are a special form of destination-based taxation, marked by the exclusion of exports from the tax base and the inclusion of imports. ${ }^{63}$ In this respect they are just like the VAT, which excludes exports from tax by zero-rating them ${ }^{64}$ and fully taxes all imports; the key difference is that labor costs are deducible under a border adjusted profit tax, but not under the VAT. (Destination taxation, it should be noted, can take forms other than border adjustment, such as the use of sales as one factor in allocating a multi-national enterprise's overall profit, as discussed below).

\section{The Destination-Based Cash-Flow Tax}

61. The Destination-Based Cash Flow Tax (DBCFT) ${ }^{65}$ combines border adjustment with 'cash flow' treatment (that is, immediate expensing of investment without deduction of interest). In a closed economy, cash flow taxation means that the government takes a share of all receipts and (by allowing them to be fully deductible) bears the same share of all costs. The government only raises revenue, in present value, to the extent that returns are above normal: the tax thus falls only on rents. ${ }^{66}$ Destination basing ensures that the same applies in an open economy. Receipts and expenses may then arise in different jurisdictions. Suppose, for instance, that exports from the home country are taxed in the destination country at a higher rate than costs are deducted at home. It might seem that investment at home will be discouraged. If these taxes are applied generally, however, prices and/or the exchange rate can adjust so as to offset this effect. A depreciation of the home currency (or increased prices abroad) can ensure that net receipts in domestic currency are unaffected by the difference in tax rates, ${ }^{67}$ and investment decisions will be undistorted. Complexities arise in relation to financial flows, especially across borders: broadly, destination- based cash flow tax proposals envisage disregarding them. ${ }^{68}$ Being a rent tax, the destination-based cash flow tax leaves both investment and finance decisions undistorted: debt bias, for instance, is eliminated. ${ }^{69}$

\section{The DBCFT is equivalent to a broad-based single rate VAT combined with a wage} subsidy at the same rate. Movement towards a DBCFT thus has similarities to increasing the VAT rate while reducing wage taxes. Conversely, the demise of the traditional CIT and increased reliance

\footnotetext{
63 For business purchasers, imports might either be taxed but deductible or simply non-deductible.

64 That is, providing full refund for any taxes paid on inputs

65 Proposed by Bond and Devereux (2002), further detail is in Auerbach and others (2017a), and an analytical treatment in Auerbach and Devereux (2018).

${ }^{66}$ Cash flow taxation could also be introduced without shifting to a destination base, but tax competition pressures countries toward lower tax rates.

67 Table 2 of Auerbach and others (2017a) illustrates the point. To see why domestic prices and/or the exchange rate are expected to respond to adoption of a DBCFT, note that, levied at rate $\tau$, border adjustment acts to raise the price of imports purchased by final consumers by the factor $(1+\tau)$; this can be offset, and relative prices left undisturbed, if domestic prices and wages rise by the same factor or the currency appreciates by the proportion $\tau /(1+\tau)$.

68 See Auerbach and others (2017).

${ }^{69}$ Here as elsewhere, we abstract from possible distortions through personal taxation.
} 
on the VAT combined with a reticence to raise wage taxes-a direction in which many countries have been heading ${ }^{70}$ — has similarities to moving towards a DBCFT, but with the important difference that real-world VATs are far from the single rate/broad base of an idealized DBCFT.

\section{The incidence of a DBCFT would fall largely on recipients of rents in the adopting} country. If adjustment takes the form of an increase in domestic prices and wages, non-residents are wholly unaffected, so the burden falls on domestic rent recipients and those on fixed nominal incomes. If adjustment is in the form of an appreciation of the adopter's currency, domestic wage earners are again unaffected; while non-residents receiving rent income generated by activities in the adopting country gain an increase in receipts in their home currency, this offsets the tax paid.

64. Adoption of a DBCFT (even unilateral) is not expected to affect trade. Unlike a tariff, a DBCFT does not create a preference for domestic production over imports: all sales to final consumers, imported or domestically produced, are taxed, and all domestic costs are deductible whether used to produce for exports or for the domestic market. In a frictionless world, changes in the real exchange rate immediately undo the border adjustment. In practice, sticky prices and/or pricing in the currency of a DBCFT-adopting country would mean slower adjustment, but the effects are expected to be small and fairly brief. ${ }^{71}$

\section{Turning to evaluation, the principal and substantial merits of the DBCFT are that, adopted universally, it would largely eliminate both profit shifting and tax competition:}

- Since both exports and imports for business use are excluded when calculating the tax base-in every country, with universal adoption-manipulating the apparent prices of such transactions does not affect tax liability. With financial flows excluded from the base, opportunities for debt shifting also vanish. ${ }^{72}$

- Tax liability under the destination-based cash flow tax ultimately turns only on the treatment of the sale to final consumers: tax on intermediate transactions ultimately does not 'stick,' since the purchase is deductible for the buyer. And to the extent that the location of the final consumer is fixed (people being relatively immobile) there is no scope for seeking to attract tax base or the activities that generate it.

Just as profit shifting and tax competition are minor issues under the $\mathrm{VAT}^{73}$ so they are expected to be under a destination-based cash flow tax.

\footnotetext{
70 Levels of and changes in statutory CIT and standard VAT rates have indeed been negatively correlated.

71 See Auerbach and others (2017a) and Buiter (2017). Barbiero and others (2018) show in a DSGE model that, while there is no impact under local currency pricing, under U.S. dollar pricing DBCFT adoption by the U.S. would depress exports and imports by up to 0.3 percent, though the impact would largely expire after 10 quarters.

72 Auerbach and others (2017b) elaborate.

${ }^{73}$ Except in the case of cross-border shopping when indirect tax rates vary widely and for small high-value items.
} 


\section{Adoption by only a subset of countries, however, could put intense pressures on} others. If only some countries adopt a destination-based cash flow tax, those maintaining an originbased system would experience dramatically increased incentives for outward profit-shifting, since any profit shifted to a destination-based cash flow tax country would face a tax rate of zero. Matching adoption of a destination-based cash flow tax is one possible response, though not necessarily the best as that foregoes the opportunity to extract revenue from non-residents. The potentially large shifts in exchange rates could also strongly affect international investment positions of other countries, depending on their currency composition.

\section{For resource-rich countries, a destination-based cash flow tax-and destination taxation more generally-should be supplemented by source-based taxes focused on} capturing any location specific rents. The incidence of the destination-based cash flow tax is on domestic residents, and the likelihood of trade surpluses, and hence revenue losses, is much higher in resource-intensive countries. For resource-based (and other) location specific rents, origin-based taxation is in principle efficient (albeit subject to implementation challenges) and can moreover extract revenue from nonresidents. This need not though impede destination-based cash flow tax adoption: rent taxes and other charges common in the extractive industries could be raised to compensate for any revenue shortfall, though the sector will then continue to face pressures from profit shifting.

\section{Recent estimates ${ }^{74}$ suggest that, at unchanged tax rates, global DBCFT adoption would} mean significant short-term changes in national tax revenues (Figure 5), with little change of the overall level.

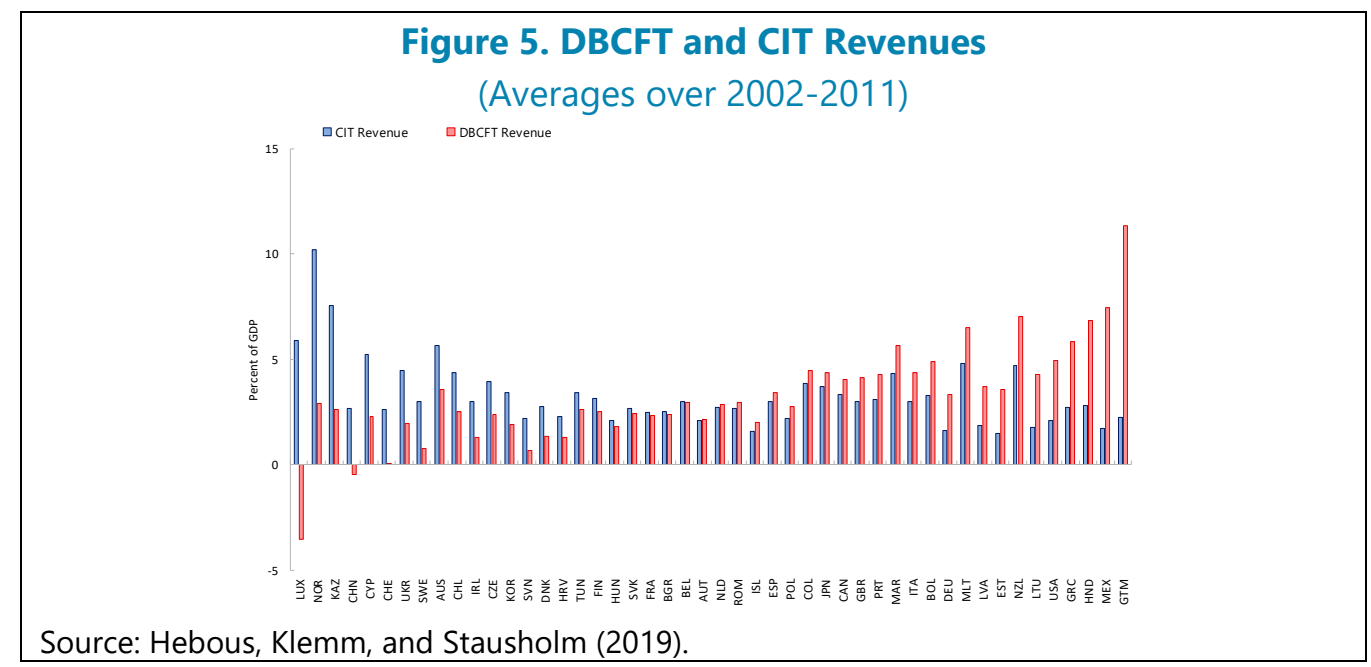

69. Figure 6 illustrates characteristics associated with greater likelihood of a short-term revenue gain from global adoption. ${ }^{75}$ Reflecting an impact driven more by destination-basing than by cash flow taxation, these include:

\footnotetext{
74 The results presented in this section are from Hebous, Klemm, and Stausholm (2019).

${ }^{75}$ Each of these factors proves significant controlling for the others, though somewhat less so for income per capita.
} 
- Trade deficits: With imports taxed under the destination-based cash flow tax and exports exempt, trade deficits are associated with higher revenue.

\section{- Limited resource revenues.}

- Low per capita income: This is surprising-one might have expected such countries to lose, given their role as locations of production — but may reflect extensive avoidance under the current system (the destination-based cash flow tax estimates assume full compliance).

\section{These short-term effects may however be reversed over time, and/or offset by}

changing the tax rate. Intertemporally, the effects may become smaller as trade balances adjust: to the extent that trade balances over time, the revenue effect, in present value, is zero. Countries with large positive initial international investment positions, on the other hand, which can finance future trade deficits could gain in the long term (Auerbach, 2017). Even leaving that aside, the absence of pressures from profit shifting and tax competition under a DBCFT mean that the rate of tax can be adjusted as need be to maintain revenue without fear of adverse effect through those routes.

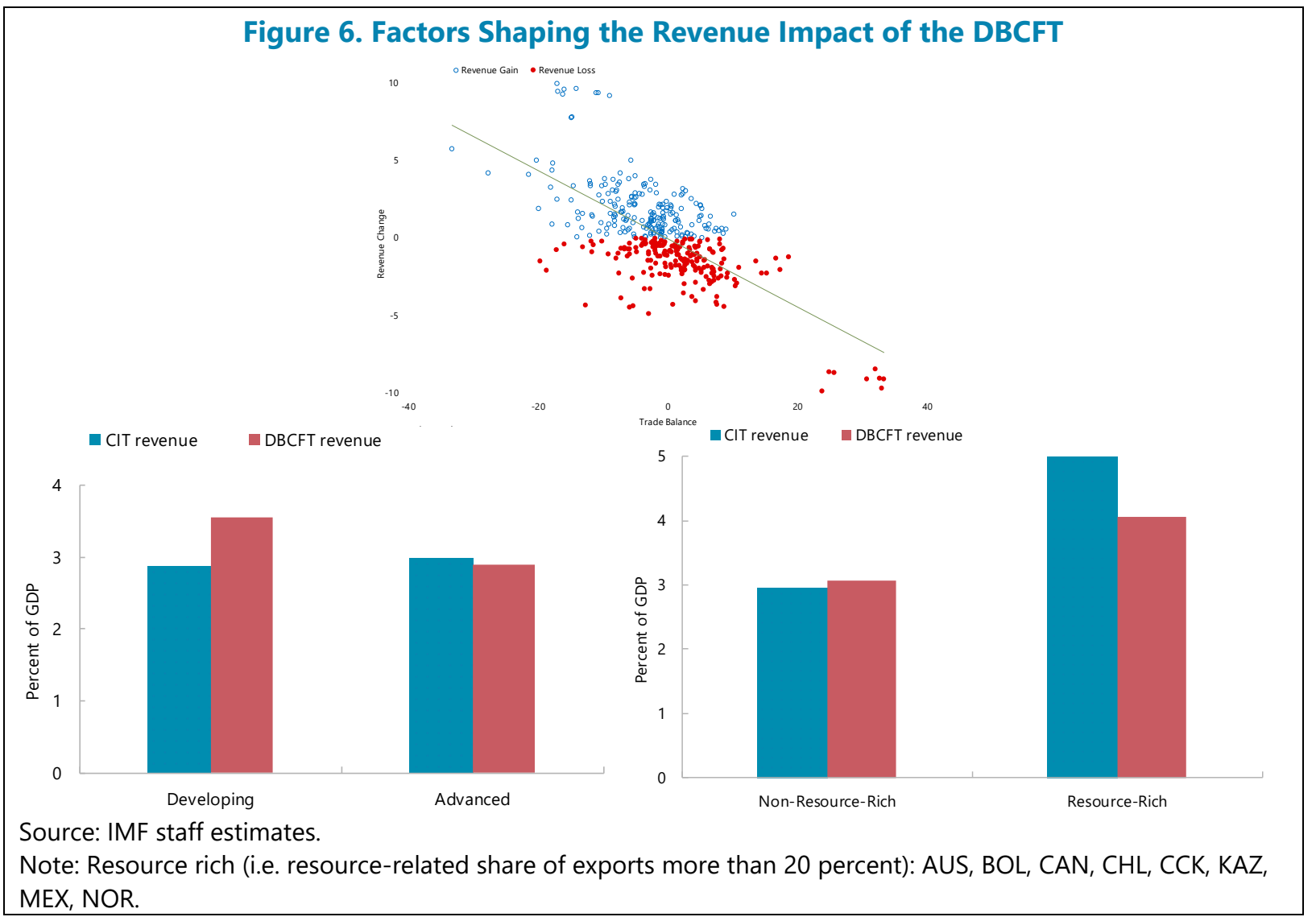

71. The adverse spillovers from unilateral adoption of the DBCFT could be large, while global adoption could be difficult to agree on given major redistribution of revenues. Hebous, Klemm, and Stausholm (2019) estimate that adoption by a large integrated economy such as the U.S. could cause neighboring countries to lose about 40 percent of their tax revenue from multi- 
national enterprises. Multilateral adoption could limit these spillovers, but the potentially large changes in national tax revenues create their own obstacles to global adoption.

72. Implementing a DBCFT would be relatively straightforward, the primary issues arising in relation to refunds. Almost all tax administrations are familiar with border adjustment through the VAT (though implementation under the destination-based cash flow tax-on the basis of accounts rather than invoices-would be different) ${ }_{i}^{76}$ and deduction of wage costs is standard. Difficulties would arise in identifying and bringing into tax sellers with no physical presence (mainly for business to consumer business) — but so they increasingly do under the VAT. ${ }^{77}$ The deductibility of wages, however, means that refunds would be more prevalent than under the VAT, amplifying the challenge of protecting against fraud while ensuring prompt payment to honest businesses.

\section{There are significant legal issues associated with the destination-based cash flow tax} potential inconsistencies arising with:

- WTO rules - despite its being economically equivalent to a VAT plus wage subsidy, each of which is WTO-compatible. Views differ on whether a destination-based cash flow tax could be drafted to avoid this risk. ${ }^{78}$

- Double taxation agreements - which absent physical presence do not allocate any taxing rights to the country of the final sale. If the destination-based cash flow tax were held to be within their scope, double taxation agreements would need amending.

74. This fundamental treaty issue arises for any scheme creating an inherent liability to profit taxation in the country of final sale-as several of the options discussed below do.

\section{A Destination-Based Allowance for Corporate Equity/Capital (DBACE)}

\section{A Destination Based Allowance for Corporate Equity (DBACE) faces fewer transitional} issues than the destination-based cash flow tax but might be less effective at preventing profit shifting. The Allowance for Corporate Equity (ACE) form of corporate income tax retains interest deducibility but also provides a deduction for a notional return on equity. It too is a tax on rents, and it too could be border-adjusted. ${ }^{79}$ With appropriate choice of the notional rate, this destination-based allowance for corporate equity would be equivalent in present value to a destination-based cash flow tax..$^{80} \mathrm{~A}$ destination-based allowance for corporate equity would raise fewer transitional issues: it avoids the need for arrangements relating to the initial capital stock (as

\footnotetext{
76 That is, the equivalence is with a 'subtraction-based' VAT, with which there is little practical experience.

${ }^{77}$ Approaches developed in the VAT context-simplified registration requirements and 'one-stop-shop' regimes for firms selling into multiple jurisdictions-could also be used for the DBCFT.

${ }^{78}$ See for instance Schön (2016) and Grinberg (2017).

79 See Hebous and Klemm (2018).

${ }^{80}$ Assuming no allowance for pre-introduction capital under the ACE.
} 
depreciation is maintained) and debt stock (as interest deductibility remains). ${ }^{81}$ To the extent that the notional rate is inappropriate, however, a destination-based allowance for corporate equity, while reducing profit-shifting incentives and tax competition, would not wholly eliminate them: inter-company loans at inflated interest rates remain possible, for example (unless deductibility of interest on related party loans were denied). ${ }^{82}$ While a destination-based allowance for corporate equity may thus be less effective than a destination-based cash flow tax, it nonetheless has many of the same advantages - and could be a stepping stone towards it. ${ }^{83}$

Summary evaluation. Universally adopted, the DBCFT is robust against profit shifting and tax competition; adopted unilaterally, it can aggravate both. Implementation can draw on experience with the VAT, but there are significant legal questions such as those relating to consistency with WTO rules and double taxation agreements. Implications for developing countries remain unclear, but, with source taxation retained for natural resources, these are not necessarily adverse.

\section{Formula Apportionment}

\section{Under formula apportionment (FA), accounts of all a company's affiliates are consolidated to generate a unitary tax base that is apportioned across jurisdictions on a}

formulaic basis. Jurisdictions then apply their own tax rate to the apportioned base. Subnational business taxes commonly work by FA, notably in Canada, Germany, Japan, and the U.S. In Canada, for instance, the unitary base is apportioned across provinces-by commonly agreed rules-payroll and sales, with special weights or formulae applying to certain sectors (such as insurance, banking, and transportation). The provinces retain autonomy to apply their own credits to the apportioned tax base. In the U.S., states can choose different weights for assets, payroll, and sales; and these may vary by sector; Alaska, for instance, uses an origin-based sales factor for extractive industries.

\section{The conceptual and practical difficulties in applying the arm's length principle have} led to proposals to apply FA at the regional or global level. The subnational experiences indicate that, as economic integration proceeds, formula apportionment presents itself as better suited than the arm's length principle for dividing profits of related companies across jurisdictions. In that spirit, the European Commission has proposed a 'Common Consolidated Corporate Tax Base' (CCCTB) for the EU. ${ }^{84} \mathrm{~A}$ two-step approach to implementation is envisaged. First, a uniform common tax base is

\footnotetext{
81 It would also generally be less volatile.

82 More subtly, Hebous and Klemm (2018) show that if the notional interest rate is not set at the correct level, there would be incentives to change the global distribution of debt, and even to manipulate transfer prices.

${ }^{83}$ Closely related to the DBACE would be a Destination-Based Allowance for Corporate Capital (DBACC), which would apply a common notional return on all capital, including debt (Kleinbard, 2005). Its advantage is in eliminating any distinction between debt and equity finance. Like the DBACE, it only eliminates transfer pricing manipulation and tax competition provided the notional interest rate is set at the correct level.

${ }^{84}$ European Commission (2016a). This re-launched, with modifications, a 2011 proposal. For analysis, see Bettendorf and others (2010); Spengel and others (2011), and European Commission (2016b).
} 
established across member states. Second, EU-wide taxable profit is apportioned across member states by three equally-weighted factors: assets, sales by destination and labor (in turn equally weighting payroll and employees). Worldwide formula apportionment has also been proposed by, for example, the Independent Commission for the Reform of International Corporate Taxation (2018) and Picciotto (2016). Support for such proposals often reflects a view that developing countries stand to benefit from formula apportionment, ${ }_{1}^{85}$ given the importance to them of production activities. Whether this is indeed so, is discussed below, but evidence is sparse.

\section{Formula apportionment would greatly reduce the scope for profit shifting, but} introduces other difficulties and is not immune from-might even worsen-tax competition over real location decisions. By taxing multi-national enterprises on a consolidated basis, formula apportionment eliminates scope for profit shifting through transfer pricing and other devices, cutting a swathe through the problems of the arm's length principle. It would induce potential distortions of corporate structures: combining two independent firms would generally change their combined tax liability; ${ }^{86}$ the arm's length principle in principle avoids this, but in practice the current system is far from neutral in this respect. Formula apportionment does not, however, eliminate risks of tax competition if the factors used for apportionment are mobile. Indeed, if production factors are used as weights, tax competition may become more intense, because the revenue gain from attracting such factors comes not from an increase in local activity, but from being allocated a larger share of the multi-national enterprise's overall profit. ${ }^{87}$

\section{The weighting factors used for apportionment determine the distributional and} efficiency effects of formula apportionment. By allocating the consolidated tax base using proxies for substantial economic activities, formula apportionment can align the tax base closely with some obvious fundamentals - where production factors are located, for example, or consumers are based. Ideally, these factors should be easy to verify (to avoid manipulation by companies) and relatively unresponsive to tax differentials (to minimize allocative distortions and tax competition). Commonly used apportionment factors are:

- Production factors. Payroll, employment and assets are commonly used. Payroll would be difficult to misrepresent, and much labor is relatively immobile. For tangible assets, valuation can be non-trivial but there are commonly used methods; they (and some skilled labor) are though relatively mobile, so that differences in tax rates across jurisdictions will distort their allocation. Intangible assets are usually excluded because they are hard to value and relatively easy to relocate; to the extent, however, that intangible assets derive from employment (R\&D workers) or tangible investments (such as laboratories), they are captured by those other factors. If

\footnotetext{
85 See, for example: https://www.taxjustice.net/topics/corporate-tax/transfer-pricing/.

${ }^{86}$ Gordon and Wilson (1986).

${ }^{87}$ Nielsen, Raimondos-Møller, and Schjelderup (2010). These issues are discussed further in McLure and Weiner (2000), Avi-Yonah and Clausing (2008), Altshuler and Grubert (2009), and Clausing (2016).
} 
desired, proxies could also be used in the formula for the value generated by the users of digital services and platforms, although how to best measure this remains unsettled. ${ }^{88}$

- Third party sales. These can be measured on either an origin basis (location of the seller) or on a destination basis. Apportioning by the latter has several of the advantages of destinationbased taxation discussed above, but risks arise in the formula apportionment context through the channeling of sales through low-margin unrelated firms based in low-tax countries. ${ }^{89}$

80. Changes in the tax base from adopting formula apportionment can be significantwith modest but mostly positive effects for emerging market economies. Global revenue might increase under formula apportionment to the extent that the tax base is reallocated from low-tax countries (to which profits are currently shifted) toward high-tax countries. But it might also decrease, since losses can be immediately offset against the profits of affiliates. The net effect on global tax revenue is likely to be slightly positive, and the distributional effects can be large. ${ }^{90}$ Figure 6 illustrates this, showing results from simulations (described in Appendix IX) based on two datasets: aggregate data on U.S. multi-national enterprises, and firm-level data on global multi-national enterprises. The results are no more than illustrative: they differ significantly between the datasets, and coverage of developing countries is very sparse. But there are some consistent messages:

- Advanced economies are more likely to gain revenue if apportionment is by value added, payroll or sales, and somewhat less likely to benefit if it is by employment;

- 'Investment hubs' are likely to experience significant reductions in tax base;

- Emerging economies tend to benefit from formula apportionment, although this is clearest for apportionment by employment or sales, and less so if by value added or payroll;

- Developing economies may benefit if apportionment is largely by employment.

81. It would be challenging to secure international agreement on a common tax base. ${ }^{91} \mathrm{~A}$ unitary group needs to be defined and its consolidated tax base calculated on a common set of rules (following, for example, the International Financial Reporting Standards). Some flexibility could be achieved by allowing countries to modify their apportioned share of the unitary base (by for instance offering additional $R \& D$ deductions), but with the downside of creating additional instruments for tax competition.

\footnotetext{
${ }^{88}$ In its draft Directive the EC notes that the CCCTB rules would need amendment to capture digital activities.

${ }^{89}$ This issue does not arise under the DBCFT/ACE/ACC, since cumulative liability depends only on the location of the final purchaser, assumed immobile.

90 See for instance Devereux and Loretz (2008), Hines (2009), Cobham and Loretz (2014), and IMF (2014).

91 The appropriate choice of base is not explored here, beyond noting that the tax could be shaped as one on rents by structuring it as an ACE (as in the early proposal of European Commission, 2016c) or a cash flow tax.
} 
Figure 7. Tax Base Effect of Formula Apportionment

(in median impact per group, percent change)
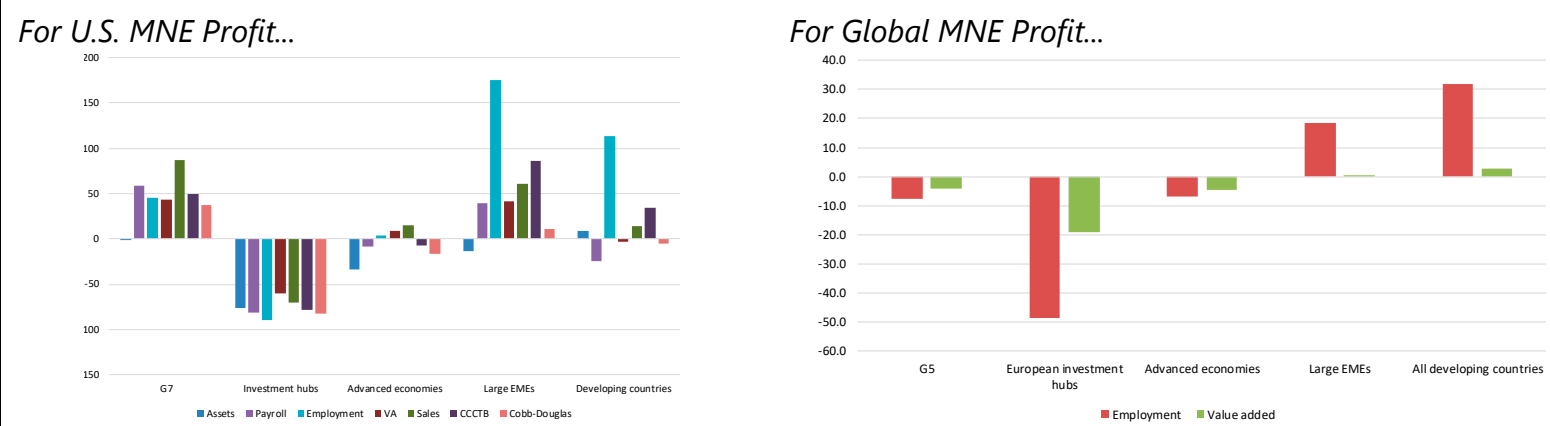

Source: IMF staff analysis based on data from the BEA and ORBIS. See Appendix X.

Note: G-5 = France, Germany, Italy, Japan, U.K.; G-7 = G5 + Canada, U.S.; European investment hubs = Ireland, Luxembourg, Netherlands, Switzerland; Investment hubs = European investment hubs + Bermuda, Hong Kong SAR, Singapore, U.K., Caribbean; Large EMEs = Argentina, Brazil, China, India, Indonesia, Mexico, Russia, South Africa, Turkey, UAE. For other advanced economies and emerging market economies, see Appendix X.

\section{And it would likely be even more challenging to secure agreement on the}

apportionment formula. Allowing countries to choose their own, as practiced at state level in the U.S., can lead to either more or less than 100 percent of total profits being allocated somewhere, and divergent weights evidently complicate implementation. It can also induce tax competition through the choice of weights: U.S. states, for instance, have moved away from using payroll and assets, towards a larger weight for destination-based sales, presumably to attract employment and assets. As experience with the European Commission's common consolidated corporate tax base proposal makes clear-and the results above illustrate-countries have such substantially different interests that agreeing on a common apportionment scheme would be extremely difficult. ${ }^{92}$

\section{Agreeing on regional formula apportionment among relatively homogenous countries} might be easier, but maintains current vulnerabilities in dealing with third countries. Under the common consolidated corporate tax base proposal, for instance, companies would consolidate only their profits earned within the EU, using the arm's length principle to allocate relative to non-EU affiliates. This can significantly limit the benefits of formula apportionment and raises questions regarding the application of member states double taxation agreements with non-EU countries. ${ }^{93}$

\section{Formula apportionment might be simpler to administer and comply with than the current system, although this depends on its design and generality of application. So far as} transfer pricing issues are eliminated, formula apportionment would bring simplification and a likely reduction in compliance and administrative costs. ${ }^{94}$ But complexities may arise too: for instance, with the definition of a unitary group. Agreement on apportionment factors and accounting rules will be

\footnotetext{
92 The Canadian FA arrangements, which-unlike those in the U.S.-emerged with central coordination, have proved robust against pressures toward sales-only apportionment (Weiner, 2005). They have also been supported by an equalization system that moderates their incentives to engage in tax competition (because gains obtained from attracting a larger portion of the tax base are partly offset by transfers to other provinces: Smart (2007)).

93 Schön (2007).

94 Transfer prices will, however, still need to be determined for trade purposes.
} 
key to simplicity, and the need for cross-border cooperation enhanced: countries will seek assurance, for instance, that apportionment factors relating to activities outside their jurisdiction are properly calculated. Country-by-country reporting (a BEPS minimum standard) might help, but is currently not designed for this purpose and only applies to the largest MNEs.

\section{There may also be legal obstacles (beyond those associated with destination taxation)} to introducing formula apportionment in relation to existing treaties, which are built on separate accounting concepts. One suggestion is that treaty partners agree to interpret their treaties to accept the apportionment approach as being a feasible and administrable approximation to the arm's length principle. ${ }^{95}$

Summary Evaluation: Formula apportionment addresses profit shifting, but, depending on the method of apportionment, scope for tax competition remains. Legal issues arise from the need to establish new norms, but administrative challenges are modest. The revenue gain for developing countries may be modest (at best) unless apportionment attaches heavy weight to employees.

\section{E. Sharing Residual Profit}

\section{Much discussion and several recent proposals center around a distinction between} 'residual' and 'routine' profit. The terms are often used loosely, but broadly:

- By 'routine profit' (a term of transfer pricing art) is meant an acceptable return to some activity or function-broadly equivalent to a normal return (that is, the minimum required) on the underlying activity (assembling a product's subcomponents, or providing warehousing). How this is currently calculated in practice is context-specific, the general aim being to identify the return earned by an entity undertaking that activity on an outsourced basis. For activities intense in capital assets, it might be calculated by applying some notional return to those assets based on comparable third-party experiences; in other cases, a markup, based on financial statements of comparable independent companies, is applied to purchases from third parties and labor costs. The application of ALP methods in calculating routine profit is widely, though not universally, regarded as reasonably effective and robust against manipulation. Some of the schemes that have been proposed, however, simply apply common markups to all cases.

- By 'residual' profit is meant the excess of aggregate profit over routine profit. To the extent that routine profit can be identified with a normal return on investment, residual profit is identified with rent. It will tend to include that part of profit which-due to intangibles or risk-bearing, for instance-is hardest to allocate across jurisdictions by standard transfer pricing methods.

\footnotetext{
${ }_{95}^{9}$ Avi-Yonah, Clausing, and Durst (2009).
} 
87. OECD guidance ${ }^{96}$ allows allocating residual profit in relation to specific transactions and case-by-case. It envisages use of the 'profit split' method ${ }^{97}$ when both sides of a transaction make unique contributions that are hard to value-though only in relation to specific sets of transactions and with the method of calculation differing according to facts and circumstance.

88. In contrast, recent proposals envisage apportioning residual profit on a unitary basisso are 'hybrids' combining elements of formula apportionment and the conventional arm's length principle. Their common structure is that routine profits are allocated for taxation where the associated costs (purchases from third parties) are incurred while residual profits are allocated (to some degree, if not wholly) on some formulaic basis. Countries may then choose to tax these two elements—routine profit earned in their jurisdiction, and the residual income they are allocated-at different rates. We refer to this family of schemes as ones of Residual Profit Allocation (RPA).

\section{Residual profit allocation proposals differ widely, notably but not only in the proposed allocation of residual profit. Examples include:}

- HM Treasury (2018b) envisages allocating residual profit of certain highly digitalized business models in part by some indicator (perhaps based on revenue or the number of active users) of the value created by user participation.

- The U.S. has proposed allocating residual profit attributable to 'market intangibles' ${ }^{\prime 88}$ (such as trademarks and brand recognition) to the market country with which they are associated. ${ }^{99}$

\section{Others apportion residual profit in their entirety:}

- An early proposal ${ }^{100}$ was to calculate routine profit by applying an agreed markup on third party costs and apportion residual profit by destination-based sales.

- A recent alternative apportions residual profit by destination-based sales less third-party costs (inclusive of the routine return) associated with them. ${ }^{101}$ One appealing feature of this schememaking it more familiar to practitioners-is that the final allocation can be reached not only by apportionment but by intuitive hypothetical transfer pricing adjustments.

\footnotetext{
96 OECD (2018).

${ }^{97}$ Formally, the 'transactional profit split method'.

${ }^{98}$ As opposed in particular to 'product' or 'trade' intangibles reflecting for example R\&D and product design.

${ }^{99}$ See, for example, reported comments made by U.S. Treasury officials at the 31st Annual Institute on Current Issues in International Taxation, held December 13-14, 2018 in Washington, D.C. Grinberg (2018) provides a detailed assessment.

100 Avi-Yonah, Clausing, and Durst (2009).

101 This is the 'Residual Profit Allocation by Income' (RPA-I) of Auerbach and others (2018). A merit of this relative to fully sales-based allocation is that it allocates less residual profit to jurisdictions that are costlier to serve.
} 
91. There have been several other residual profit allocation proposals in recent years, differing in important ways. ${ }^{102}$ One might even interpret the US global intangible low taxed income and foreign derived intangible income provisions of the Tax Cuts and Jobs Act as a form of residual profit allocation applied to income earned outside the U.S. (including by exporting), deeming a routine return of 10 percent on tangible assets (wherever located) and allocating half of the implied residual to the U.S.

\section{The implementation issues raised by these proposals differ, but commonly include a} fundamental change of principle in extending taxing right to destination or 'user' countries. The U.K. proposal, for instance, raises the practical issue of how to quantify user value, and leaves open the allocation of other sources of residual profit. Schemes that allocate partly by destination face the possibility, as under standard formula apportionment, of avoidance by multi-national enterprises selling final products to third party distributors in low tax jurisdictions. And schemes that operate on a product or product line basis can add their own complexities and opportunities for manipulation by strategic choice of product groupings. A common feature of many such schemes, however, is that they envisage taxing rights being established even in the absence of a traditional permanent establishment. This is a fundamental shift of principle, likely to require, for instance, amendment of existing tax treaties-either to create a 'virtual permanent establishment' as discussed above or to establish a generalized right to tax in the destination country.

\section{Residual profit allocation schemes substantially eliminate opportunities for profit} shifting, but do not eliminate distortions or, depending on design, fully address tax competition concerns. Scope for profit shifting is limited to routine profits; but the presumption is that the arm's length principle can identify these reasonably accurately. The taxation of normal returns retains a distortion inherent in most current corporate income taxes; and the element of origin taxation in doing so creates incentive for tax competition to attract mobile routine activities. The force of this consideration may be modest, however, in that competition is only over a normal return, not rents. There may, nonetheless, be a case for adopting minimum tax rates on routine profits, while maintaining national discretion over rates applied to residual profits, especially if the latter were allocated by some relatively immobile quantity, such as destination-based sales. Incentives to compete to attract residual profit depend on the apportionment formula, with an element of formula apportionment in residual profit allocation schemes meaning that the same forces potentially encouraging tax competition between governments (and game-playing by firms) identified above remain. They are lessened to the extent of apportionment by destination-based sales or user participation.

94. Little thought has been given to the implications of residual profit allocation proposals for developing countries. The interest in allocating residual income has come largely from the desire of advanced countries whose companies create valuable intangibles and whose users are seen as generating considerable value to ensure these contributions are reflected in their tax base.

\footnotetext{
102 In, for instance, the calculation of routine profits, crediting arrangements for taxes on routine and residual profit,
} the precision of the proposed allocation of residual profit and in whether applied company-wide or by product. 
Much of course, depends on how residual profit is apportioned. For resource-rich countries, and as with formula apportionment, it seems reasonable to suppose that as a matter of both principle and practical politics, associated residual income will be allocated largely where the underlying resources are located. For non-resource rich developing countries, allocating residual profit by final sales is likely to be less advantageous than allocation by some indicator of activity-but, for those with trade deficits, not necessarily wholly adverse. It may be, moreover, that tax avoidance by multinational enterprises means that residual profits—and even routine profits—are little taxed in these countries, but largely shifted to low tax jurisdictions. To the extent that residual profit allocation strengthens their ability to tax routine profit, it may on this account ultimately be to their benefit. The calculus of national gain or loss from alternative schemes, however, is ultimately an empirical and country-specific matter.

\section{Empirical evidence on the level and distribution of residual and routine profits-across both countries and forms-is scant, hampering the evaluation of residual profit allocation proposals. Highly tentative empirical analysis reported in Appendix X, suggests, however, that:}

- Residual profit is highly concentrated among a small number of firms: about one-third of all residual profits accrues to the largest one percent.

- ...and is also concentrated among firms headquartered in a few economies (notably the U.S., U.K., Japan, China, and Hong Kong SAR).

- Many multi-national enterprises appear to have negative residual profits (this may be an artefact of assumptions behind the calculations, but highlights the practical issue of how to apportion residual losses).

- Many countries may currently collect less revenue than they would by fully taxing routine returns (Figure 8).

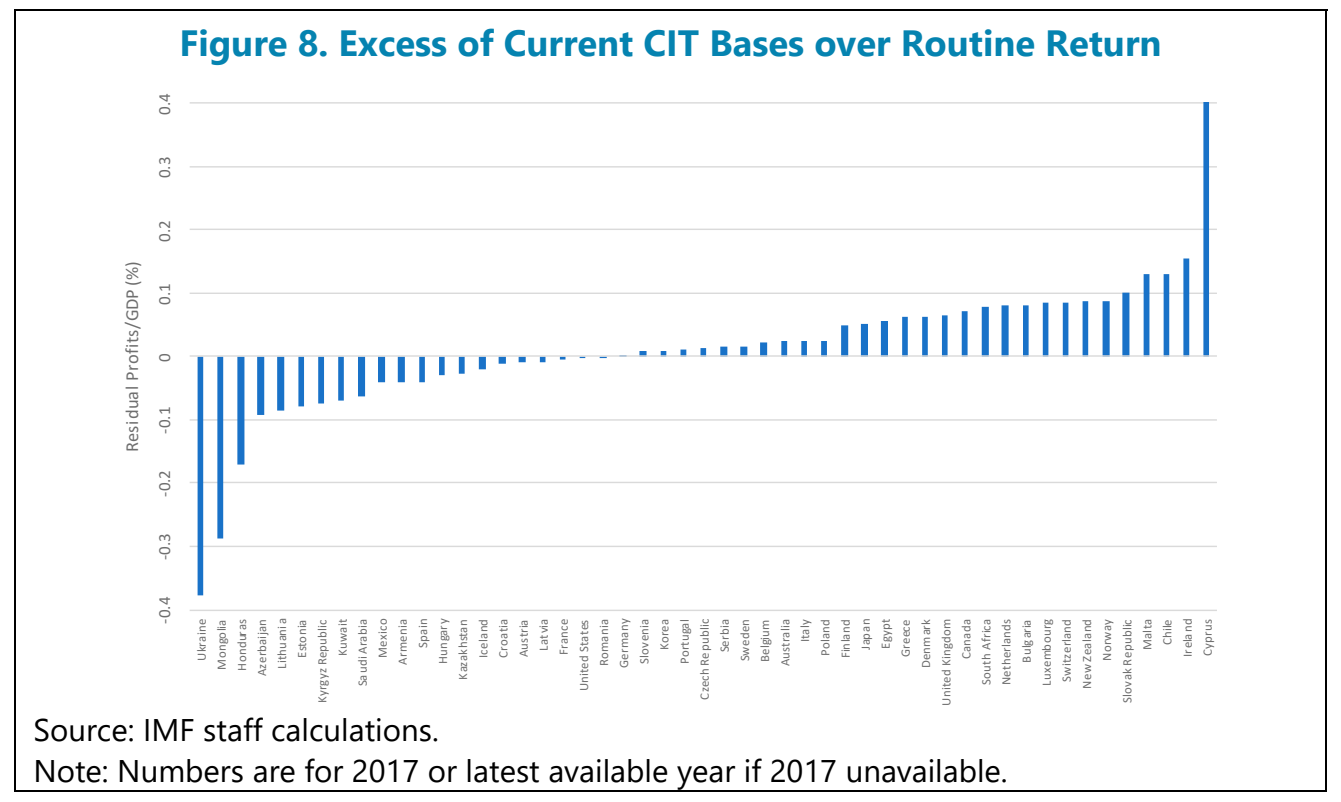


96. Reducing profit shifting under residual profit allocation would benefit many countries, but the effect on the distribution of tax revenue may be dominated by how residual profit is allocated. Illustrative modeling in Appendix $\mathrm{X}$, taking the example of wholly sales-based residual profit allocation, suggests that effects through reduced profit shifting may be modest relative to those from reallocating residual profit. Empirical understanding of patterns of routine and residual profit, and the impact of alternative residual profit allocation schemes remains limited.

\section{Cross-country coordination would be needed for generalized adoption of residual profit allocation schemes-though whether more or less than for outright formula}

apportionment is unclear. Whereas the adoption by one large country of a destination-based cash flow tax, for instance, would generate strong incentives for others to follow suit, it is not clear there would be similarly spontaneous coordination on any residual profit allocation scheme. A high tax jurisdiction that barely manages to tax even routine profit might have an incentive to join a destination-based residual profit allocation scheme if it has a significant domestic market, since it would then be allocated some part of the residual profit currently shifted elsewhere. But a low tax jurisdiction with no significant domestic market may prefer not to join if participation required it to raise the rate it applied to routine profits. Countries would in any case differ in their preferred apportionment, creating the same difficulties as noted above for formula apportionment.

98. The implementation and legal issues raised by residual profit allocation follow from its nature as a hybrid. Essentially the same issues as for formula apportionment arise in the sharing of residual profit. And the familiar tension arises between simplicity and accuracy: calculating routine profits by applying general markups, for instance, is easier, but cruder, than doing so through caseby-case application of the arm's length principle.

\section{The current focus on residual income and its allocation provides a constructive}

framework for progress. Views will differ on the appropriate apportionment and much detail and empirical understanding remains to be developed. Nonetheless, this focus signals a recognition that the arm's length principle has proved capable of dealing with relatively straightforward operations, but not of addressing the full complexities of transactions within modern MNEs. While preserving a significant element of source taxation, the RPA approach thus provides a framework within which substantial progress might be made while retaining familiar elements of current arrangements.

Summary Evaluation: Residual profit schemes can effectively address the main forms of profit shifting, though scope for tax competition remains, including in relation to routine profits.

Administration requires the additional step of dividing profit into two components, but the scheme retains significant features of current norms and practice making legal implementation less difficult. Secure taxation of a routine return could be attractive for many developing countries. 


\section{F. Summary}

100. The considerations set out above do not lead to endorsement of any specific proposal. They can only guide the further analysis and debate needed of precisely defined options. In that spirit, Table 2 provides an impressionistic summary evaluation of the schemes discussed above-assuming general adoption. ${ }^{103}$

\section{Table 2 is to be interpreted with great caution:}

- There is wide variation not only between but within these classes of scheme: introducing an element of destination-based apportionment into formula apportionment, for instance raises a distinct set of legal issues; and minimum outbound taxes that condition on taxes paid abroad are less simple but also less distorting than those which do not.

- Schemes may be combined, and sequenced, in differing ways: formula apportionment could be combined, for example, with minimum taxes; and residual profit allocation schemes could lead to full formula apportionment.

- The implications of unilateral adoption could be quite different to those of universal adoption.

102. No scheme is without difficulty, and any assessment will ultimately depend on the weights attached to the various criteria used. But some general les sons emerge:

- Other than the minimum tax schemes, all variants extend the notion of taxable presence beyond current norms. ${ }^{104}$

- Expanding the notion of permanent establishment within the current architecture would have a modest impact on profit shifting and tax competition; and how profits would be attributed remains unclear.

- The destination-based cash flow tax scores very strongly on protection against both profit shifting and tax competition, and well on practical implementation; but its impact on low income countries remains uncertain, and raises distinct WTO issues. ${ }^{105}$

- Minimum tax schemes achieve a good deal, including in protecting the tax base of low income countries in a simple manner-although at the risk of creating distortions, including in violating capital export neutrality. Since they face only modest legal obstacles, when well designed, they can be implemented relatively quickly, perhaps as a transition to more fundamental change.

- Residual profit allocation and formula apportionment achieve progress by renouncing, to differing degrees, the arm's length principle. The former has practical appeal, given the current state of international tax arrangements and debate, as a hybrid of the two. Residual profit

\footnotetext{
103 It is also assumed that natural resources and other sources of LSRs remain subject to source-based taxation.

104 The minimum approach would too if extended to include a user/destination-based element.

105 With global adoption, the significance of this would be moot.
} 
allocation is more challenging to administer, since it involves an additional step in identifying a routine return, but marks out a clear minimum tax base for low income countries. Global adoption, as envisioned here, would require substantial agreement on the apportionment formula, which may be easier to secure with country rights firmly protected under residual profit allocation.

\section{All alternatives can accommodate approaches to digitalization of the kind envisaged} in the long-run solutions described above-subject to broadly similar issues arising in defining presence and establishing the value of user participation. Minimum tax schemes could be overlain on such arrangements, and user participation used as an apportionment factor under formula apportionment/residual profit allocation. Under the destination-based cash flow tax, earnings on barter-type arrangements would net out to zero if implicit prices paid on the two sides are regarded as equal, but questions arise if they are not. ${ }^{106}$

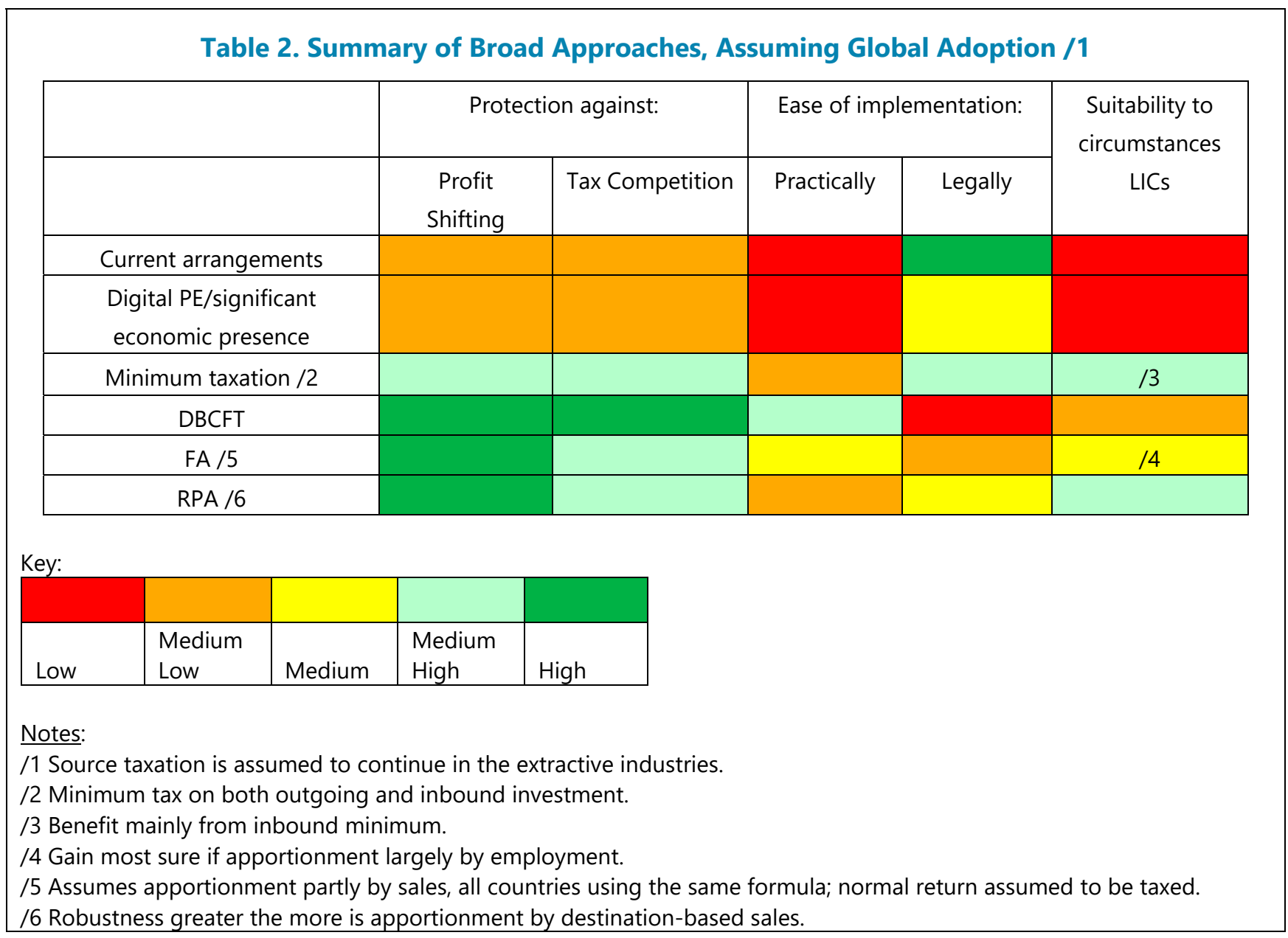

106 Devereux and Vella (2017). 


\section{GOVERNANCE OF THE INTERNATIONAL TAX SYSTEM AND THE ROLE OF THE INTERNATIONAL FINANCIAL INSTITUTIONS}

104. Smooth functioning of the international tax system requires much consensus-and the alternative architectures above likely require, to differing degrees, more than yet seen. Unilateral and uncoordinated measures of the kind that have begun to emerge threaten to descend into disorder. A coordinated approach is needed to minimize adverse spillover effects in addressing the challenges set out above. To this end, all the alternative futures sketched above require more cooperation than has yet been achieved, though to varying degrees. Movement towards minimum tax schemes, for example, requires far less coordination than would agreement on the weighting to be used in some mechanical split of profits. While the urgent priority is to sustain the increased cooperation in international taxation recently achieved, securing a coherent and productive future for the corporate tax requires deepening it still further.

105. Countries prize their sovereignty in tax matters but accept constraints on it, in both hard law (through the WTO, regional agreements, bilateral double taxation agreements) and soft law (for example in relation to exchange of information and BEPS). They also enter into multilateral arrangements ${ }^{107}$ that enhance their ability to assert sovereignty in administering their tax laws. What is lacking is a comprehensive framework for agreeing and enforcing common views on core aspects of rates and/or bases of taxation as they operate internationally-matters that need to be addressed head on.

106. There are fundamental obstacles to deep agreement on international tax issues. That there is no "World Tax Organization" (though this has had its advocates) ${ }^{108}$ likely reflects not simply concerns with sovereignty but structural considerations making it harder to reach international agreement in the tax area than, for example in relation to trade. One is the absence of principles for international taxation as powerful as the case for trade liberalization. Another is that while in trade policy it is the actions of large countries that shape the outcome, in the context of tax competition small countries can clearly have considerable influence. Effective agreement must, somehow, embrace not just a few large players but a large number of potentially small ones. With winners from tax competition as well as losers, side payments (or coercion) may ${ }^{109}$ be needed to bring about coordinated action that benefits all. Coordination among a subset of countries can be helpful, particularly aligning countries around good practices. But it can be less effective in dealing with tax

\footnotetext{
107 Including the Multilateral Convention on Mutual Administrative Assistance in Tax Matters and other agreements to enhance the effectiveness and efficiency of their operations (such as those of the World Customs Organization).

108 Notably Tanzi (1995).

109 Though not always: there are, for instance, cases in which agreement on minimum tax rates can benefit even those countries thereby obliged to increase their rate: see Keen and Konrad (2013).
} 
competition, since constraining competition within the group may make its members more vulnerable to tax competition from those outside ${ }^{110}$ — creating an incentive not to participate.

\section{Developments in tax cooperation are driven by the most advanced economies-} causing some unease. A caricatured view of international tax history in recent decades is that "the United States takes the lead, the OECD and its members reach a compromise, and the rest of the world follows the OECD." 111 It was doubtless natural that the advanced economies, intensely engaged in cross-border investment for decades and with unmatched expertise, play a lead in the evolution of international tax norms. But increased awareness of how important international tax issues are to the revenue prospects of developing countries has led many, including in civil society, to the view that the system over-protects residence countries' rights relative to those of source countries. All this creates some unease with the shaping of the system by advanced economies, whose interests sometimes align with those of LICs (in relation to low tax jurisdictions, notably)—but sometimes do not. It can be difficult for non-EU members to accept, for instance, an EU listing process that imposes EU and OECD standards on non-EU members that were not involved in setting them. ${ }^{112}$ Substantively too, standards developed for more advanced economies do not necessarily translate easily to the circumstances of developing countries. Some may have difficulty, for example, meeting the standards required to benefit from country by country reporting. More generally, it is important to recognize that, given their deeper challenges in mobilizing revenue, international tax issues are not necessarily such a priority for low income countries as for advanced/emerging economies, and to ensure that pressures to comply with standards driven by those countries do not distract low income countries' scarce talent and resources away from more pressing revenue needs and wider reform efforts.

108. Addressing current problems requires more effective and inclusive cooperation than in the past-developing which is very challenging. Locating the lead institutional responsibility in international taxation has proved highly contentious: a major disagreement at the 2015 Addis Ababa Conference on Financing for Development, for instance, was on whether to upgrade the UN ${ }^{113}$ Committee of Experts on International Cooperation in Tax Matters to an intergovernmental body (with members representing their respective governments), a proposal supported by many developing countries and by some tax activists and academics. ${ }^{114}$

\footnotetext{
110 Konrad and Schjelderup (1999). Building on this, Konrad and Thum (2018) argue that the regional tax coordination can plausibly be a stumbling block rather than a stepping stone to global agreement.

111 Li (2002), pp. 867.

112 This is not to say that some degree of pressure to induce cooperation is inappropriate: indeed, it can help to overcome free-rider problems in a way from which even those pressured may benefit. But the perception of legitimacy and inclusiveness can suffer. See for instance Oxfam (2017).

113 The UN is traditionally seen as particularly protective of the rights of developing countries: see for instance Lennard (2009).

114 See, for instance, Statement of Egypt on behalf of Group of 77 and China to the ECOSOC Special meeting on International Cooperation in Tax Matters (New York, May 18, 2018) http://www.g77.org/statement/getstatement.php?id=180518b; https://www.theguardian.com/global-
} 
109. The creation of the OECD's Inclusive Framework (IF) is a positive development. It embodies effective features in operating through soft law standards, supported by mechanisms to ensure effective global implementation. The mechanisms also avoid the legal complexity associated with developing a body based on "hard" obligations (for instance, based on one-country-one-vote or quota-based systems). The "soft" law approach"115 also lends itself to a consensus-based mechanism. ${ }^{116}$ These features mean the Inclusive Framework holds potential of enhanced cooperation beyond the implementation of BEPS for which it was created. Realizing the full potential of the IF would, however, require taking on issues not covered by BEPS but of particular interest to developing countries, such as the issue of service fees raised above. More generally, it would mean engaging with the possibility of more fundamental reforms, including those outlined above.

110. Not all, however, see the Inclusive Framework as adequately accommodative of the views and circumstances of non-G-20/OECD countries. While the Inclusive Framework places all members on an equal footing for the BEPS implementation, they were not on an equal footing when those standards were set. The weight attached to the distinct circumstance and interests of lower income countries-on both agenda-setting and in outcomes reached-is likely to be limited, moreover, by both the lesser capacity of many to engage on the highly technical (and fast-moving) issues at stake and the dispersion of bargaining power among them. The former calls for external support; the latter perhaps for the formation of 'like-minded groups' among them. ${ }^{117}$

111. The IMF has important contributions to make. International tax issues arise frequently in the country-specific advice and the training that the Fiscal Affairs and Legal Departments offer to over 100 members each year. Advice is country-specific, though there are common themes (including not least the importance for low income countries of securing the tax base on inbound investment). Increasing attention is also being paid to these issues in bilateral surveillance, often focused on spillovers. Since 2016, such analyses in the context of Article IV consultation have been undertaken for Belgium, Canada, Denmark, Egypt, France, Hong Kong SAR, Indonesia, Iran, Ireland, Jamaica, Kenya, Malaysia, Mali, Nicaragua, Peru, Switzerland, Tanzania, the Philippines, the U.S., and Uganda - with more in process. Topics include: the overall treatments of capital income, the impact of the recent US tax reform, the effects of double taxation agreements for low income countries, and the use of withholding on cross border services. Those analyses, along with others undertaken in capacity development and new analytic work, are providing regional synthesis papers on international corporate taxation issues for advanced European countries and for sub-Saharan African

\footnotetext{
development/2015/jun/25/ten-reasons-why-european-governments-should-back-global-tax-body; and Avi-Yonah and $\mathrm{Xu}$ (2017).

115 Underpinned by a functioning dispute settlement mechanism, with supporting mechanisms to encourage countries to abandon practices inconsistent with the agreed soft law principles.

116 A soft law approach can, however, be "vulnerable to political whims" (Cockfield, 2018, pp. 225).

117 As proposed by Rosenbloom, Noked, and Helal (2014).
} 
countries, with similar work having been done in Asia. ${ }^{118}$ The Fund also produces guidance materials, ${ }^{119}$ and its conceptual and empirical contributions are much noted.

\section{Research and data gaps continue to hamper full understanding of the distinct} circumstances of developing countries, and hence the appropriate tailoring of international tax arrangements. There has been recent progress, but coverage of developing countries in standard data sources remains low-as evidenced by the small number included in the exercises reported above. The information that will be obtained from country-by-country reporting can clearly be helpful in this regard. More generally, increased access to and use of micro-level tax administration data, including in the wider academic community, is critical for further advance. Its potential value has been shown in relation to the VAT, for instance, by the IMF's RA-GAP program. ${ }^{120}$ Similar work on international tax matters for low income countries remains in its infancy.

\section{A fuller role could be played by the Platform for Collaboration on Tax (PCT). ${ }^{121}$ The} current institutional environment for international tax cooperation has critical roles dispersed through several international and regional organizations, ${ }^{122}$ with important functions performed by all Platform partners. None has all the attributes required to enable effective and inclusive tax cooperation-but each has some. The OECD and UN have expertise in multilateral standard setting. The IMF and World Bank are leading providers of capacity building not only in international taxation but, and as part of their engagement with their members, revenue and spending systems more widely. Together with the UN, they also have an inherent inclusiveness from their broad membership and mandates. Reflecting these comparative advantages, the PCT was established as a central vehicle for its partners' enhanced cooperation, enabling them to develop a common approach, including regarding spillover analysis and advice, deliver joint outputs, and better respond to requests for a global dialogue on tax matters. The PCT is not intended to set standards or monitor implementation, but, for example, to "identify and analyze emerging international tax issues, especially those of interest to developing countries-including with a view to possibly bringing them to the attention of the Inclusive Framework." 123 A more purposive engagement of the PCT with the work of the IF might help to build the inclusive and informed engagements-and shared understanding - needed for substantial and consensual progress to be made in strengthening the international tax system. Indeed, some respondents during the consultations for this paper expressed a desire for the PCT to play a more prominent role in the international tax dialogue.

\footnotetext{
118 Underlying a regional ASEAN conference in 2017.

119 One example being Waerzeggers and Hillier (2016).

120 Hutton (2017).

${ }^{121}$ Formed in 2016, the PCT brings together the IMF, OECD, World Bank, and the UN: http://www.worldbank.org/en/programs/platform-for-tax-collaboration

122 Including in particular the regional tax administration organizations, several now gathered into the Network of Tax Organisations, facilitated by the International Tax Compact.

123 PCT (2016), Box 1, pp. 4.
} 
114. A more comprehensive multilateral approach is needed. There are good grounds to be skeptical that a new and more comprehensive governance framework for international corporate taxation will emerge soon. Nonetheless an approach more universal in its full inclusion of countries and its coverage of fundamental policy issues is needed as it becomes increasingly apparent that the current approach cannot deal adequately with mutually harmful spillovers and distortions from uncoordinated policies. There is scope and need to build on the progress that has been made. The Inclusive Framework and the PCT, for example, can do more to ensure that the concerns of lower income countries are placed firmly on the international tax reform agenda.

\section{ISSUES FOR DISCUSSION}

\section{Directors may wish to discuss the following issues:}

- Do Directors agree that the international corporate income tax system requires substantial reform, as described in the section "Taking Stock," paragraphs 6-19?

- Do Directors believe that 'digitalization' requires specific tax solutions, or rather that it is impossible/undesirable to ring-fence "digital" activities or firms, as discussed in the section "The Digitalization Debate," paragraphs 20-29?

- Do Directors agree that IMF advice should reflect the potentially differing impacts on lowincome countries of possible approaches to reforming the tax architecture, as discussed inter alia in paragraphs $15-16,36,53-58,67-69,80-81,94-95$, and $102 ?$

- Do Directors have views on the alternative architectures described in the paper, and do Directors agree with staff's analysis of those alternatives, as discussed in the section "Alternative Architectures" and summarized in Table 2?

- Do Directors agree that more country specific taxpayer-level information is needed to analyze the impacts of international tax arrangements, especially for developing countries, as suggested in paragraph 111? If so, do Directors see a role for the Fund in encouraging the collection and analysis of such data?

- Do Directors feel that current governance arrangements in international taxation are adequate and equitable, as discussed in paragraphs 103-113? What role do Directors see for the PCT in the area of international tax? 


\section{Appendix I. Consultation}

1. There has been considerable interest in this project. Written comments were sought online (responding to questions covering the topics addressed in this paper), and 11 detailed submissions totaling more than 100 single spaced pages-some representing views of multiple CSOs - were received. ${ }^{1}$ Direct consultations also took place, including: in a non-confidential East Africa regional outreach event held in November 2018 in Tanzania; ${ }^{2}$ a series of meetings with stakeholders in several European countries in September 2018; and meetings in China and Japan in October 2018. Informal discussions were also held with several academic economists, policy advisors and legal experts. A brief summary of main points and views follows.

\section{Many respondents and participants felt that the BEPS project, while useful in several} ways $^{3}$ suffered from two serious flaws: (1) Continued reliance on the ALP, which was very widely seen as no longer suited to modern economic structures; as relying on the "economic fiction" of separate entities; as increasingly complex; and as inappropriate, disadvantageous to, and hard to implement by LICs; and (2) Essentially all respondents from developing countries and CSOs noted the deliberate avoidance of considering the balance between source and residence taxation, seen as failing to respond to the needs and interests of developing countries. Several CSOs noted the need for an inclusive process that would go beyond the G-20 and not exclude options for deeper reforms.

\section{Many respondents and interlocutors noted that tax competition is likely to intensify,} with significant spillovers on developing countries.

\section{Essentially all agreed that increased digitalization of the economy significantly} exacerbates the problems in the current international tax framework. Unilateral measures, such as turnover taxes, were generally viewed by CSOs, LICs-and some others-as unhelpful.

\section{CSOs, and some developing country representatives, proposed that:}

- Unitary taxation would be simpler, more effective and more equitable than the ALP. But appropriate-and substantially agreed-apportionment factors would be required. Some noted, however, that unitary taxation would not eliminate tax competition without consistent apportionment factors and perhaps only combined with....

\footnotetext{
${ }^{1}$ Comments are available online.

2 More than 2 dozen participants included representatives from the following organizations: Uganda Ministry of Finance; Uganda Revenue Authority; Zambia Revenue Authority; Malawi Ministry of Finance; Rwanda Revenue Authority; Tanzania Ministry of Finance; Tanzania Revenue Authority; Civil Society for Poverty Reduction (Zambia); Oxfam in Kenya; Tax Justice Network Africa; National Taxpayers' Association (Kenya); Natural Resource Governance Institute (Tanzania); CSBAG (Tanzania); PwC; EY; KPMG; B\&E Akolaw (Tanzania); FB Attorneys (Tanzania).

${ }^{3}$ Though some noted that the implementation of even some of these welcome BEPS measures, such as the minimum standard of $\mathrm{CbC}$, encounter capacity constraints in many developing countries.
} 
- ...a general minimum tax. A minimum tax alone could constitute an option for a partial fix within existing arrangements, but would not address the system's deeper flaws.

- Some felt that residual profit allocation methods-if suitably and simply designed, and again mentioning minimum taxes-could constitute a significant improvement, and possibly create a path to later adoption of formula apportionment.

- Destination-based taxation was seen as essentially mimicking the value added tax and was opposed by all CSOs and LICs, as well as some academics.

- These groups also generally opposed imposing the CIT only on economic rent.

- An inclusive global governance for setting international tax standards and advancing international collaboration was viewed as needed. Most CSOs favored a regime under the auspices of the UN.

6. Government officials from developing countries also highlighted:

- Tax treaties' risks for source countries, particularly with investment hub countries.

- Challenges faced in taxing cross border service payments.

- The need to attribute the taxing rights of LSRs to source countries.

7. Some government officials from developed countries noted that:

- A minimum tax could be used to strengthen the current international tax framework.

- A residual profit split method has potential merits.

- Digitalization requires recognizing the value created by consumers and users; ultimately a global solution, rather than interim measures, is needed.

8. Some business representatives noted that:

- The G-20/OECD BEPS project has increased complexity.

- A residual-profit method could be better suited than current arrangements to cope with a greater global business integration and group risk diversification.

- Withholding taxes are often relatively high in developing countries-speaking to the value of DTAs-and DTAs frequently do encourage FDI in LICs. 


\section{Appendix II. The International Tax Framework-Core Elements and Concepts}

\section{Core elements of today's international tax architecture-much of which dates back to a 1923 League of Nations report ${ }^{1}$-include:}

- The principle of arm's-length pricing (ALP), by which transactions between entities within an MNE are to be valued for tax purposes at prices to which independent parties engaging in the same transaction in similar circumstances would agree.

- Net Income from business activities of a corporation is allocated first to the "source" country in which it is generated, with a residual right to tax in the country of residence of the company, generally with a credit for taxes paid in the source country to relieve double taxation. ${ }^{2}$ The right to tax "passive income,"-e.g. interest, royalties, dividends-is generally allocated to the country of residence of the recipient company, it having been thought harder to locate the "source" of such income.

- Taxation of business profits by the source country, however, requires that there be "nexus" in the form of a permanent establishment (PE), which requires a substantial degree of physical presence in a country. ${ }^{3}$

- Corporate taxation of foreign income is deferred until repatriation to the resident company, with Controlled Foreign Corporation (CFC) rules often adopted in order to bring into tax in the residence country that income, especially passive income and sometimes low-taxed other income, earned by foreign subsidiaries of the resident company abroad.

- Double Tax Agreements (DTAs), generally bilateral, aim to allocate the tax base across countries consistent with the broad principles. While avoiding overlapping claims to tax income they now also recognize risks of 'double non-taxation.' The treaty network has expanded massively in the last 25 years or so, there now being more than 3000 DTAs, and the network has grown to encompass relations between developing countries (generally 'source only" and capital importing) and advanced economies. ${ }^{4}$

\footnotetext{
${ }^{1}$ Report on Double Taxation submitted to the Financial Committee-Economic and Financial Commission Report by the Experts on Double Taxation—Document E.F.S.73. F.19 (April 5th, 1923)—Vol. 4 Section 1: League of Nations.

2 Increasingly, residence countries are giving up the residual right to tax business profits by providing an exemption.

3 This physical presence requirement has a parallel within the U.S. subnational tax regime in the form of "nexus."

${ }^{4}$ See Figure 3 in IMF (2014).
} 


\section{Appendix III. Multilateral Measures-BEPS and ATAD}

\section{The BEPS Outcomes ${ }^{1}$}

In four areas there are minimum standards, the expectation being that domestic law and/or treaties will be amended so as to adopt them:

- To counter treaty shopping ${ }^{2}$ by including in treaties either limitation of benefit or more general principle purpose test provisions (see Appendix VII) so as to restrict access to benefits.

- On transfer pricing and country by country reporting, MNEs with group turnover over $€ 750$ million are to make available general information on their activities to all countries in which they are active, and to provide certain prescribed information on their assets, employees, pre-tax profit, and tax paid and accrued in each jurisdiction (shared by the parent country consistent with information exchange agreements).

- In relation to harmful tax practices, a particular focus on 'patent boxes' led to a 'nexus' principle that preferential regimes should only be offered conditional on substantial underlying activity (see Appendix VI); rulings that raises BEPS concerns are to be shared automatically.

- For dispute resolution, measures to ensure timely and good faith outcomes.

In some areas, guidance is captured by amendments to core OECD reference documents

- The definition of a permanent establishment in the OECD Model Tax Convention is widened so as to include, for instance, commissionaire arrangements (under which an agent undertakes sales without being the owner of the product) and to address avoidance of PE status by fragmentation of activities.

- On transfer pricing, the OECD Guidelines are amended, notably to address artificial transfer of risk within groups and difficulties associated with intangibles (clarifying that taxation need not follow legal ownership), and with some guidance in dealing with hard-to-value transactions.

In others, the outcome is guidance on a common approach, with an aspiration of convergence:

- On hybrid mismatch (the potential difficulty arising when an entity or instrument is regarded differently in different countries (debt in one, equity in the other, for instance), rules are envisaged to ensure that deductions not be given unless the associated income is taxable to the recipient (albeit possibly, as a matter of policy, at zero rate).

\footnotetext{
${ }^{1}$ Digitalization aspects are discussed in the text.

2 Meaning the artificial structuring of activities to exploit favorable treaty provisions such as low withholding tax rates: see Box 2 of IMF (2014).
} 
- Interest deductions to be limited to 10-30 percent of earnings before interest, taxes, depreciation and amortization (EBITDA), with carry forward of unused deductions or allowances; but with possibility of increasing deductions up to the group-wide ratio of interest to EBITDA.

- Recommendations are given on details of Controlled Foreign Corporation rules-to ensure, for instance, that tax is not inappropriately deferred and credit is given for any foreign taxes actually paid....

- ...and on provisions for mandatory disclosure of aggressive tax planning to enable the authorities to identify and address emerging risks.

Some recommendations, and the minimum standards in particular, will require domestic law reform and treaty changes. To facilitate this:

- The Inclusive Framework on BEPS was established to facilitate the implementation and monitoring of agreed BEPS measures. Data is being gathered to assess the impact of the global implementation of the BEPS measures, and a peer review process has already begun to ensure effective implementation of the minimum standards. Significant progress has been made on combatting harmful tax practices (255 preferential tax regimes have been examined, with 134 being revised or abolished), country by country reporting (over 1,800 reporting relationships have been established, with exchanges started in June 2018) and dispute resolution (with improved resolution of Mutual Agreement Procedure cases).

- A multilateral instrument was developed and entered into force on July 1, 2018 enabling simultaneously modification of covered treaties to combat treaty-based BEPS concerns such as treaty shopping once the ratifications of approximately 85 signatories become effective over time.

Further and ongoing work has been undertaken to flesh out various aspects of the broad BEPS outcomes, including: use of the transactional profit split method, application of the interest limitation rules for the banking and insurance sectors, and transfer pricing issues for commodities, hard to value intangibles and financial transactions. A series of 'toolkits' is being developed, by the $P C T$, including for application of some of the BEPS outcomes in the special circumstances of developing countries.

\section{The Anti-Tax Avoidance Directive (ATAD)}

The table below summarizes the main features of the ATAD, adopted in 2016, compared with the BEPS minimum standards. 


\begin{tabular}{|c|c|c|}
\hline \multicolumn{3}{|c|}{ Appendix Table 1. Key Features of ATAD } \\
\hline ATAD Measures & $\begin{array}{l}\text { BEPS Action/ } \\
\text { Minimum } \\
\text { Standard? }\end{array}$ & Description \\
\hline Interest limitation rule & Yes/No & $\begin{array}{l}\text { ATAD prescribes an earning-stripping rule that } \\
\text { denies interest deductions if the ratio of net } \\
\text { interest payments to EBITDA exceeds } 30 \text { percent. } \\
\text { Unused deductions can be carried forward. }\end{array}$ \\
\hline $\begin{array}{l}\text { Controlled foreign } \\
\text { company (CFC) rule }\end{array}$ & Yes/No & $\begin{array}{l}\text { EU member states must implement CFC } \\
\text { legislation in their national laws incorporating } \\
\text { certain legal design features. }\end{array}$ \\
\hline Hybrid mismatches rule & Yes/No & $\begin{array}{l}\text { This rule counters tax planning that exploits } \\
\text { differences in countries' legal characterization of } \\
\text { an entity or a financial instrument (leading to } \\
\text { double deductions or a deduction without an } \\
\text { equivalent income inclusion). The rule was } \\
\text { extended in March } 2017 \text { to also cover } \\
\text { arrangements between EU and non-member } \\
\text { states (ATAD II). }\end{array}$ \\
\hline GAAR & No/No & $\begin{array}{l}\text { Non-genuine arrangements that are put in place } \\
\text { for the main purpose of obtaining a tax } \\
\text { advantage that defeats the object or purpose of } \\
\text { the applicable law should be ignored when } \\
\text { determining a tax liability. }\end{array}$ \\
\hline Exit taxation & No/No & $\begin{array}{l}\text { EU member states must apply an exit tax to } \\
\text { prevent companies from avoiding tax in the } \\
\text { country of origin by moving their tax residence or } \\
\text { closing a PE. }\end{array}$ \\
\hline e: IMF staff compilation. & & \\
\hline
\end{tabular}




\section{Appendix IV. International Provisions of the TCJA}

1. Prior to reform, the U.S. taxed the worldwide income of U.S. MNEs, with a nonrefundable credit for foreign taxes paid, and liability to U.S. tax being deferred until dividends were paid from the foreign subsidiary to the U.S. parent. The TCJA now excludes from U.S. taxation active business income that is earned abroad, thus moving the system closer to those of other OECD economies. It also includes three novel measures of considerable importance to the current reform debate: ${ }^{1}$

- 'Global Intangible Low Taxed Income' (GILTI). As an important qualification of the move to territoriality, the TCJA imposes a minimum tax on overseas income. (Despite the name, GILTI income is not formally associated with intangible assets). This taxes at the 21 percent corporate rate the aggregate of the income of CFCs earned abroad that exceeds 10 percent of qualified business asset investment-but with a deduction for corporate recipients of 50 percent of that income. Credit is given for 80 percent of the foreign tax paid on such income. There is, however, no deferral of the tax and no link to repatriation of the income. This, in effect, imposes a minimum rate on GILTI income of 10.5 percent (if no tax is paid abroad) with tax liability to the U.S. wholly eliminated if the foreign tax on that income is at least 13.125 percent.

- 'Foreign Derived Intangible Income' (FDII). Domestic corporations receive a 37.5 percent deduction from the corporate tax base for 'FDII,' which is calculated as the income of the corporation in excess of 10 percent of qualified business asset investment multiplied by the ratio of foreign-derived income to total income (all calculated on a consolidated group basis). This effectively reduces the corporate tax rate from 21 to 13.125 percent for income arising from the sale of goods or services that are produced in the U.S., but sold to non-U.S. parties, to the extent that such income exceeds 10 percent of tangible assets.

- Base Erosion Anti-Abuse Tax (BEAT). This is a minimum tax in relation to inbound investment, applied to MNEs with annual gross receipts over US $\$ 500$ million in the preceding 3 years and making cross-border payments from the U.S. to affiliates of more than 3 percent of their total deductible expenses. The payments targeted are those (such as interest, royalties, and management fees) commonly associated with profit shifting. The provision does not apply to items characterized as cost of goods sold. ${ }^{2}$ Specifically, the BEAT imposes a tax liability that is the larger of (i) 10 percent (5 percent for 2018; 12.5 percent after 2025) on a concept of "modified" taxable income, which adds back into income those applicable deductions claimed for cross-border payments to affiliates that are not part of the costs of goods sold, or (ii) the regular tax liability (net of tax credits, with some exceptions) under the normal CIT base.

\footnotetext{
${ }^{1}$ These descriptions are highly simplified: the proposed GILTI regulations for example, run to 400 pages.

2 "Cost of goods sold" (COGS) generally includes: the cost of products or raw materials, including freight or shipping charges; costs of storage; direct labor costs; factory overhead expenses; and depreciation. The advent of BEAT puts more weight on whether certain costs are characterized as COGS for tax purposes.
} 


\section{Appendix V. Profit Shifting: Evidence and Opportunities}

1. The scale of profit shifting remains hard to assess. ${ }^{1}$ At the time of IMF (2014), there was much anecdote but little hard evidence. More has been learnt since. Damgaard and Elkjaer (2017), for example, estimate that around 40 percent of global FDI is routed through special purpose entities, which are often set up for tax avoidance purposes-with 85 percent of that in eight jurisdictions. There has also been much work on quantifying the revenue losses from profit shifting. ${ }^{2}$ Using differing methodologies, OECD (2015e) put the overall loss at an average 4-10 percent of CIT revenues in 2013; IMF (2014) put it at an (unweighted) average of about 5 percent. Results relating to $\mathrm{G}-7$ countries are summarized in Table 1.

\section{One robust conclusion is that profit shifting is especially important for developing} countries. This a central finding of IMF (2014) and Crivelli, de Mooij, and Keen (2016), which put the revenue loss to developing countries from profit shifting at 1.3 percent of GDP, which is larger than for OECD countries (Figure 1). Subsequent studies reach a similar conclusion. ${ }^{3}$

\section{The BEPS project has brought progress in addressing central opportunities for tax}

avoidance. 'Treaty shopping' is made harder by one of the BEPS minimum standards, supported by provisions in the MLI. The strengthened transfer pricing guidelines, including some increased emphasis on substance over form, and, perhaps most directly, the minimum standard on harmful tax practices, will go some way to impeding profit shifting. $\mathrm{CbC}$ reporting may give tax administrations a better understanding of the operations and structure of the MNEs with which they deal.

\section{Nonetheless, considerable opportunities for profit shifting remain-and may in some} respects be growing. ${ }^{4}$ The BEPS project sought to fix the most egregious abuses within, while preserving, the core international tax system. Not surprisingly, it has not fully resolved all the tensions inherent in it. First, while revisions to the transfer pricing guidelines dampen, they far from eliminate opportunities created by fundamental difficulties in applying the ALP to: 5

- Allocation of risk within MNEs. Companies may arrange to have internal financing provided, and risk apparently borne, by an entity located in a low tax jurisdiction. The essential problem this creates is not a practical one of how to apply the ALP to properly identify where that risk is

\footnotetext{
${ }^{1}$ Evidence on each of the principal channels of profit shifting is reviewed in Beer, de Mooij, and Liu (2018).

2 Some of the data and methodological issues are reviewed in Bradbury, Hannapi, and Moore (2018).

${ }^{3}$ Cobham and Jansky (2018) update Crivelli, de Mooij, and Keen (2016). Fuest, Hebous, and Riedel (2011) find tax effects on debt shifting twice as large in developing countries as in developed. Johannesen, Tørsløv, and Wier (2016) find that less developed countries are relatively more exposed to profit shifting, and Tørsløv, Wier, and Zucman (2018) that developing countries are the prime losers from global profit shifting, with reported revenue losses of around 20 percent. Looking at profit shifting in oil and gas, Beer and Loeprick (2017) report larger effects for LICs.

${ }^{4}$ For fuller discussion, see Avi-Yonah and Xu (2017) and Collier and Andrus (2017). Lane and Milesi-Ferretti (2017) report that the significant growth in FDI since the Global Financial Crisis is due to routing through special purpose vehicles and likely driven by tax considerations.

${ }^{5}$ Wei (2018).
} 
located: it is a conceptual difficulty with the notion that it can meaningfully be allocated anywhere within the MNE, when it is ultimately borne only by the final shareholders and external creditors of the MNE itself. For many economists, attempts to use the ALP (or any other method) to allocate risk within a MNE are inherently incoherent.

- The valuation of intangibles (such as patents, brand names, goodwill) which are relatively easy to relocate to, or create in, low tax jurisdictions. Valuation is commonly needed of both their asset value (since any capital gain on their transfer will generally be payable) and of the associated income (generating deduction where paid, and income where received). In this case, it is the application of the ALP that is the difficulty. By their nature, valuable intangible assets commonly have a uniqueness which means that there are unlikely to be closely comparable transactions between independent parties by which they can be assessed, and when transfer occurs there are likely to be considerable asymmetries of information as to potential value between the company owning the intangible and the tax administration. ${ }^{6}$

- Two-sided markets of the kind central to the digitalization debate. ${ }^{7}$

\section{Difficulties also arise from:}

- The ease of avoiding or limiting a presence creating a right to tax. The definition of a PE has been tightened, but increased ability to do business remotely has made it easier to avoid a taxable presence or to limit it to operations to which the ALP will allocate relatively little income. Intra-group services also raise challenges for which the traditional PE concept has proven insufficient. To protect source countries against such base eroding payments, the 2017 UN Model Tax Convention includes a new technical service fee article-though it remains to be seen whether developing countries will be successful in negotiating its inclusion in their DTAs.

Appendix Table 1 summarizes issues within the current architecture, how the BEPS measures address some of them, and remaining vulnerabilities. ${ }^{8}$

\footnotetext{
${ }^{6}$ Value can be observed ex post, but inferring the ex-ante value requires also information on the probability of that outcome occurring.

${ }^{7}$ See Wei (2018).

${ }^{8}$ The latter include, for example, two issues taken up in Appendix VII, related to offshore indirect transfers of interest and service and management charges.
} 


\begin{tabular}{|c|c|c|c|}
\hline \multicolumn{4}{|c|}{ Appendix Table 1. BEPS Impact on International Concepts and Norms for International Tax Law Design } \\
\hline International concept and norm /1 & $\begin{array}{l}\text { Gap or mismatch being } \\
\text { exploited }\end{array}$ & BEPS focus & $\begin{array}{l}\text { Remaining deficiencies and weaknesses } \\
\text { after BEPS }\end{array}$ \\
\hline $\begin{array}{l}\text { Residents are taxed on worldwide income } \\
\text { (residence principle) and non-residents are } \\
\text { taxed on domestic source income (source } \\
\text { principle). }{ }^{1}\end{array}$ & $\begin{array}{l}\text { Ability to strip and shift profits out } \\
\text { of high tax (residence or source) } \\
\text { countries (e.g. through base } \\
\text { eroding payments such as interest } \\
\text { deductions or profit shifting by } \\
\text { minimizing assets/risks in those } \\
\text { high tax countries). }\end{array}$ & $\begin{array}{l}\text { BEPS (e.g. Actions 2, } 4 \text { and } \\
\text { 8-10) directed at: limiting base } \\
\text { erosion through interest and } \\
\text { other deductions; neutralizing } \\
\text { the (deduction) effects of } \\
\text { hybrid mismatch arrangements; } \\
\text { and seeking to align transfer } \\
\text { pricing outcomes with value } \\
\text { creation. }\end{array}$ & $\begin{array}{l}\text { Other base eroding payments (e.g. cross- } \\
\text { border service or management fees) are } \\
\text { unaddressed, and intangible and risk related } \\
\text { returns are still capable of being shifting to } \\
\text { low tax jurisdictions using ALP (see below). }\end{array}$ \\
\hline $\begin{array}{l}\text { The source country has the primary right to } \\
\text { tax active income, subject to finding a } \\
\text { sufficient economic presence (nexus), } \\
\text { defined by reference to a permanent } \\
\text { establishment (PE) in its jurisdiction. }\end{array}$ & $\begin{array}{l}\text { Weakness of existing nexus } \\
\text { requirement exacerbated by } \\
\text { digitalization because a PE does } \\
\text { not arise when businesses sell } \\
\text { remotely from abroad, even } \\
\text { though there is a significant } \\
\text { internet and economic presence in } \\
\text { a local market. }\end{array}$ & $\begin{array}{l}\text { BEPS (e.g. Action 7) directed } \\
\text { only at preventing the artificial } \\
\text { avoidance of (physical) PE. }\end{array}$ & $\begin{array}{l}\text { No fundamental change to nexus test, which } \\
\text { has focused attention on the fairness of } \\
\text { existing allocation of taxing rights, particularly } \\
\text { in the context of digitalization. }\end{array}$ \\
\hline $\begin{array}{l}\text { The residence country has the primary right } \\
\text { to tax passive income (other than from } \\
\text { immovable property in source country), with } \\
\text { the source country typically accepting rate } \\
\text { limits on locally sourced passive income } \\
\text { (e.g. by entering into DTAs). }\end{array}$ & $\begin{array}{l}\text { Engaging in treaty shopping or } \\
\text { arbitrage of domestic tax rules to } \\
\text { achieve low or no withholding tax } \\
\text { on payments made from source } \\
\text { country. }\end{array}$ & $\begin{array}{l}\text { BEPS (e.g. Action 6) directed at } \\
\text { preventing the granting of } \\
\text { treaty benefits in inappropriate } \\
\text { circumstances. }\end{array}$ & $\begin{array}{l}\text { Reduced source country taxation under DTA } \\
\text { not otherwise dependent on being subject to } \\
\text { a minimum level of taxation. }\end{array}$ \\
\hline $\begin{array}{l}\text { Residence country taxation of foreign } \\
\text { income is deferred until repatriation, unless } \\
\text { controlled CFC rules apply to combat } \\
\text { inappropriate deferral. }\end{array}$ & $\begin{array}{l}\text { Ability to achieve inappropriate tax } \\
\text { deferral by exploiting the absence } \\
\text { of (effective) CFC rules. }\end{array}$ & $\begin{array}{l}\text { BEPS (e.g. Action 3) directed at } \\
\text { designing effective CFC rules. }\end{array}$ & $\begin{array}{l}\text { Residual profit still capable of being shifted to } \\
\text { low tax jurisdictions using arm's length } \\
\text { principle, and often left untaxed by CFC rules. }\end{array}$ \\
\hline $\begin{array}{l}\text { The residence country provides relief from } \\
\text { international double taxation, either through } \\
\text { domestic law or DTAs, typically by way of a } \\
\text { credit or exemption method. }\end{array}$ & $\begin{array}{l}\text { Trend towards territorial system of } \\
\text { taxation in residence countries } \\
\text { enables residual profit shifted to } \\
\text { low tax jurisdictions to remain } \\
\text { untaxed. }\end{array}$ & $\begin{array}{l}\text { Not specifically dealt with by } \\
\text { BEPS and often left untaxed by } \\
\text { CFC rules. }\end{array}$ & $\begin{array}{l}\text { Tax competition not fundamentally addressed } \\
\text { (e.g. no or nominal tax jurisdictions), with ALP } \\
\text { still enabling substance (assets/risks) to be } \\
\text { shifted to justify the location of large residual } \\
\text { profits in low-tax jurisdictions. }\end{array}$ \\
\hline $\begin{array}{l}\text { Income is allocated between jurisdictions } \\
\text { based on the ALP. }\end{array}$ & $\begin{array}{l}\text { Ability to produce transfer pricing } \\
\text { outcomes that do not align with } \\
\text { value creation. }\end{array}$ & $\begin{array}{l}\text { BEPS (e.g. Actions } 8-10 \text { ) } \\
\text { seeking to align transfer pricing } \\
\text { outcomes with value creation. }\end{array}$ & $\begin{array}{l}\text { Intangible and risk related returns still capable } \\
\text { of being shifted to low or nominal tax } \\
\text { jurisdictions, exacerbated by unconstrained } \\
\text { tax competition. }\end{array}$ \\
\hline
\end{tabular}

Note: $1 /$ Some countries have pure territorial systems: that is, time tax only on a source basis. 


\section{Appendix VI. Tax Competition}

1. Revenue is eroded by tax competition between countries, whether intended to attract real activities or paper profits. Such competition is manifested most obviously by a decline in statutory CIT rates (Figure 2), but other devices—such as the provision of favorable tax treatment for highly mobile income related to payment for the use of patents-have also been prominent. Many avoidance devices can be seen as having been created to attract tax base. Some have argued that such tax competition may be beneficial, by constraining governments otherwise inclined to waste resources. ${ }^{1}$ That argument is now less common, perhaps reflecting both an enhanced focus on revenue-raising since the Global Financial Crisis and a recognition that fiscal rules offer the possibility of constraining public spending without imposing potentially inefficient or inequitable tax policies. A somewhat more telling (if politically awkward) argument in favor of the existence of low tax jurisdictions that tax competition tends to produce is that they provide a way by which firms most subject to distortion from heavy taxation can reduce the excess burden they suffer. ${ }^{2}$

\section{Making avoidance harder could result in tax competition becoming more intense and} damaging-particularly for real investments. Closing only some avenues for avoidance can lead to more intense use of others. ${ }^{3}$ If all avoidance possibilities were closed and tax effectively levied only 'where value is created', and the location of that value creation is mobile, then the result can be expected to be tax competition aimed at attracting those value-creating activities. ${ }^{4}$

\section{Such collective efforts as there have been to address tax competition have focused on} identifying and removing specific practices regarded as having harmful spillover effects. Common minimum rates have sometimes been proposed for regional groupings, but rarely implemented: 5 WAEMU and CEMAC appear to be the only examples of international agreements on a minimum CIT rate (at 25 percent). ${ }^{6}$ Collective approaches to easing tax competition-beginning with OECD (1998) and the establishment of the Code of Conduct group on Business Taxation in the EU (1997) - have focused not on general levels of corporate taxation but on precluding certain practices identified as harmful (the same is true, implicitly, of the EU state aid rules). Low or no effective taxation has thus been seen not as inherently harmful in itself.

\footnotetext{
${ }^{1}$ Notably Brennan and Buchanan (1980).

2 The possible benefits of this are developed by Hong and Smart (2010); and its empirical relevance shown by the finding of de Mooij and Liu (2018) that effective anti-avoidance measures can lead to lower levels of real investment.

3 Saunders-Scott (2015).

${ }^{4}$ Becker and Fuest (2012) show how more restrictive transfer pricing rules can lead to more aggressive tax competition; more generally, see Keen (2018).

${ }^{5}$ An early example was the proposal of the Ruding Committee (Commission of the European Communities, 1992) for a minimum CIT rate in the EU of 30 percent.

${ }^{6}$ Combined with a maximum of 30 percent in WAEMU and 40 percent in CEMAC.
} 
4. This approach has come to center on precluding preferential regimes with little requirement of substantial activity. BEPS and the EU Code of Conduct ${ }^{7}$ identify measures as harmful if, broadly, they provide preferential tax treatment without requiring a significant real presence ('nexus') in the jurisdiction. ${ }^{8}$ Refraining from such regimes is a BEPS minimum standard; the EU applies the test to real as well as financial activities and to non-members by listing of noncooperative jurisdictions.

\section{The theoretical case for identifying preferential regimes as inherently harmful is} uneasy, and substance requirements can be problematic. Requiring countries to tax all activities, however mobile, in the same way can make tax competition even more harmful. This is because countries may choose, if prevented from setting differential rates, to switch from charging a high rate on less mobile activities and a low rate on more mobile ones to charging some intermediate rate on all activities - and the spillover from the rate cut element of that may damage other countries more than the rate increase element benefits them. ${ }^{9}$ The circumstances in which this will be the dominant effect have yet to be fully understood. ${ }^{10}$ Nonetheless, the BEPS minimum standard is consistent with this thinking in implicitly recognizing that differential treatment is not intrinsically harmful. One difficulty is the risk that the substance can be created artificially by inefficient allocation of production factors. Recently, OECD have sought to overcome the potentially perverse that a higher rate attached to a scheme which does not pass the nexus test would be harmful while a uniform very low CIT rate is not.

\section{Whether low or zero tax rates should be regarded as per se harmful is increasingly} coming to the fore. There would be some logic in doing so-so long as source-based taxes substantially determine overall liability—but also considerable conceptual, practical, and political obstacles. Conceptually, any spillover effects from CIT choices need to be weighed against domestic considerations, which for some countries (such as those rich in natural resources) may reasonably point to low/zero general tax rates. Practically, agreement would also be needed on tax bases to prevent low or zero effective tax rates being achieved by base narrowing. ${ }^{11}$ Politically, the choice of national CIT rates continues to be seen as a core aspect of national sovereignty.

\footnotetext{
${ }^{7}$ As set out in respectively OECD (2015mm) and European Council (1998).

8 This was largely in reaction to 'IP' or 'patent' box regimes providing favorable treatment of related income even if the development had occurred elsewhere. But the principle is now applied more generally: BEPS Action 5 requires "...an adequate number of full-time employees with necessary qualifications and incurring an adequate amount of operating expenditure to undertake such activities."

${ }^{9}$ The classic example is that of Ireland, which, under pressure from the EU, moved between 1999 and 2005 from the combination of a general CIT rate of 32 percent and a preferential rate of 10 percent to a single rate of 12.5 percent.

10 On this, see Keen and Konrad (2013). Domestically, differential treatment does, however, bring its own distortions, can create problems of profit shifting between wholly domestic enterprises and can raise significant governance issues: see IMF, OECD, World Bank and UN (2015).

${ }^{11}$ The relevant WAEMU and CEMAC directives, for example, include restrictions on the CIT base-but even that may not be enough: tax competition in WAEMU, for instance, has flourished outside the areas of agreement (Mansour and Rota-Graziosi, 2013).
} 


\title{
Appendix VII. Some Developments Concerning Developing Countries
}

\author{
There has been some progress in each of the four areas that IMF (2014) identified as \\ especially important to developing countries:
}

- Double tax agreements (DTAs) continue to impose revenue risks for developing countries. They generally limit some source taxing rights in the hope of attracting FDI. IMF (2014) reported mixed evidence on FDI effects. More recent studies confirm this ambiguity ${ }^{1}$ and suggest that the effect depends on countries' overall treaty networks and specific provisions in the DTAs. On the revenue impact, however, the evidence has grown still stronger that the losses for developing countries can be significant: Beer and Loeprick (2018) estimate that the ability of MNEs to reroute their intra-group payments to exploit favorable treaty arrangements with 'investment hubs has reduced CIT revenues in Sub Saharan African countries by around 15 percent.

Countries are now increasingly seeking to adopt treaty anti-abuse provisions to counter treaty shopping. The MLI offers a potentially efficient way to modify existing treaties so as to do this, consistent with the BEPS minimum standard, by adopting safeguard provisions in the form of a principle purposes test (PPT) and/or limitation of benefits (LOB) provision. ${ }^{2}$ As with all provisions under the $\mathrm{MLI}$, however, the effectiveness of this depends on agreement with treaty partners: if the treaty partner makes a reservation in the MLI to a certain provision that a country wishes to change, there is no modification to that aspect of the treaty. And preferred approaches differ. ${ }^{3}$

More generally, other problematic areas in developing countries' DTAs, such as maximum withholding tax rates, key elements of the PE definition and service fees require a separate process of renegotiation as they are not covered by the MLI.

- Taxation of capital gains on offshore indirect transfers of interest in assets (OITs). The issue, which arises in relation to immovable property and potentially more broadly to telecoms, mineral and other licenses, is the potential for companies to avoid liability to tax on a capital gain associated with some underlying asset where that asset is located by realizing that gain through the sale in a low tax jurisdiction of a company holding that asset indirectly. This has emerged in IMF TA as a macro-relevant concern in many low-income countries, particularly

\footnotetext{
${ }^{1}$ Three recent studies find no effect of treaties on FDI (Baker, 2014; Daniels, O'Brien, and von der Ruhr, 2015; Beer and Loeprick, 2018); three find a positive effect (Marques and Pinho, 2014; Van 't Riet and Lejour, 2017; Hong 2018).

2 Under a PPT, broadly speaking, treaty benefit is denied if one of the main purposes of an arrangement is to obtain those benefits; an LOB seeks to limit tax treaty benefits to genuine residents of the other contracting state.

${ }^{3}$ Advanced economies seem to opt for the (more complex to enforce) PPT, rather than the LOB, far more often than emerging economies.
} 
those with natural resources. Domestic laws and treaties of many developing countries need strengthening if they are to tax gains on OITs.

Since 2014, the PCT has developed guidance on how source countries can secure taxing rights on such transfers. ${ }^{4}$ Importantly, the $\mathrm{MLI}$ allows for adoption of a key treaty provision to secure taxing rights of OIT in the source country (Article 13.4). As of December 2018, however, of the 85 MLI signatories, it appears that 44 (mainly advanced) countries have reserved on this provision.

- Interest deduction limitations can usefully curb base erosion through debt shifting and are a standard recommendation in IMF TA. By 2014, 28 developing countries had thin capitalization rules in place (IMF 2016); since then, at least six more have adopted such rules. A common approach is to use a debt/equity ratio to determine the proportion of interest that will be denied for deduction. BEPS Action 4 endorses a new approach based on an interest/earnings ratio. ${ }^{5}$ All thin cap rules, however, have an element of arbitrariness, potentially deterring investment through their impact on non-abusive arrangements. The interest stripping rule, for instance, can unduly pressure firms with temporarily low earnings (with adverse cyclical effects) or with firmspecific characteristics enabling them to bear more debt. Action 4 therefore allows complementary provisions, such as a group escape (which undoes the deduction limitation if the company's ratio remains below that of consolidated group) and a carry forward provision for unused interest. These complementary measures may, however, be hard for LICs to implement. More fundamentally, the problems of artificial debt shifting and perhaps debt bias linger.

- Transfer pricing rules aim to limit profit shifting through transfer mispricing by, among others, prescribing agreed methods and reporting requirements. In 2012, 34 developing countries had transfer pricing rules in place; ${ }^{6}$ Over the last 5 years, 17 African countries adopted such rules. ${ }^{7}$ But transfer pricing practice can be extraordinarily complex, and is not made less so by BEPS. The guidance provided by the PCT (2017) on the application of ALP in circumstances of the kind likely faced by developing countries, for instance-supplementing the BEPS material itself-runs to 237 pages. Developing countries continue to face significant difficulty in enforcing transfer pricing regulations and, for example, challenging the transfer prices used by MNEs.

Country-by-country $(\mathrm{CbC})$ reporting-a BEPS minimum standard-could help LIC tax authorities in their transfer-pricing risk assessments (although a transfer pricing adjustment cannot be based on a $\mathrm{CbC}$ report alone). Further information will still be needed (on, for instance, profit drivers, functional analysis, ownership structures, and intangibles), however, to apply ALP; and the skills to perform the corresponding audits are demanding. LICs may, moreover, have difficulty meeting the required standards for data protection and other conditions for the exchange of $\mathrm{CbC}$ information needed if they are to be able to access $\mathrm{CbC}$ reports.

\footnotetext{
4 Platform for Collaboration on Tax (2019).

5 This is not, however, a minimum standard.

6 De Mooij and Liu (2018).

7 Piccioto (2018).
} 


\begin{tabular}{|c|c|c|c|c|c|c|c|c|}
\hline & $\begin{array}{l}\text { European } \\
\text { Commission }\end{array}$ & France /1 & Italy & U.K. & Chile & India & Uruguay & $\frac{7}{0}$ \\
\hline $\begin{array}{l}\text { Date of } \\
\text { introduction }\end{array}$ & $\begin{array}{l}\text { Proposal issued } \\
\text { in March 2018; } \\
\text { modified } \\
\text { November } 2018 .\end{array}$ & $\begin{array}{l}\text { Jan 1, } 2018 \\
\text { (Decree No. 2017-1364; } \\
\text { Sep 20, 2017) }\end{array}$ & $\begin{array}{l}\text { Jan 1, } 2019 \\
\text { (Budget Law } \\
\text { 2018, Law 205) }\end{array}$ & $\begin{array}{l}\text { Apr 6, } 2020 \\
\text { (Finance Bill } \\
\text { 2019/20) }\end{array}$ & $\begin{array}{l}\text { Proposal issued } \\
\text { Aug 23, } 2018\end{array}$ & $\begin{array}{l}\text { Jan 1, } 2016 \\
\text { (Finance Act } \\
\text { 2016, Chapter } \\
\text { VIII) }\end{array}$ & $\begin{array}{l}\text { Jan 1, } 2018 \\
\text { (Law 19.535; } \\
\text { Resolution } \\
6,409 / 2018)\end{array}$ & $\underline{\underline{2}}$ \\
\hline Tax Rate & 3 percent & $\begin{array}{l}2 \text { percent; (10 percent } \\
\text { for certain content) }\end{array}$ & 3 percent & 2 percent & 10 percent & 6 percent & 12 percent / 2 & $\frac{0}{6}$ \\
\hline $\begin{array}{l}\text { Thresholds/ } \\
\text { Exemptions } \\
\text { for in-scope } \\
\text { businesses }\end{array}$ & $\begin{array}{l}\text { Annual } \\
\text { worldwide } \\
\text { revenues > EUR } \\
750 \text { million; and } \\
\text { Annual EU-wide } \\
\text { taxable revenues } \\
>\text { EUR } 50 \text { million. }\end{array}$ & $\begin{array}{l}\text { Tax free allowance of } \\
\text { EUR 100,000 for } \\
\text { provider of free online } \\
\text { access to Audiovisual } \\
\text { (AV) content, } 4 \text { percent } \\
\text { allowance for } \\
\text { advertising revenues, } \\
66 \text { percent allowance } \\
\text { for EU platforms } \\
\text { sharing content created } \\
\text { by private users, and } \\
\text { exemption for sites } \\
\text { where AV content is } \\
\text { not primary business. }\end{array}$ & $\begin{array}{l}\text { Tax payable by } \\
\text { businesses } \\
\text { with more } \\
\text { than } 3,000 \\
\text { digital } \\
\text { transactions } \\
\text { annually. }\end{array}$ & $\begin{array}{l}\text { Annual } \\
\text { worldwide in- } \\
\text { scope revenues } \\
\text { > GBP } 500 \\
\text { million; and } \\
\text { Annual U.K. in- } \\
\text { scope revenue } \\
\text { > GBP } 25 \\
\text { million } \\
\text { Safe harbor } \\
\text { provisions for } \\
\text { loss-makers and } \\
\text { businesses with } \\
\text { low margins. } \\
\text { Annual GBP } 25 \\
\text { million tax-free } \\
\text { threshold. }\end{array}$ & Not specified. & $\begin{array}{l}\text { Aggregate } \\
\text { payments to } \\
\text { non-resident > } \\
\text { INR } 100,000 \\
\text { (approx. US\$ } \\
1500 \text { ) in a } \\
\text { financial year. }\end{array}$ & $\begin{array}{l}\text { In the case of } \\
\text { intermediation } \\
\text { services, the } \\
\text { tax base will } \\
\text { be } 50 \text { percent } \\
\text { of the } \\
\text { transaction if } \\
\text { only one of } \\
\text { the parties is } \\
\text { based in } \\
\text { Uruguay. }\end{array}$ & 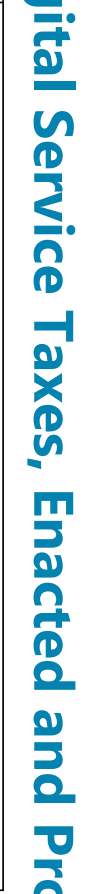 \\
\hline
\end{tabular}




\begin{tabular}{|c|c|c|c|c|c|c|c|}
\hline $\begin{array}{l}\text { Taxable } \\
\text { person(s) }\end{array}$ & All companies. & All companies. & $\begin{array}{l}\text { Non-resident } \\
\text { companies. } \\
\text { Withheld by } \\
\text { payer. }\end{array}$ & All companies. & $\begin{array}{l}\text { Non-resident } \\
\text { companies. } \\
\text { Withheld by } \\
\text { payment } \\
\text { intermediaries. }\end{array}$ & $\begin{array}{l}\text { Non-resident } \\
\text { companies. } \\
\text { Withheld by } \\
\text { payer. }\end{array}$ & Non-resident. \\
\hline $\begin{array}{l}\text { In-scope } \\
\text { activities }\end{array}$ & $\begin{array}{l}\text { Online } \\
\text { advertising, } \\
\text { digital } \\
\text { intermediation } \\
\text { services, sale of } \\
\text { data generated } \\
\text { by users. }\end{array}$ & $\begin{array}{l}\text { Sales and rentals of } \\
\text { video storage media, } \\
\text { videos on demand, and } \\
\text { advertising and } \\
\text { sponsorship revenues } \\
\text { derived by paid-for or } \\
\text { free online video sites. }\end{array}$ & $\begin{array}{l}\text { Digital services } \\
\text { supplied via } \\
\text { the internet or } \\
\text { other } \\
\text { networks. }\end{array}$ & $\begin{array}{l}\text { Search engines, } \\
\text { social media } \\
\text { platforms and } \\
\text { online } \\
\text { marketplaces. }\end{array}$ & $\begin{array}{l}\text { Digital } \\
\text { brokering, } \\
\text { advertising, } \\
\text { entertainment, } \\
\text { intermediation, } \\
\text { and storage } \\
\text { services. }\end{array}$ & $\begin{array}{l}\text { Online } \\
\text { advertising } \\
\text { purchased by } \\
\text { Indian buyers. }\end{array}$ & $\begin{array}{l}\text { AV services } \\
\text { and digital } \\
\text { mediation or } \\
\text { intermediation } \\
\text { services. }\end{array}$ \\
\hline $\begin{array}{l}\text { Taxable } \\
\text { revenues }\end{array}$ & $\begin{array}{l}\text { Portion of annual } \\
\text { worldwide } \\
\text { revenues } \\
\text { attributable to EU } \\
\text { users. /3 }\end{array}$ & $\begin{array}{l}\text { Revenues received from } \\
\text { French residents. }\end{array}$ & $\begin{array}{l}\text { Revenues } \\
\text { received from } \\
\text { Italian } \\
\text { residents or } \\
\text { Italian PEs of } \\
\text { non-residents } \\
\text { (B2B). }\end{array}$ & $\begin{array}{l}\text { Portion of } \\
\text { annual } \\
\text { worldwide } \\
\text { revenues } \\
\text { attributable to } \\
\text { U.K. users. } / 4\end{array}$ & $\begin{array}{l}\text { Revenues } \\
\text { received from } \\
\text { Chilean } \\
\text { consumers } \\
\text { (B2C). }\end{array}$ & $\begin{array}{l}\text { Revenues } \\
\text { received from } \\
\text { Indian } \\
\text { residents or } \\
\text { Indian PEs of } \\
\text { non-residents. }\end{array}$ & $\begin{array}{l}\text { Revenues } \\
\text { received from } \\
\text { Uruguayan } \\
\text { residents } \\
\text { (Uruguay- } \\
\text { based IP } \\
\text { address or } \\
\text { user billing } \\
\text { address). }\end{array}$ \\
\hline \multicolumn{8}{|c|}{$\begin{array}{l}\text { Notes: } 1 / \text { Germany has a similar tax with proceeds earmarked for the promotion of national cinema. } \\
\text { 2/ Constitutes an expanded scope of the existing non-resident income tax on Uruguayan-sourced income. Similar rules apply to the extended scope of the VAT. } \\
\text { 3/ Revenue allocation in proportion to (i) the number of times an advertisement has appeared on EU users' devices; (ii) the number of EU users having } \\
\text { concluded underlying transactions on a digital interface, with user location to be determined based on Internet Protocol (IP) addresses. } \\
\text { 4/ Revenue allocation in proportion to (i) for social media platforms, revenues from targeting adverts at U.K. users, (ii) for search engines, revenues from } \\
\text { displaying advertising against the result of key search terms inputted by UK users; (iii) for online marketplaces, commissions generated by facilitating a } \\
\text { transaction between U.K. users. }\end{array}$} \\
\hline
\end{tabular}




\section{Appendix IX. Revenue Implications of Formula Apportionment}

\section{This appendix explores the impact of various FA schemes on national corporate tax}

bases, using two datasets. It first uses aggregate data on the major affiliates of U.S. MNEs in 52 countries from the Bureau of Economic Analysis (BEA). ${ }^{1}$ It then uses firm-level data from ORBIS, covering 7,772 global MNE groups with 58,345 subsidiaries; this also enables estimation of the change in the MNE tax base due to cross-border loss consolidation. In both datasets, the countries covered are high-income and middle-income economies; only two low-income countries are covered in the BEA data (Honduras and Nigeria) and only one has sufficient data in ORBIS (Kyrgyz Republic).

\section{Aggregate U.S. MNE Data}

\section{Data for U.S. MNEs is first used to compare the current tax base with that under FA.}

The BEA publishes annual data on the aggregate finances and operations of U.S. based MNEs, separately reporting statistics for U.S. parent companies and their foreign affiliates in a large set of countries. The variable 'economic profit' is used as a proxy for the corporate tax base of U.S. MNEs: it measures operating income, excluding capital gains and losses and income from equity investments (which are usually exempt, to avoid double taxation). The unitary tax base under FA is calculated as the sum of economic profits in the U.S. and all countries in which U.S. MNEs operate. Denoting economic profit of affiliates in country $i$ by $\pi_{i}$, aggregate consolidated profits earned by all U.S. MNEs is thus:

$$
\pi=\sum_{i} \pi_{i}
$$

\section{The aggregate unitary tax base $\pi$ is allocated using alternative apportionment}

formulas. For this purpose, data are used for the share of each country's affiliate sales (on a destination basis), ${ }^{2}$ value added, fixed assets (defined as gross property, plant and equipment), payroll, or employment, with the share of the latter, for instance, defined as:

$$
\alpha_{\text {employment }, i}=\frac{e m p_{i}}{\sum_{i} e m p_{i}}
$$

\footnotetext{
1 This exercise differs from that in IMF (2014) in: (i) using more recent data for 2015, which expands the number of countries from 29 to 52; (ii) using a different indicator for economic profit, which excludes foreign earned income from the tax base (as this income is generally exempt from tax); (iii) exploring more weighting schemes, including sales by destination (instead of origin), value added, a Cobb-Douglas formula and the CCCTB formula.

${ }^{2}$ This means sales to unaffiliated persons that can be attributed to the country of the purchaser. For about 10 percent of offshore sales to unaffiliated persons, the destination country is not specified in the BEA data. For those sales, we assume they are proportionally attributed to the known distribution of sales to non-US countries.
} 
Apart from weighting schemes with only one factor, we also explore two multiple-factor formulas. The first, 'Cobb-Douglas' (CD) formula, combines asset and payroll shares-to roughly reflect the shares of capital income and labor income in aggregate value added:

$$
\alpha_{C D, i}=\frac{1}{3} \alpha_{\text {assets }, i}+\frac{2}{3} \alpha_{\text {payroll }, i} .
$$

The second multiple-factor formula is that used in the CCCTB proposal for the EU:

$$
\alpha_{\text {CССТ }, i}=\frac{1}{3} \alpha_{\text {assets }}+\frac{1}{3} \alpha_{\text {sales }}+\frac{1}{3} \cdot\left(\frac{1}{2} \alpha_{\text {payroll }}+\frac{1}{2} \alpha_{\text {employment }}\right)
$$

\section{The change in the tax base is measured as the difference between the simulated} economic profit under FA, and the reported economic profit in the BEA data. This is done for each of the seven weighting schemes $(f)$ above:

$$
\Delta \text { Base }_{f, i}=\alpha_{f, i} \cdot \pi-\pi_{i}
$$

Since $\pi=\sum_{i} \pi_{i}$ and $\sum_{i} \alpha_{f, i}=1, \sum_{i} \Delta$ Base $_{f, i}=0$ : the change in the aggregate global tax base of U.S. MNEs is zero: FA only redistributes that base across countries. This ignores the impact of crossborder loss consolidation, which is analyzed further below with the firm-level data.

5. For many countries, the tax base under FA is markedly different from the current. The estimated base changes (in percent of GDP) from FA for individual economies under each of the seven formulas are shown in Appendix Figures 1 and 2. Appendix Figure 1 ranks economies according to the base effect under the value-added formula (red dots), ranging from the largest base expansion at the top to the largest base reduction at the bottom. Beyond the general observations made in the text, it is worth noting that the effects under different weighting schemes are generally broadly similar. For instance, several countries find an expansion of their tax base, regardless of the apportionment factor. The effects of apportioning by employment differ across countries quite widely: some middle-income and low-income countries gain considerable base while some high-income countries lose. Using destination-based sales as the single formula factor benefits several middle-income countries. 


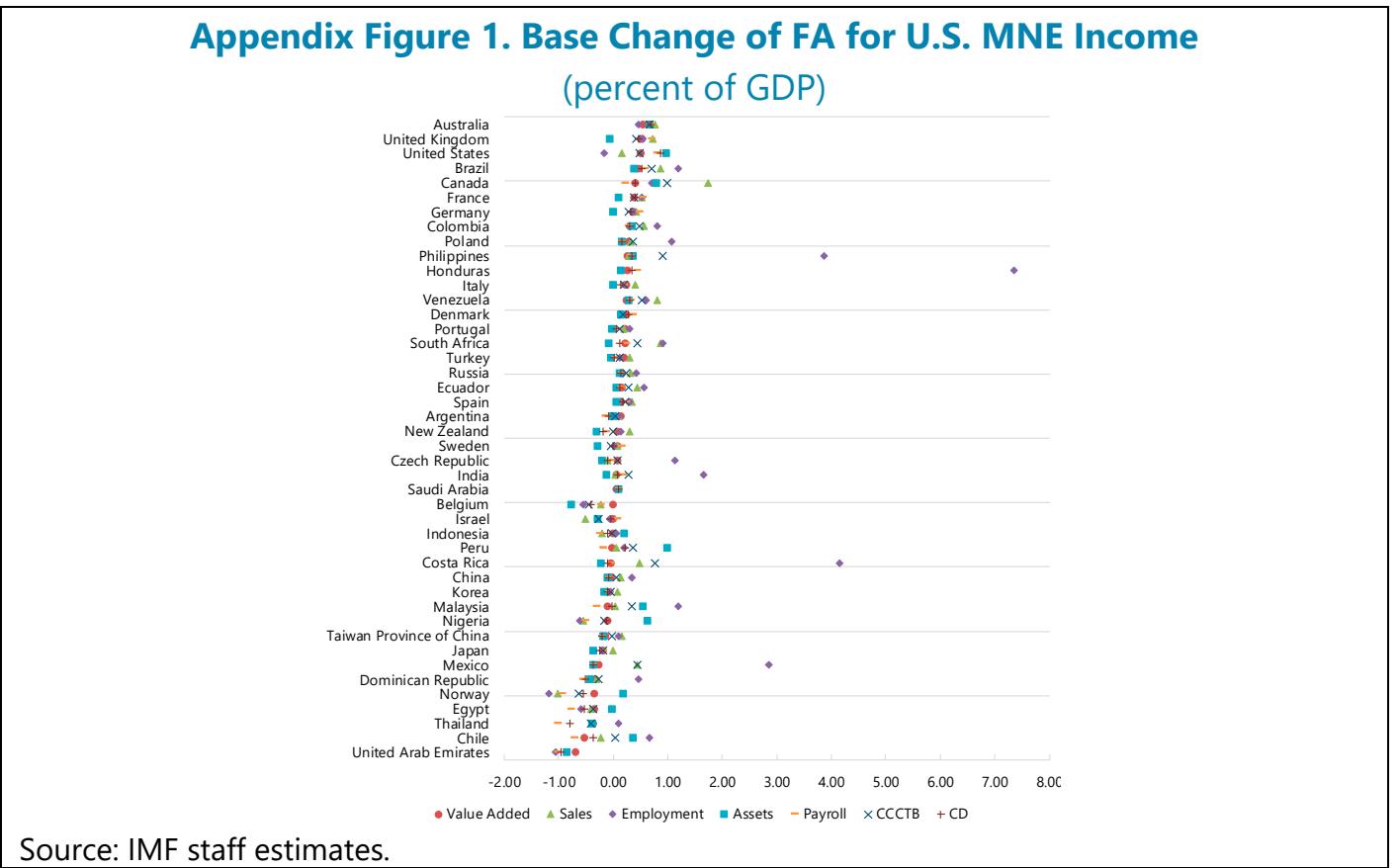

6. Investment hubs stand to lose from FA. Appendix Figure 2 shows the effects for eight economies with comparatively high ratios of FDI to GDP due to their relatively attractive tax regimes: 'investment hubs' (Dalgaard and Elkjaer 2017). These economies find their tax base significantly reduced under FA, whatever the formula used: the erosion of the tax base can even exceed 100 percent of GDP under some formulas. These results illustrate the large difference between the currently reported profits by U.S. MNEs in these economies and reported factor share used in the FA calculation to apportion global profits of these MNEs.

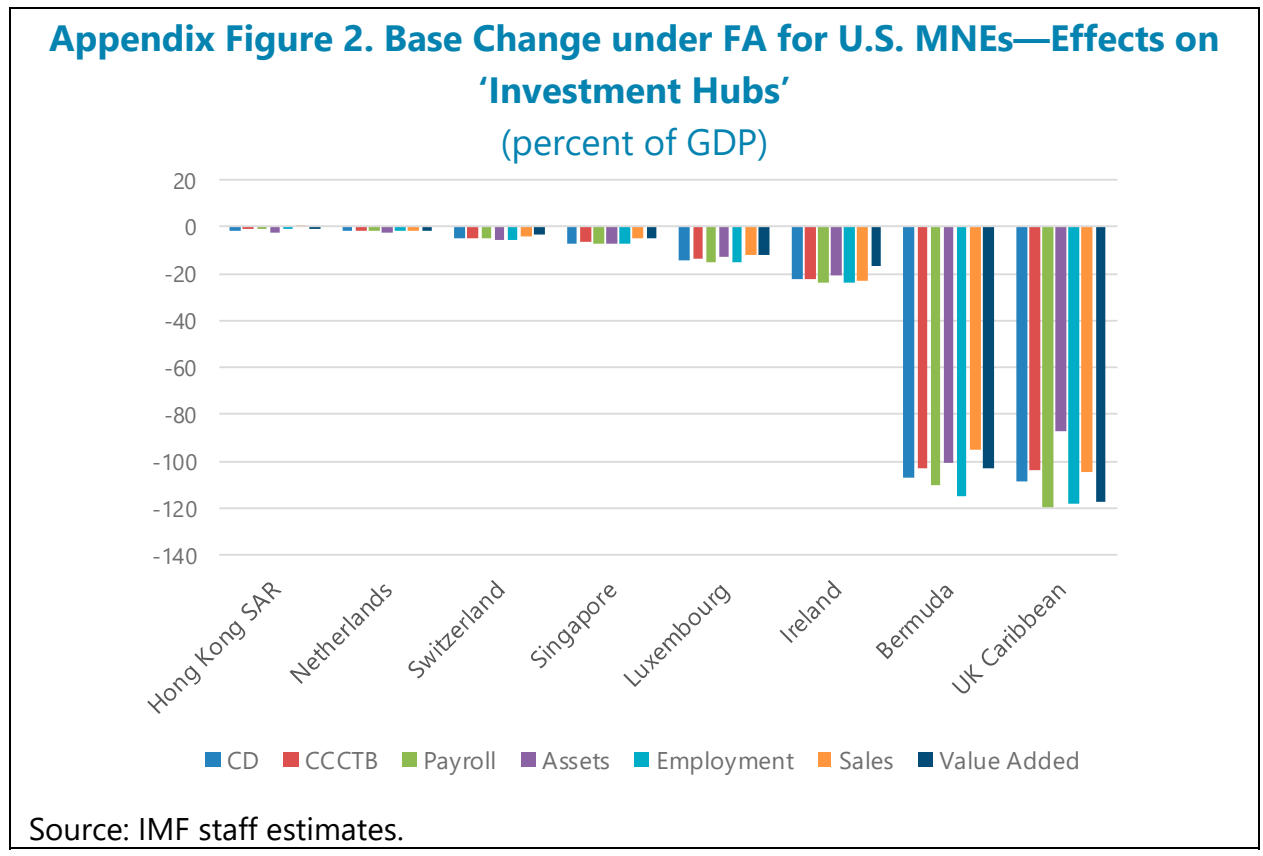


7. At unchanged tax rates, global CIT revenue will rise under FA due to a reallocation of tax bases from low to high tax countries. The revenue impact of these tax base changes is found by multiplying the change in the tax base in each country by the prevailing statutory CIT rate:

$$
\Delta \text { Revenue }_{f, i}=\tau_{\text {statutory }, i} \cdot \Delta \text { Base }_{f, i}
$$

Unlike the base effects, the aggregate revenue impact is likely to be non-zero, since corporate tax rates differ across countries. This is illustrated in Appendix Figure 3 for the case of FA with a valueadded formula. The figure ranks economies from left to right according to their base change. On average, countries that experience an expansion of their CIT base have a higher CIT rate than those suffering a reduction. ${ }^{3}$ The implication is that, at unchanged rates, global CIT revenue would-in relation to U.S. MNEs - be increased by common adoption of FA, reflecting a shift in tax base from low-tax to high-tax countries. The estimated increase ranges between 5.7 percent for the employment formula and 12.1 percent for the payroll formula. ${ }^{4}$

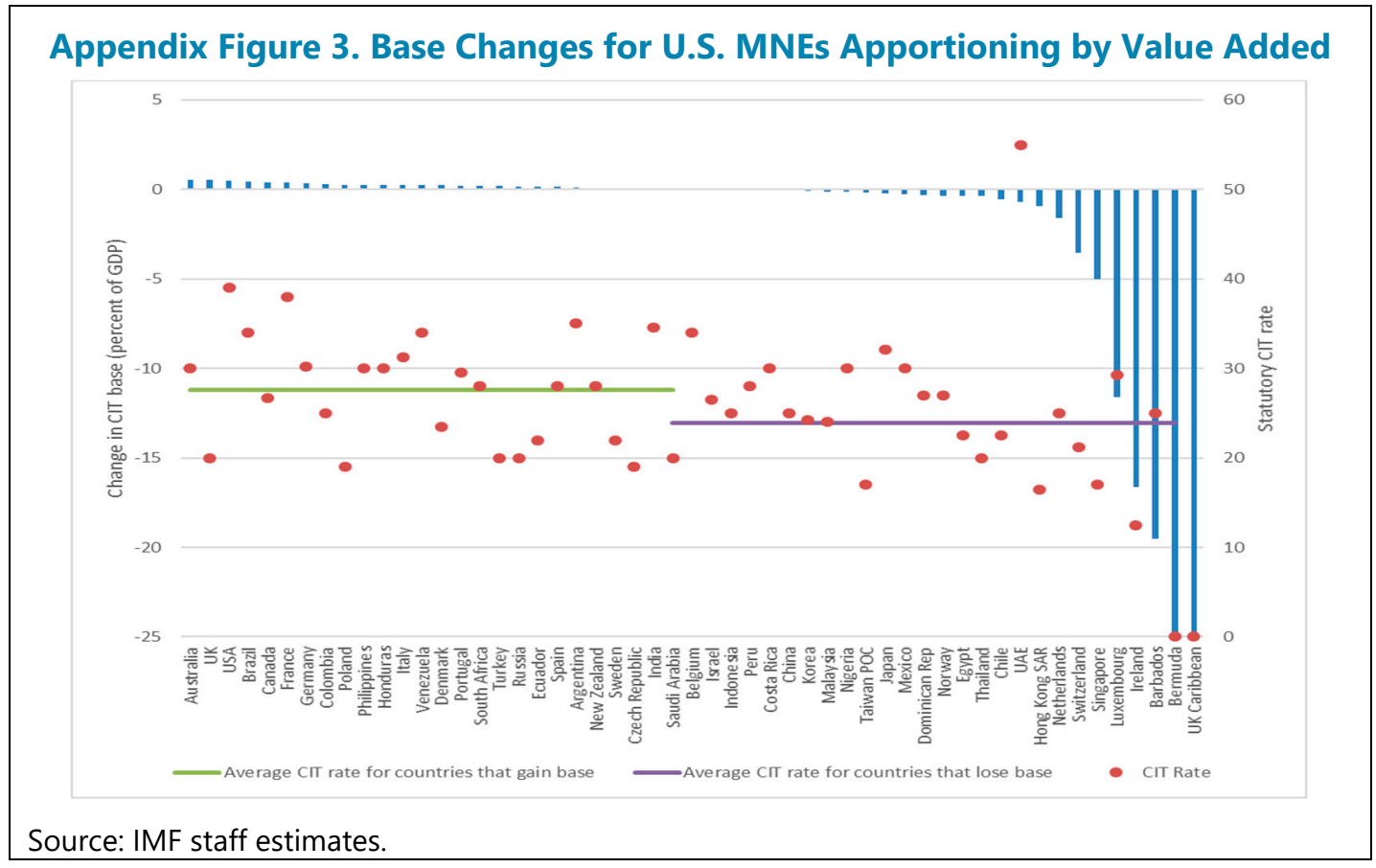

\section{Analysis Based on Firm-level Data}

The micro data extends the analysis beyond U.S. MNEs and enables estimating the impact of loss consolidation. The same analysis as above is performed using firm-level data from ORBIS, provided by Bureau van Dijk. This exercise follows Cobham and Loretz (2014), with some

\footnotetext{
${ }^{3}$ Differences in not only statutory tax rates but in tax incentives may affect the ultimate revenue effects of FA.

${ }^{4}$ For other weighting schemes, the increase is: assets 10 percent, value added 7.7 percent, sales 7.4 percent, CD 11.4 percent and СССТВ 8.8 percent.
} 
modifications and using more recent data. The sample consists of unconsolidated company financial statements for affiliates that are part of an MNE group. ${ }^{5}$ In selecting MNE groups, the unconsolidated statements are matched with the sample of consolidated accounts for which information on the balance sheet of the parent company is available. ${ }^{6}$ The sample is restricted to subsidiaries for which the sum of employment in the unconsolidated account represents at least 70 percent of employment reported in the consolidated financial statement, to ensure that the data are representative for the MNE affiliates. ${ }^{7}$ The final sample comprises 58,345 unique affiliates operating in 7,772 MNE groups during 2009-2016. It consists of subsidiaries of European-based MNEs (80 percent), but with extensive information on their activities in the rest of the world, including in 20 middle-income countries and one low-income country (Kyrgyz Republic).

\section{Cross-border loss consolidation under FA modestly reduces global CIT revenue. To} explore the effect of unitary taxation on the global tax base of MNEs, profits and losses before taxation of all subsidiaries in an MNE group for a given year are added up. If this sum is negative, the loss is carried forward at the group level, while recording a zero-taxable profit in the current year. Summing up these MNE corporate tax bases produces a measure for the aggregate tax base under unitary taxation. This is then compared to the tax base under separate accounting (SA), which assumes a carry-forward of losses at the affiliate level but no group relief. ${ }^{8}$ For 2016 , the overall tax base under unitary taxation is 3.7 percent smaller than that under separate accounting.

9. Tax base effects from FA are again significant. Only two single-factor formulas are considered with the firm-level data: the number of employees and value-added (calculated as gross sales minus the costs of goods sold); this is because the destination of sales is not available from ORBIS and information about payroll is missing for many emerging market economies. After computing the profit allocation for each individual subsidiary, the FA tax bases are aggregated by country of operation. The country-specific results-the excess of the FA tax base over the SA tax base in percent of the latter-are shown in Appendix Figure 4. As for the analysis with BEA data, several countries regarded as 'investment hubs' experience a significant reduction in their tax base under both FA factors. Moreover, middle-income countries are more likely to gain under the employment factor than under the value-added factor. For some countries, the difference between the two FA factors is very large, sometimes even larger than that between FA and SA.

\footnotetext{
${ }^{5}$ An MNE group is defined as one in which at least one subsidiary is in a different country from the parent. Subsidiaries are part of an MNE group if they are majority owned by the ultimate parent (directly or indirectly).

${ }^{6}$ The matching process combines the parent companies with the corresponding subsidiaries where the identification of the parent company is available.

${ }^{7}$ While this selection restricts the sample size, it overcomes the caveat that the coverage of subsidiaries comprising an MNE group in ORBIS is limited and may not provide a representative picture of the worldwide activities for such an MNE.

${ }^{8}$ This is an upper bound on the tax base under SA, as some countries allow for domestic relief/loss consolidation.
} 
10. The net revenue effect of shifts in the tax base to high-tax countries and cross-border loss consolidation is small. As in the previous analysis, the aggregate revenue effects of FA are computed, which is now the result of two offsetting effects. On the one hand, the smaller global tax base as a result of loss consolidation reduces global CIT revenue. On the other hand, the reallocation of the tax base from low-tax countries to high-tax countries increases it. On balance, global CIT revenue declines by 0.5 percent if the employment weight is used, and increases by 0.8 percent if the value-added weight is used.

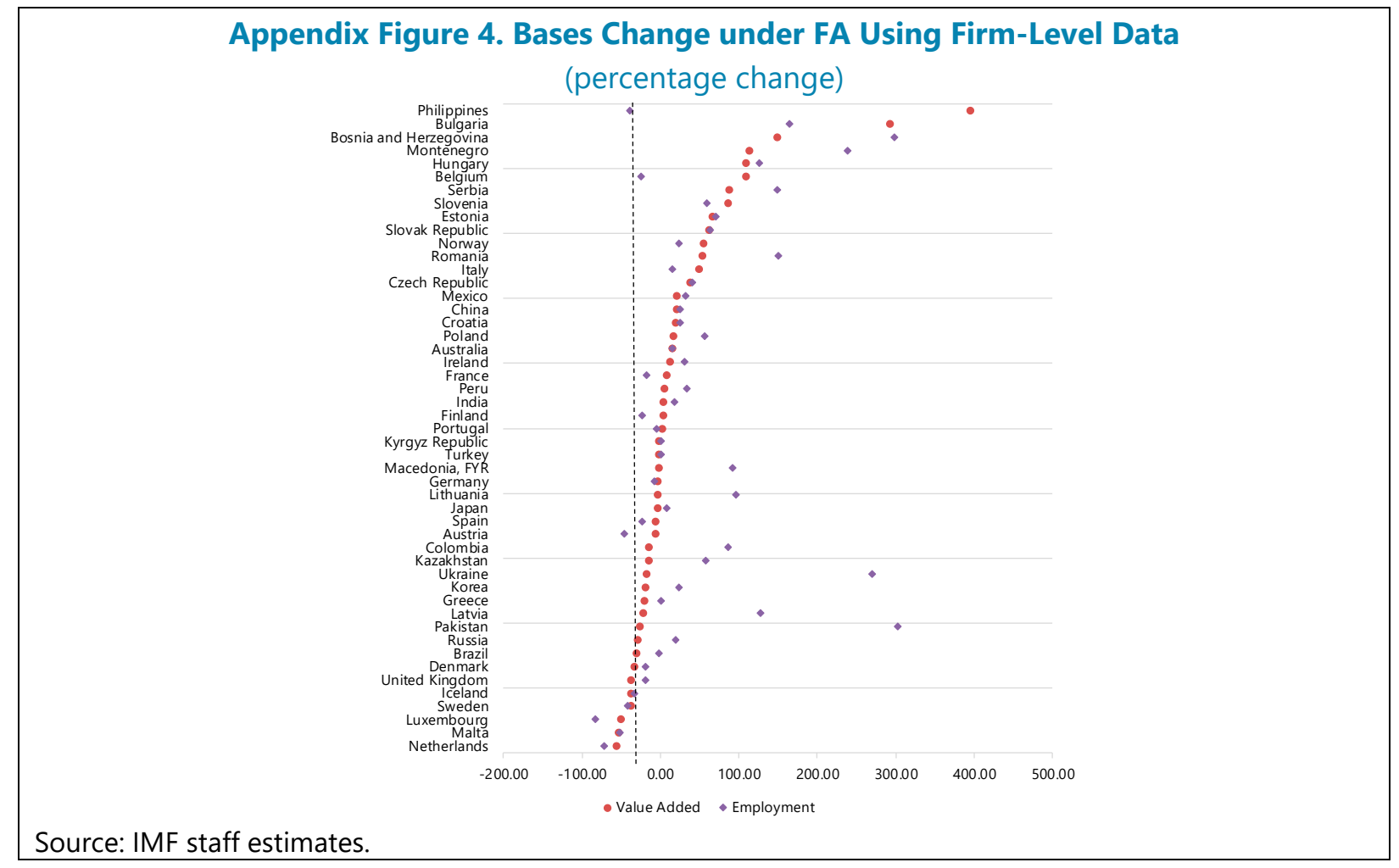




\section{Appendix X. The Scale and Allocation of Routine and Residual Profits}

\section{This appendix combines micro- and macro data to provide empirical evidence on the} scale and cross-country distribution of routine and residual returns. The first section quantifies the overall size of residual returns, including relative to routine returns, using consolidated financial statements of the world's largest 10,000 companies. Exploiting macroeconomic data for 51 countries, it also examines the allocation of routine returns across countries. The second section employs a simple theoretical model in combination with micro- and macro data to derive the revenue effects from implementing a destination-based RPA mechanism.

\section{Micro Analysis of Routine and Residual Profit}

2. Residual returns are defined at the consolidated multinational group level. The consolidated profit of any MNE $i$, denoted $\pi_{i}$, can be expressed as:

$$
\pi_{i}=\text { Routine }_{i}+R_{i}
$$

where, Routine $_{i}$ denotes its routine profit (which broadly corresponds to a normal return on the underlying real activities of MNEs, and can be calculated by applying some notional return to the assets of MNEs or as a markup to the costs of these activities) and $R_{i}$ its residual profit.

\section{Financial statements for the largest 10,000 companies in the S\&P Capital IQ database} allow inferring the size of routine and residual returns. After basic data cleaning, the baseline sample comprises 7,641 MNEs. In 2017, these companies jointly own total assets of US\$658 trillion, total net fixed assets (including property, plant, and equipment) of US $\$ 30$ trillion, and report US $\$ 5.5$ trillion of taxable profits. Appendix Table 1 lists the number of companies, as well as their respective shares of fixed assets and earnings before tax (EBT) in three different country groups: Advanced Economies (AEs), Emerging Economies (EMEs), and Low-Income Countries (LICs) (based on the country of the headquarters). Appendix Table 2 provides the same information across industries and reports the actual rate of return on fixed assets (that is, reported EBT relative to fixed assets) in Column 4 and the actual mark-up ratio over the costs of goods sold (defined as EBT over costs of goods sold). ${ }^{1}$ These two ratios show at which rate the normal returns would equate the EBT for the average MNE in the particular industry. For example, on average MNEs in manufacturing would require a 14 percent return on their fixed assets to declare all their EBT as normal profits. The weighted average ratio of EBT over fixed assets is 12 percent, while the average mark-up is 13 percent.

\footnotetext{
${ }^{1}$ Costs of goods sold include all intermediate purchases from third parties and direct labor costs, and hence is a lower bound of total costs of production by excluding indirect costs.
} 


\begin{tabular}{|lccc|}
\hline \multicolumn{4}{c|}{ Appendix Table 1. Descriptives by HQ Location } \\
\cline { 2 - 4 } Headquartered in & Number of & Share of Fixed & Share of \\
Advanced Economies & Companies & Assets (\%) & EBT (\%) \\
Emerging Markets & 5,476 & 64.5 & 74.2 \\
Low-Income Developing Countries & 2,065 & 35.2 & 25.4 \\
HQ Unknown & 24 & 0.1 & 0.1 \\
\cline { 2 - 4 } Source: IMF staff calculation based on S\&P Capital IQ database. & 18 & 0.22 & 0.30 \\
\hline
\end{tabular}

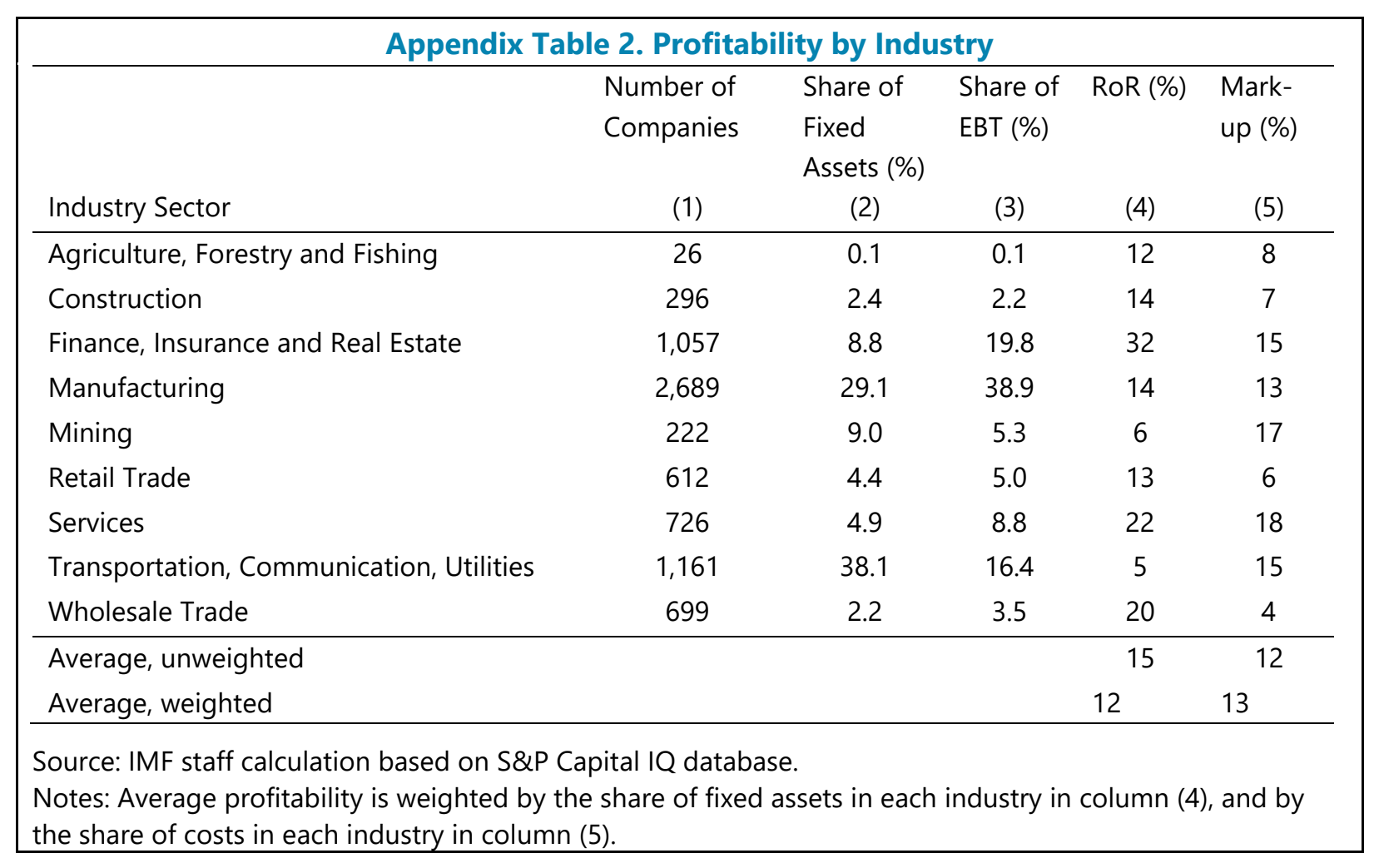

\section{For a considerable proportion of firms in the sample, the computed routine return} exceeds the corporations' reported earnings before taxes, thus implying a negative residual.

In the notation of equation (1), returns before taxes (EBT) are used to measure an MNE's

consolidated profits, $\pi_{i}$, and two methods then used an approximate routine component, $r_{i} K_{i}$ : (i) $\mathrm{A}$ cost mark-up approach, presuming that routine profit is 7.5 percent of the firm's total costs of goods sold (as in Avi-Yonah and others, 2009); and (ii) A notional return approach, which presumes tangible fixed assets provide a 10 percent routine return (in the spirit of GILTI). Residual profit is defined as the difference between EBT and the routine profit. The routine returns are somewhat lower than the average returns reported in Appendix Table 2, so that firms will on average report positive residual profits. However, this does not hold for all firms. The share of companies with a negative residual profit is 44 percent when using the mark-up ratio and 32 percent under the notional return approach. These shares decrease slightly when using earnings before interest, taxes, depreciation, and amortization (EBITDA) as the profit measure. They are also smaller when assuming 
lower routine returns: using a mark-up ratio of 4 percent, for instance, (the lowest industry-level average in Appendix Table 3), reduces the share of companies with a negative residual to 25 percent; with a notional RoR of 5 percent, the share of companies with a negative residual is 16 percent.

\section{Positive residual returns are highly concentrated among a few firms. The 100} companies with the largest residual, roughly one percent of the sample, account for one third of total residual returns. Among these firms, the ratio of residual return to profit is 85 percent. In comparison, the ratio of residual return to profit is 58 percent for all firms with a positive residual and the average ratio is -147 percent for the full sample. Since the major share of the aggregate residual return is earned by a few MNEs, the major share of the aggregate residual return is earned by a few MNEs that are headquartered in a small number of countries. Table 3 lists the 10 economies with the largest amount of residual returns, for varying rates of cost mark-up and return to fixed assets, and the proportion of all residual profit which they account.

\begin{tabular}{|c|c|c|c|c|c|c|c|c|c|c|}
\hline \multicolumn{11}{|c|}{ Appendix Table 3. Residual Profit by Country of Headquarters } \\
\hline \multirow{3}{*}{$\begin{array}{l}\text { Allocation method: } \\
\text { Rate: }\end{array}$} & \multicolumn{5}{|c|}{ Cost Mark-Up } & \multicolumn{5}{|c|}{ Notional Return to Assets } \\
\hline & \multicolumn{2}{|c|}{$7.5 \%$} & \multicolumn{3}{|c|}{$10 \%$} & \multicolumn{3}{|r|}{$7.5 \%$} & \multicolumn{2}{|l|}{$10 \%$} \\
\hline & $\begin{array}{c}\text { Share of } \\
\text { Global RP }\end{array}$ & $\begin{array}{c}\text { Mean } \\
\text { RP/EBT }\end{array}$ & & $\begin{array}{c}\text { Share of } \\
\text { Global RP }\end{array}$ & $\begin{array}{l}\text { Mean } \\
\text { RP/EBT }\end{array}$ & & $\begin{array}{c}\text { Share of } \\
\text { Global } \\
\text { RP }\end{array}$ & $\begin{array}{c}\text { Mean } \\
\text { RP/EBT }\end{array}$ & $\begin{array}{l}\text { Share of } \\
\text { Global RP }\end{array}$ & $\begin{array}{c}\text { Mean } \\
\text { RP/EBT }\end{array}$ \\
\hline United States & $37 \%$ & $53 \%$ & United States & $53 \%$ & $37 \%$ & United States & $34 \%$ & $44 \%$ United States & $49 \%$ & $25 \%$ \\
\hline United Kingdom & $7 \%$ & $43 \%$ & United Kingdon & $8 \%$ & $24 \%$ & Japan & $17 \%$ & $71 \%$ Japan & $38 \%$ & $62 \%$ \\
\hline China & $6 \%$ & $15 \%$ & Hong Kong & $6 \%$ & $61 \%$ & United Kingdom & $10 \%$ & 51\% United Kingdom & $17 \%$ & $35 \%$ \\
\hline Hong Kong SAR & $4 \%$ & $71 \%$ & Russia & $6 \%$ & $61 \%$ & Germany & $5 \%$ & $37 \%$ Hong Kong SAR & $9 \%$ & $60 \%$ \\
\hline Japan & $4 \%$ & $17 \%$ & Spain & $5 \%$ & $50 \%$ & Hong Kong SAR & $4 \%$ & 70\% Switzerland & $6 \%$ & $44 \%$ \\
\hline Russia & $4 \%$ & $71 \%$ & Australia & $4 \%$ & $55 \%$ & France & $4 \%$ & $34 \%$ Germany & $6 \%$ & $16 \%$ \\
\hline Germany & $3 \%$ & $26 \%$ & Canada & $4 \%$ & $36 \%$ & South Korea & $3 \%$ & $36 \%$ Ireland & $4 \%$ & $72 \%$ \\
\hline South Korea & $3 \%$ & $38 \%$ & South Korea & $3 \%$ & $18 \%$ & Switzerland & $3 \%$ & $58 \%$ France & $4 \%$ & $13 \%$ \\
\hline Spain & $3 \%$ & $63 \%$ & Venezuela & $3 \%$ & $99 \%$ & Spain & $2 \%$ & $40 \%$ South Korea & $4 \%$ & $14 \%$ \\
\hline France & $3 \%$ & $27 \%$ & Switzerland & $2 \%$ & $23 \%$ & India & $2 \%$ & $48 \%$ Venezuela & $3 \%$ & $92 \%$ \\
\hline Rest of the World & $27 \%$ & & ROW & $5 \%$ & & ROW & $16 \%$ & RoW & $-39 \%$ & \\
\hline
\end{tabular}

\section{National accounts and additional macro-data allow approximating the current} distribution of routine and residual returns across countries. Specifically, aggregate information on non-financial fixed capital formation is combined with a presumed depreciation rate to approximate country-specific capital stocks for a sample of 51 countries. Routine returns, of both domestic and multinational companies, then follow from multiplying these stocks with a presumed rate of return.

\section{The taxation of routine returns would likely foster government revenue in developing}

countries. Assuming a notional rate of return of 10 percent, Appendix Figure 1 reports estimated routine returns by country, and Appendix Figure 2 the excess of the current tax base over routine returns (under two different assumed rates of return on tangibles). Magnitudes are expressed as a share of GDP and thus do not add up to some hypothetical aggregate residual. A significant share of routine returns is currently located in low tax jurisdictions. A sensitivity analysis shows that assuming a lower depreciation rate increases the estimated revenues from routine returns whereas assuming a lower return to fixed assets decreases estimated revenues from routine returns (results are not reported). Figure 2 depicts the difference between current $\mathrm{CIT}$ revenues and revenues from taxing 
routine returns (would be taxed at the current statutory CIT rates). The unweighted average increase in CIT revenue of 'winner countries' is 1.53 percent of GDP. The unweighted average decrease in CIT revenue for the other countries is 1.47 percent of GDP.
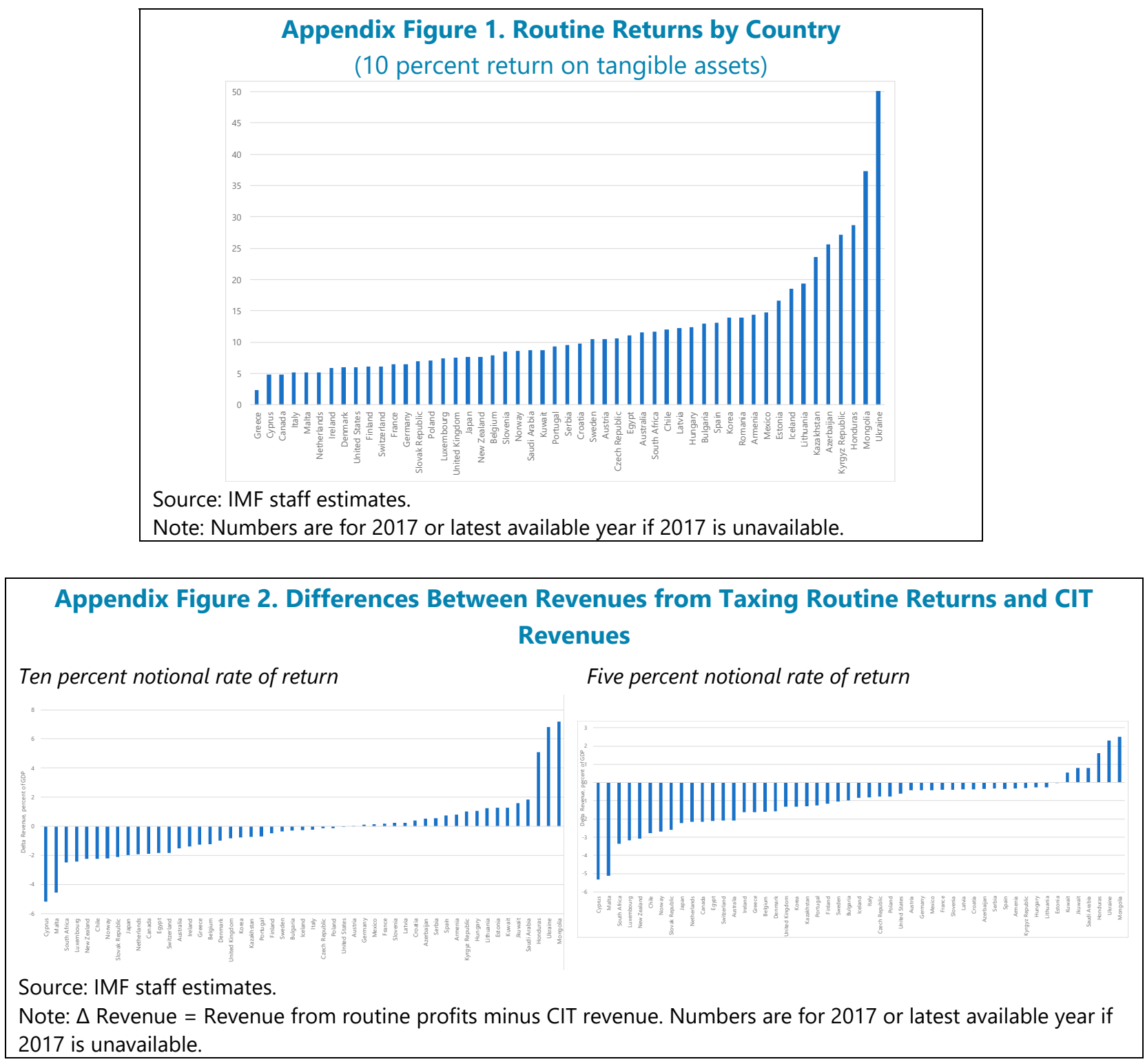

\section{Revenue Implications of Moving to an RPA Mechanism}

\section{This section combines micro- and macro data with a simple theoretical model to} gauge total revenue effects of implementing an RPA mechanism. For simplicity, the section assumes that profit shifting is restricted to residual returns. The total revenue effect of implementing an RPA mechanism thus depends on the current and on the future allocation of residual returns, both of which are derived using a simple theoretical model. 
9. The model considers an MNE using intra-group transactions to maximize its global after-tax profit under the current tax system. Specifically, the MNE uses intra-group transaction to reallocate its consolidated residual returns $R$ across countries $c=1, \ldots N$. However, any excess of reported taxable earnings over routine returns, denoted by $D_{c}$, triggers $\operatorname{cost} \mathrm{c}\left(D_{c}\right)$ in this location. Accounting for the constraint that all residual returns are reported in some location, the MNE's optimization problem is summarized by:

$$
\max _{D_{c}} \sum_{c}\left[D_{c}\left(1-t_{i}\right)-c\left(D_{c}\right)\right]-\lambda\left[\sum_{c} D_{c}-R\right]
$$

where $t_{c}$ is the statutory tax rate in country $i$ and $\lambda$ is the Lagrangian multiplier associated with the equality constraint that all residual returns need to be reported. ${ }^{2}$

The marginal costs of profit-shifting are assumed to be inversely proportional to i) the countryspecific tangible capital stock, $K_{c}$; and, ii) the ratio of the MNE's residual profit to its aggregate capital stock, $K$ :

$$
c^{\prime}\left(D_{c}\right)=\frac{1}{\gamma} \frac{D_{c}}{K_{c}} \frac{K}{R}
$$

where $\gamma>0$ i determines the overall cost of profit-shifting. This specification implies that profit shifting is only possible with positive residual returns and is less costly with economic substance.

\section{The first-order conditions of the MNE's optimization problem imply that the excess of} reported taxable earnings in country $\mathrm{c}$ is given by:

$$
D_{c}=R k_{c}\left[1-\gamma \Delta \tau_{c}\right]
$$

where $k_{c}=\frac{K_{c}}{K}$ is the share of total fixed assets employed in location I and $\Delta \tau_{c}=\frac{1}{K} \sum_{j} K_{j}\left(t_{c}-t_{j}\right)$
is an asset weighted tax rate differential between country $\mathrm{c}$ and the rest of the corporate group. This equation reflects the assumption that residual returns are essential for profit-shifting: reported and real profit coincide under the current international tax architecture only in the absence of residual returns. Otherwise, reported and real returns differ, and more residual returns are reported where tax rates are lower (as suggested by the negative sign on $\gamma \Delta \tau_{i}$ ).

\section{Under the current international tax framework, country-specific tax bases may exceed or fall short of aggregate routine returns located in this country. Using equation (4) and}

\footnotetext{
${ }^{2}$ Note that this formulation ignores the MNE's tax liability and return associated with location-specific capital stocks, which are unaffected by the optimal allocation of residual returns. For simplicity, the formulation also ignores the usual asymmetry in the treatment of profit and losses.
} 
accounting for the routine returns in this location shows that the tax base in country $c$ can be expressed, summing over MNEs indexed by $i$, as:

$$
T B_{c}^{\text {now }}=\sum_{i}\left[r_{i} K_{i c}+R k_{i c}\left(1-\gamma \Delta \tau_{i c}\right)\right]
$$

Because of tax minimization schemes, excess taxable returns (depicted in equation 4) tend to be positive in low-tax countries and negative in high-tax countries, suggesting that reported tax bases in high-tax countries falls short of routine returns and tend to exceed them in low-tax countries.

\section{Under an RPA mechanism, all countries would be entitled to fully tax routine returns.} The RPA proposal starts from MNEs' consolidated residual returns $R_{i}$ and allocates this residual based on some allocation factor. Denoting country c's allocation share by $\omega_{c}$, country-specific tax bases under the new regime are:

$$
T B_{c}^{R P A}=\sum_{i}\left[r_{i} K_{i c}+D_{i c}^{*}\right] \text { where } D_{i c}^{*}=\omega_{c} R_{i} \geq 0 .
$$

since aggregate residual returns are assumed to be non-negative, equation (6) implies that countries would be entitled to fully tax routine returns. Note that this conclusion rests on the assumption that residual returns at the consolidated group level are a prerequisite for profit shifting.

\section{The total effect of implementing an RPA method depends on the current and future} distribution of the total residual. This can easily be seen by subtracting equation (5) from (6), giving:

$$
T B_{c}^{R P A}-T B_{c}^{\text {now }}=R\left[\left(\omega_{c}-k_{c}\right)+\gamma k_{c} \Delta \tau_{c}\right]
$$

where $R=\sum_{i} R_{i}$ is the aggregate residual, $k_{c}$ is the share of total fixed assets located in country c, $\Delta \tau_{c}$ is an assets-weighted tax differential between country $\mathrm{c}$ and other locations, and $\gamma$ is a hypothetical cost of profit shifting parameter. ${ }^{3}$ The equation formalizes the above result: countries with large $\omega_{c}$ 's relative to the country's tangible asset stock will benefit from adopting the RPA mechanism (indicated by $\left(\omega_{c}-k_{c}\right)$ ), as will countries that currently impose a relatively high tax burden on corporations (indicated by $\gamma k_{c} \Delta \tau_{c}$ ).

14. For instance, using destination-based sales as an allocation key, the implementation of an RPA mechanism would benefit economies with large consumption bases and large CIT rates. The main difference between a country's GDP and domestic sales are its net exports. Partly, destination-based sales may also show up as an intermediate input in the national accounts. Countries with negative trade balances would thus likely benefit from implementation of an RPA mechanism with destination-based sales as an allocation factor, as would countries with high

\footnotetext{
${ }^{3}$ In contrast, if the location of fixed capital is irrelevant for the allocation of reported profit, equation (5) would change to $R\left[\left(\omega_{i}-\frac{1}{N}\right)+\gamma \frac{1}{K} \widetilde{\Delta \tau}_{l}\right]$, where $\widetilde{\Delta \tau}_{\iota}$ is now an unweighted average tax differential.
} 
statutory tax rates since these countries' tax bases are eroded due to profit shifting under current rules.

\section{To simulate the revenue effect of implementing an RPA mechanism using destination-} based sales, equation (7) is combined with various data sources. Specifically, equation (7) expresses total effects from moving to an RPA mechanism as a function of five components: (i) destinationbased sales, (ii) relative capital stocks, (iii) tax-rate differentials, (iv) a parameter reflecting the cost of profit shifting, and (v) the aggregate residual which is to be reallocated. None of these measures is directly observed. The annex combines national consumption (private plus public) with gross fixed capital formation to proxy for destination-based sales; ${ }^{4}$ it relies on country-specific CIT rates in combination with estimated capital stocks to compute tax-rate differentials; presumes a hypothetical profit shifting parameter of $1.5 ;$ and draws on the micro-data to quantify the aggregate residual.

\section{Figure 8 in the text combines these, sometimes opposing effects, in illustrating the} redistribution of the tax base. The results build on a simple model, using various data sources, and thus need to be interpreted with caution. ${ }^{6}$ Light-blue bars indicate tax base effects stemming from country-specific differences in their consumption vs. capital intensity (the first term in (7)); dark-blue bars illustrate tax base reallocation stemming from tax-rate differentials (the second).

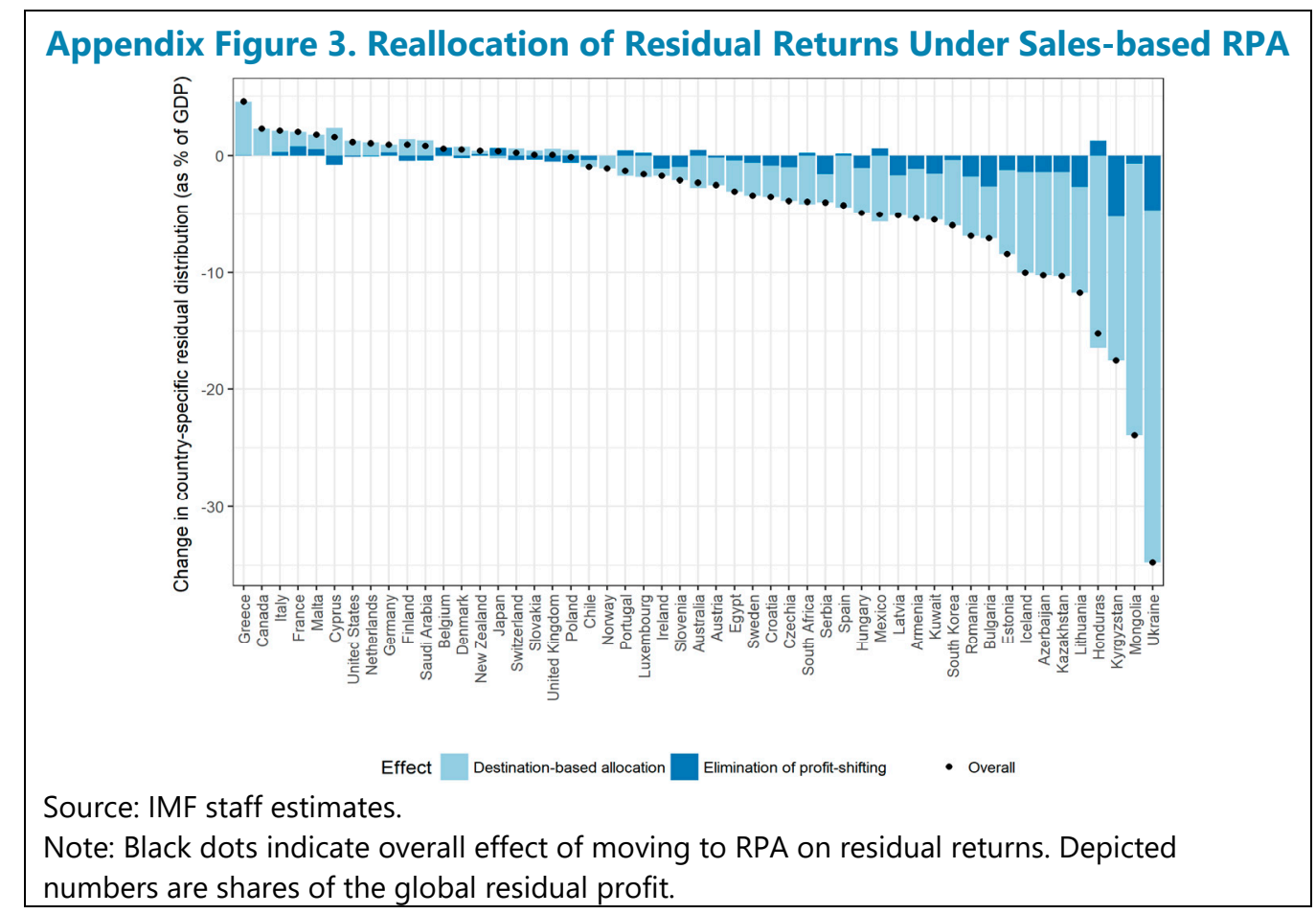

\footnotetext{
${ }^{4}$ Intermediate inputs, which are not captured by the difference between GDP and net exports, are disregarded in this annex. The implicit assumption is that all intermediate inputs are purchased from related parties.

${ }^{5}$ Following prior work by Beer and others (2018), a cost parameter of $\gamma=1.5$ is assumed in equation (7).

${ }^{6}$ The results are point estimates. The multiplicity of employed proxy-variables (such as destination-based sales) with unknown probability distributions inhibits straight-forward sensitivity analyses or the computation of confidence bands.
} 


\section{References}

Altshuler, Rosanne, and Harry Grubert, 2009, "Formula Apportionment? Is it Better Than the Current System and are There Better Alternatives?" National Tax Journal, Vol. 63, pp. 1145-1184.

Auerbach, Alan, 2017, "Demystifying the Destination-Based Cash-Flow Tax," Brookings Papers on Economic Activity, pp. 409-432.

Auerbach, Alan and Michael P. Devereux, 2018, "Cash-flow Taxes in an International Setting," American Economic Journal: Economic Policy, Vol. 10, pp. 69-94.

Auerbach, Alan, Michael P. Devereux, Michael Keen, and John Vella, 2017a, "Destination-based Cash Flow Taxation," Oxford University Centre for Business Taxation Working Paper No. 17/01 (Oxford: Saïd Business School).

__ 2017b, "International Tax Planning Under the Destination-based Cash Flow Tax," National Tax Journal, Vol. 70, pp. 783-802.

Auerbach, Alan, Michael P. Devereux, Michael Keen, Paul Oosterhuis, and John Vella, 2019, "Residual Profit Allocation by Income," Oxford University Centre for Business Taxation Working Paper No. 19/01 (Oxford: Saïd Business School).

Avi-Yonah, Reuven and Kimberly A. Clausing, 2008, Reforming Corporate Taxation in a Global Economy: A Proposal to Adopt Formulary Apportionment. Hamilton Project, The Brookings Institution Discussion Paper 2007-2008.

Avi-Yonah, Reuven, Kimberly A. Clausing, and Michael C. Durst, 2009, "Allocating Business Profits for Tax Purposes: A Proposal to Adopt a Formulary Profit Split," Florida Tax Review, Vol. 9, pp. 497-553.

Avi-Yonah and Haiyan Xu, 2017, "Evaluating BEPS," Erasmus Law Review, No. 1, pp. 1-11.

Baker, Paul, 2014, "An Analysis of Double Tax Treaties and their Effect on Foreign Direct Investment, International Journal of Economics and Business," Vol. 21, pp. 341-377.

Barbiero, Omar, Emmanuel Farhi, Gita Gopinath, and Oleg Itskhoki, 2018, "The Macroeconomics of Border Taxes," NBER Working Paper No. 24702 (Cambridge, Massachusetts: National Bureau of Economic Research).

Becker, Johannes and Clemens Fuest, 2012, "Transfer Pricing Policy and the Intensity of Tax Rate Competition," Economics Letters, Vol. 117, pp. 146-148. 
Becker, Johannes, Joachim Englisch, and Deborah Schanz, 2018, "How Data Should (not) be Taxed," Mimeo, (Münster, University of Münster) https://papers.ssrn.com/sol3/papers.cfm?abstract id =3289036

Beer, Sebastian, Ruud de Mooij, and Li Liu, 2019, "International Corporate Tax Avoidance: A Review of the Channels, Magnitudes, and Blind Spots," Journal of Economic Surveys, forthcoming.

—_, Ruud de Mooij, and Li Liu, 2018, "International Corporate Tax Avoidance: A Review of the Channels, Effect Sizes, and Blind Spots," IMF Working Paper No. 18/168 (Washington: International Monetary Fund).

Beer, Sebastian, Alexander Klemm, and Thornton Matheson, 2018, "Tax Spillovers from U.S. Corporate Tax Reform," IMF Working Paper No. 18/166 (Washington: International Monetary Fund).

Beer, Sebastian, and Jan Loeprick, 2017, "Taxing Income in the Oil and Gas Sector-Challenges of International and Domestic Profit Shifting," Energy Economics, Vol. 61, pp. 186-198.

_ 2018, The Cost and Benefits of Tax Treaties with Investment Hubs: Findings from subSaharan Africa, IMF Working Paper No. 18/227 (Washington: International Monetary Fund).

Beer, Sebastian, Maria Coelho, and Sebastien Leduc, 2019, "Hidden Treasure: The Impact of Automatic Exchange of Information on Cross-Border Tax Evasion." Forthcoming IMF Working Paper (Washington: International Monetary Fund).

Best, Michael, Anne Brockmeyer, Henrik Kleven, Johannes Spinnewijn, and Mazhar Waseem, 2015, "Production Versus Revenue Efficiency with Limited Tax Capacity: Theory and Evidence from Pakistan," Journal of Political Economy, Vol. 123, pp. 1311-1355.

Bettendorf, Leon, Michael Devereux, Albert van der Horst, Simon Loretz, and Ruud de Mooij, 2010, "Corporate Tax Harmonization in the EU," Economic Policy, Vol. 25, pp. 537-90.

Boadway, Robin and Michael Keen, 2010, "Theoretical Perspectives on Resource Tax Design" in The Taxation of Petroleum and Minerals: Principles, Practices and Problems, eds. by Philip Daniel, Michael Keen, and Charles McPherson, pp. 14-74 (London: Routledge, New York: Routledge).

Bond, Stephen, and Michael P. Devereux, 2002, "Cash Flow Taxes in an Open Economy," CEPR Discussion Paper No. 3401 (London: Center for Economic and Policy Research).

Bradbury, David, Tibor Hannapi, and Anne Moore, 2018, "Estimating the Fiscal Effects of Base Erosion and Profit Shifting: Data Availability and Analytical Issues," Transnational Corporations: Investment and Development, Vol. 25, pp. 91-106. 
Brennan, Geoffrey and James M. Buchanan, 1980, "The Power to Tax: Analytical Foundations of a Fiscal Constitution," in The Collected Works of James M. Buchanan, (Cambridge: Cambridge University Press).

Buiter, Willem H., 2017, "Exchange Rate Implications of Border Tax Adjustment Neutrality," Economics: The Open-Access, Open-Assessment E-Journal, Vol. 11, pp. 1-41.

Casi, Elisa, Christoph Spengel and Barbara Stage, 2018, "Cross-Border Tax Evasion After the Common Reporting Standard: Game Over?" ZEW Discussion Paper No. 18-36.

Chalk, Nigel, Michael Keen, and Victoria Perry, 2018, "The Tax Cuts and Jobs Act: An Appraisal," IMF Working Paper No. 18/185 (Washington: International Monetary Fund).

Clausing, Kimberly, 2016, "The U.S. State Experience Under Formulary Apportionment: Are There Lessons for International Reform?" National Tax Journal, Vol. 69, pp. 353-386.

_ 2018a, "Profit Shifting Before and After the Tax Cuts and Jobs Act," Mimeo, (Oregon: Reed College) https://papers.ssrn.com/sol3/papers.cfm?abstract id=3274827.

_ 2018b, "Does Tax Drive the Headquarters of the World's Biggest Companies?" Transnational Corporations: Investment and Development, Vol. 25, pp. 37-64.

Cobham, Alex, and Petr Janský, 2018, "Global Distribution of Revenue Loss from Corporate Tax Avoidance: Re-estimation and Country Results," Journal of International Development, Vol. 30, pp. 206-232.

Cobham, Alex and Simon Loretz, 2014, "International Distribution of the Corporate Tax Base: Implications of Different Apportionment Factors Under Unitary Taxation," ICTD Working Paper No. 27 (Brighton: International Centre for Tax and Development).

Cockfield, Arthur, 2018," Shaping International Tax Law and Policy in Challenging Times," Stanford Journal of International Law, Vol. 54, pp. 223-240.

Collier, Richard, and Joseph L. Andrus, 2017, Transfer Pricing and the Arm's Length Principle After BEPS (Oxford: Oxford University Press).

Commission of the European Communities, 1992, Report of the Committee of Independent Experts on Company Taxation (Luxembourg: Office for Official Publications of the European Communities).

Crivelli, Ernesto, Ruud de Mooij, and Michael Keen, 2016, "Base Erosion, Profit Shifting and Developing Countries," FinanzArchiv, Vol. 72, pp. 268-301. 
Daly, Michael, 2016, "Is the WTO a World Tax Organization? A Primer for WTO Rules for Policy Makers," IMF Technical Note and Manual No. 2016-03 (Washington: International Monetary Fund).

Damgaard, Jannick, and Thomas Elkjaer, 2017, "The Global FDI Network: Searching for Ultimate Investors," IMF Working Paper No. 17/258 (Washington: International Monetary Fund).

Daniels, Joseph, Patrick O'Brien, and Marc von der Ruhr, 2015, Bilateral Tax Treaties and U.S. Foreign Direct Investment Financing Modes, International Tax and Public Finance, Vol. 22, pp. 9991027.

De Mooij, Ruud, and Li Liu, 2018, "At a Cost: The Real Effects of Transfer Pricing Regulations," IMF Working Paper No. 18/69 (Washington: International Monetary Fund).

Devereux, Michael, and John Vella, "Implications of Digitalization for International Corporate Tax Reform," 2017, pp. 91-112 in Sanjeev Gupta and others (eds), Digital Revolutions in Public Finance (Washington: International Monetary Fund).

Devereux, Michael, and Simon Loretz, 2008, "The Effects of EU Formula Apportionment on Corporate Tax Revenues," Fiscal Studies, Vol. 29, pp. 1-33.

Dharmapala, Dhammika, 2018, "The Consequences of the Tax Cut and Jobs Act's International Provisions: Lessons from Existing Research," National Tax Journal, Vol. 71, pp. 707-728

Durst, Michael, 2015, "The Tax Policy Outlook for Developing Countries: Reflections on International Formulary Apportionment," ICTD Working Paper No. 32 (Brighton: International Centre for Tax and Development).

European Commission, 2014, Expert Group on Taxation of the Digital Economy: Report https:/ec.europa.eu/taxation customs/business/company-tax/tax-good-governance/expertgroup-taxation-digital-economy en\#section 5

- 2016a, Proposals for a Council Directive on a Common Corporate Tax Base and a Common Consolidated Corporate Tax Base (CCCTB), COM No. 683 (Brussels: European Commission).

_ 2016b, Impact Assessment Accompanying the Document Proposals for a Council Directive on a Common Corporate Tax Base and a Common Consolidated Corporate Tax Base (CCCTB) (Brussels: European Commission).

_ 2016c, Proposal for a Council Directive on a Common Corporate Tax Base, COM (2016) 685 final. (Brussels: European Commission). 
_ 2018a, Proposal for a Council Directive Laying Down Rules Relating to the Corporate Taxation of a Significant Digital Presence, COM No. 147 (Brussels: European Commission).

- 2018b, Proposal for a Council Directive on the Common System of a Digital Services Tax on Revenue Resulting from the Provision of Certain Digital Services, COM No. 148 (Brussels: European Commission).

European Council, 1998, "Conclusion of the ECON Council Meeting on 1 December 1997 concerning taxation policy,' Official Journal of the European Communities, Vol. 6.1.98, No. C2, pp. 1-6.

Fuest, Clemens, Shafik Hebous, and Nadine Riedel, 2011, "International Debt Shifting and Multinational Firms in Developing Economies," Economics Letters, Vol. 113, pp. 135-138.

Gordon, Roger H., and John D. Wilson, 1986, "An Examination of Multijurisdictional Corporate Income Taxation Under Formula Apportionment," Econometrica, Vol. 54, pp. 1357-1373.

Grinberg, Itai, 2017, "A Destination-based Cash Flow Tax Can be Structured to Comply with World Trade Organization Rules," National Tax Journal, Vol. 70, pp. 803-818.

— 2018, "International Taxation in the Era of Digital Disruption: Analyzing the Current Debate," mimeo, Georgetown University Law Center https://scholarship.law.georgetown.edu/facpub/2118/.

Gupta, Sanjeev, Michael Keen, Alpa Shah, and Geneviève Verdier, 2017, Digital Revolutions in Public Finance (Washington: International Monetary Fund).

Hebous, Shafik and Alexander Klemm, 2018, "A Destination-Based Allowance for Corporate Equity," IMF Working Paper No. 18/239 (Washington: International Monetary Fund).

__ and Saila Stausholm, 2019, "Revenue-Implications of Destination-Based Cash-Flow Taxation," IMF Working Paper No. 19/07 (Washington: International Monetary Fund).

Hellerstein, Jerome, 1993, "Federal Income Taxation of Multinationals: Replacement of Separate Accounting with Formulary Apportionment," Tax Notes No. 10, pp. 1131-1145.

Hines Jr., James R., 2010, "Income Misattribution Under Formula Apportionment, " European Economic Review, Vol. 54, pp. 108-120.

HM Treasury, 2018a, Corporate Tax and the Digital Economy: Position Paper Update, https://assets.publishing.service.gov.uk/government/uploads/system/uploads/attachment d ata/file/689240/corporate tax and the digital economy update web.pdf. 
_ 2018b, Budget 2018: Digital Services Tax

https://assets.publishing.service.gov.uk/government/uploads/system/uploads/attachment d ata/file/752172/DST web.pdf.

Hong, Qing, and Michael Smart, 2010, “In Praise of Tax havens: International Tax Planning and Foreign Direct Investment", European Economic Review, Vol. 54, pp. 82-95.

Hong, Sunghoon, 2018, "Tax Treaties and Foreign Direct Investment: A Network Approach," International Tax and Public Finance, Vol. 25, pp. 1277-1320.

Hufbauer, Gary C., and Zhiyao (Lucy) Lu, 2018, "The European Union's Proposed Digital Services Tax: A de facto Tariff," Policy Brief 18-15, (Washington: Petersen Institute for International Economics).

Hutton, Eric, 2017, "The Revenue Administration-Gap Analysis Program: Model and Methodology for Value-Added Tax Gap Estimation," IMF Technical Note and Manual No. 04/07 https://www.imf.org/en/Publications/TNM/Issues/2017/04/07/The-RevenueAdministrationGap-Analysis-Program-Model-and-Methodology-for-Value-Added-Tax-Gap$\underline{44715}$

Independent Commission for the Reform of International Corporate Taxation, 2018, A Roadmap to Improve Rules for Taxing Multinationals (United Kingdom: Oxford) https://static1.squarespace.com/static/5a0c602bf43b5594845abb81/t/5a78e6909140b73efc0 8eab6/1517872798080/ICRICT+Unitary+Taxation+Eng+Feb2018.pdf

International Monetary Fund, 2009, "Debt Bias and Other Distortions: Crisis-Related Issues in Tax Policy," IMF Policy Paper (Washington) https://www.imf.org/external/np/pp/eng/2009/061209.pdf.

_ 2012, "Fiscal Regimes for Extractive Industries_Design and Implementation", IMF Policy Paper (Washington) https://www.imf.org/external/np/pp/eng/2012/081512.pdf

- 2014, "Spillovers in International Corporate Taxation," IMF Policy Paper (Washington) https://www.imf.org/external/np/pp/eng/2014/050914.pdf.

- 2015, "Current Challenges in Revenue Mobilization_Improving Tax Compliance," IMF Policy Paper (Washington) https://www.imf.org/external/np/pp/eng/2015/020215a.pdf

_ 2016, "Tax Policy, Leverage, and Macroeconomic Stability," IMF Policy Paper (Washington) https://www.imf/external/np/pp/2016/100716.pdf.

- 2018a, Capitalizing on Good Times, Fiscal Monitor (April) https://www.imf.org/en/Publications/FM/Issues/2018/04/06/fiscal-monitor-april-2018 
_ 2018b, A Decade after the Global Financial Crisis: Are we Any Safer? Global Financial Stability Report: https://www.imf.org/en/Publications/GFSR/Issues/2018/09/25/Global-FinancialStability-Report-October-2018

International Monetary Fund, Organisation for Economic Cooperation and Development, 2017, Tax Certainty: Report for the G20 Finance Ministers (Washington) https://www.imf.org/external/np/g20/pdf/2017/031817.pdf

- 2018, Update on Tax Certainty: Report for the G20 Finance Ministers and Central Bank Governors http://www.oecd.org/tax/g20-report-on-tax-certainty.htm.

International Monetary Fund, Organisation for Economic Cooperation and Development, World Bank, and United Nations, 2015, Options for Low Income Countries' Effective and Efficient Use of Tax Incentives for Investment: A Report to the G-20 Development Working Group https://www.imf.org/external/np/g20/pdf/101515.pdf

Johanessen Niels, 2014, "Tax Evasion and Swiss Bank Deposits," Journal of Public Economics, Vol. 111, pp. 46-62.

Johannesen, Niels and Gabriel Zucman, 2014, "The End of Bank Secrecy? An Evaluation of the G-20 Tax Haven Crackdown," American Economic Journal: Economic Policy, Vol. 6, pp. 65-91.

Johannesen, Niels, Thomas Tørsløv, and Ludvig Wier, 2016, "Are Less Developed Countries More Exposed to Multinational Tax Avoidance? Method and Evidence from Micro-Data," World Institute for Development Economics Research, Working Paper Series 010.

Kadet, Jeffery M., Tommaso Faccio, and Sol Picciotto, 2018, "Profit-Split Method: Time for Countries to Adopt a Standardized Approach," Tax Notes International, (July), pp. 359-362.

Keen, Michael, 2002, "Preferential Regimes Can Make Tax Competition Less Harmful," National Tax Journal, Vol. 54, pp. 757-762.

- 2018, "Competition, Coordination and Avoidance in International Taxation," Bulletin of International Taxation, Vol. 72, No. 4/5, pp. 220-225.

Keen, Michael, and Kai Konrad, 2013, "The Theory of International Tax Competition and Coordination," in Alan Auerbach, Raj Chetty, Martin Feldstein and Emanuel Saez (eds) Handbook of Public Economics, Vol. 5, pp. 257-328 (Amsterdam: North Holland).

Kind, Has Jarle, Marko Koethenbuerger, and Guttorm Schjelderup, 2008, "Efficiency Enhancing Taxation in Two Sided Markets," Journal of Public Economics, Vol. 92, pp. 1531-1539.

__ 2010, "Tax Responses in Platform Industries," Oxford Economic Papers, Vol. 62, pp. 764-783. 
Konrad, Kai, and Guttorm Schjelderup, 1999, "Fortress Building in Global Tax Competition", Journal of Urban Economics, Vol. 46, pp. 156-167.

Konrad, Kai, and Marcel Thum, 2018, "The Better Route to Global Tax Coordination: Gradualism or Multilateralism?" CESifo Working Paper No. 7305.

Land, Bryan C., 2010, "Resource Rent Taxes: A Re-Appraisal," in Philip Daniel, Michael Keen and Charles McPherson (eds) The Taxation of Petroleum and Minerals: Principles, Practices and Problems, pp. 241-262 (London; New York: Routledge).

Lane, Philip R., and Gian M. Milesi-Ferretti, 2017, "International Financial Integration in the Aftermath of the Global Financial Crisis, IMF Working Paper No. 17/115 (Washington: International Monetary Fund).

Lennard, Michael, 2009, "The UN Model Tax Convention as Compared with the OECD Model Convention: Current Points of Difference and Recent Developments," Asia-Pacific Tax Bulletin, pp. 4-11.

Li, Jinyan, 2002, "Global Profit Split: An Evolutionary Approach to International Income Allocation," Canadian Tax Journal, Vol. 50, pp. 823-883.

Luckhaupt, Hagen, Michael Overesch, and Ulrich Schreiber, 2010, "The OECD Approach to Transfer Pricing: A Critical Assessment and Proposal," in Wolfgang Schön and Kai Konrad (eds), Fundamentals of International Transfer Pricing in Law and Economics, pp. 91-121 (Berlin: Springer Verlag).

Lund, Diderik, 2009, "Rent Taxation for Non-renewable Resources," Annual Review of Resource Economics, Vol. 1, pp. 287-308.

Mansour, Mario, and Grégoire Rota-Graziosi, 2013, "Tax Coordination, Tax Competition, and Revenue Mobilization in the West African Economic and Monetary Union," IMF Working Paper No. 13/163 (Washington: International Monetary Fund).

Marques, Mario, and Carlos Pinho, 2014, "Tax-Treaty Effects on Foreign Investment: Evidence from European Multinationals, FinanzArchiv, Vol. 70, pp. 527-555.

Meade, James E., 1978, The Structure and Reform of Direct Taxation: Report of a Committee Chaired by Professor J.E. Meade for the Institute for Fiscal Studies (George Allen \& Unwin: London).

McLure, Charles E. Jr., and Joann M. Weiner, 2000, “Deciding Whether the European Union Should Adopt Formula Apportionment of Company Income", in Taxing Capital Income in the European Union. Issues and Options for Reform, Sijbren Cnossen (ed.), pp. 243-292 (Oxford: Oxford University Press). 
Menkhoff, Lukaz, and Jakob Miethe, 2017, "Dirty Money Coming Home: Capital Flows Into and Out of Tax Havens," German Institute of Economic Research, Discussion Paper No. 1711.

Nielsen, Søren Bo, Pascalis Raimondos-Møller, and Guttorm Schjelderup, 2010, "Company Taxation and Tax Spillovers: Separate Accounting versus Formula Apportionment," European Economic Review, Vol. 54, pp. 121-132.

Nicolay, Katharina, Hannah Nusser, and Olena Pfeiffer, 2017, "On the Interdependency of Profit Shifting Channels and the Effectiveness of Anti-Avoidance Legislation," Discussion Paper No. 17-066, (Mannheim, Germany: Centre for Economic Research).

Organisation for Economic Cooperation and Development, 1998, Harmful Tax Competition: An Emerging Global Issue (Paris).

- 2015a, Addressing the Tax Challenges of the Digital Economy, Action 1-Final Report (Paris). http://www.oecd.org/ctp/addressing-the-tax-challenges-of-the-digital-economy-action-12015-final-report-9789264241046-en.htm

_ 2015b, Designing Effective Controlled Foreign Company Rules-Action 3: 2015, in the Final Report. http://www.oecd.org/tax/designing-effective-controlled-foreign-company-rulesaction-3-2015-final-report-9789264241152-en.htm

- 2015c, Countering Harmful Tax Practices More Effectively, Taking into Account Transparency and Substance, Action 5-2015, Final Report. http://www.oecd.org/ctp/countering-harmfultax-practices-more-effectively-taking-into-account-transparency-and-substance-action-52015-final-report-9789264241190-en.htm

- 2015d, Transfer Pricing Documentation and Country-by-Country Reporting, Action 13-2015 Final Report, G-20 /OECD Base Erosion and Profit Shifting Project, (Paris). http://dx.doi.org/10.1787/9789264241480-en.

- 2015e: Measuring and Monitoring BEPS: Action 11-Final Report, (Paris) http://www.oecd.org/ctp/measuring-and-monitoring-beps-action-11-2015-final-report9789264241343-en.htm

- 2015f, OECD/G20 Base Erosion and Profit Shifting Project: Explanatory Statement, (Paris) https://www.oecd.org/ctp/beps-explanatory-statement-2015.pdf.

- 2018a, "Revised Guidance on the Application of the Transactional Profit Split Method," (Paris). https://www.oecd.org/tax/transfer-pricing/revised-guidance-on-the-application-of-thetransactional-profit-split-method-beps-action-10.pdf. 
_ 2018b, Tax Challenges Arising from Digitalisation-Interim Report (Paris). https://read.oecdilibrary.org/taxation/tax-challenges-arising-from-digitalisation-interimreport 9789264293083-en\#page1

Overesch, Michael, 2009, "The Effects of Multinationals' Profit Shifting Activities on Real Investments, National Tax Journal, Vol. 62, pp. 5-23.

Oxfam, 2017, "Blacklist or Whitewash? What a Real EU Blacklist of Tax Havens Should Look Like", Briefing Note, (November), (Oxford: United Kingdom).

Piccioto, Sol, 2016, "Taxing Multinational Enterprises as Unitary Firms," International Centre for Tax and Development, Working Paper No. 53, (Brighton, United Kingdom: International Centre for Tax and Development)

_ 2018, "Problems of Transfer Pricing and Possibilities for its Simplification," Working Paper No. 86, (Brighton, United Kingdom: International Centre for Tax and Development)

Platform for Collaboration on Tax, 2016, "Concept Note" http://www.worldbank.org/en/programs/platform-for-tax-collaboration

_ 2017, A Toolkit for Addressing Difficulties in Accessing Comparables Data for Transfer Pricing Analyses. http://documents.worldbank.org/curated/en/447901498066167863/The-platformfor-collaboration-on-tax-a-toolkit-for-addressing-difficulties-in-accessing-comparablesdata-for-transfer-pricing-analyse

— 2019, The Taxation of Offshore Indirect Transfers-A Toolkit, (forthcoming).

Rosenbloom, David H., Noam Noked, and Mohammed S. Helal, 2014, "The Unruly World of Tax: A Proposal for an International Tax Cooperation Forum," Florida Tax Review, Vol. 15, pp. 57-87.

Rosenthal, Steven M. 2017, "Slashing Corporate Taxes: Foreign Investors Are Surprise Winners." https://www.taxnotes.com/tax-notes/corporate-taxation/slashing-corporate-taxes-foreigninvestors-are-surprise-winners/2017/10/23/1x781

Saunders-Scott, Molly, 2015, "Substitution Across Methods of Profit Shifting, National Tax Journal Vol. 68, No. 4, pp. 1099-1120.

Schön, Wolfgang, 2007, "Group Taxation and the CCCTB," Tax Notes International, Vol. 48, (December), pp. 1063-1080.

, 2016, "Destination-based Income Taxation and WTO Law: A note," in Heike Jochum, Peter Essers, Michael Lang, Norbert Winkeljohann and Bertil Wiman (eds), Practical Problems in 
European and Intenratial Tax Law: Essays in Honour of Manfred Mössner, pp. 429-451 (Amsterdam: International Bureau of Fiscal Documentation).

— 2017, "Ten Questions about Why and How to tax the Digital Economy," Max Planck Institute for Tax Law and Public Finance, Working Paper No. 2017-2011.

Slemrod, Joel, 1995, "Free Trade Taxation and Protectionist Taxation" International Tax and Public Finance, Vol. 2, pp. 471-489.

Smart, Michael, 2007, "Raising Taxes through Equalization,"Canadian Journal of Economics, Vol. 40, pp. 1188-1212.

Spengel, Christoph, Martina Ortmann-Babel, Benedict Zinn, and Sebastian Matenaer, 2011," A Common Corporate Tax Base for Europe: An Impact Assessment of the Draft Council Directive on a CC(C)TB," ZEW Discussion Paper No. 39.

Sullivan, Martin A., 2018, "Economic Analysis: GILTI and That Disappointing Deemed Tangible Return, (May 8) https://www.taxnotes.com/tax-reform/economic-analysis-gilti-and-disappointingdeemed-tangible-return

Tanzi, Vito, 1995, Taxation in an Integrating World (Washington, D.C. Brookings Institution Press).

Tørsløv, Thomas, Ludvig Wier, and Gabriel Zucman, 2018, "The Missing Profits of Nations," NBER Working Paper No. 24701 (Cambridge: Massachusetts: National Bureau of Economic Research).

Trepelkov, Alex, Harry Tonino, and Dominika Halka, 2015, United Nations Handbook on Selected Issues in Protecting the Tax Base of Developing Countries (New York: United Nations).

Van't Riet, Maarten, and Arjan Lejour, 2017, "Optimal Tax Routing: Network Analysis of FDI Diversion, International Tax and Public Finance," Vol. 25, pp. 1321-1371.

Waerzeggers, Christophe, and Cory Hillier, 2016, Introducing a General Anti-Avoidance Rule (GAAR), Tax Law, IMF Technical Note, Vol.1(1), (Washington: International Monetary Fund).

Wei, Cui, 2018, "The Digital Services Tax: A Conceptual Defense", mimeo, University of British Columbia.

Weiner, Joann, 1999, "Using the Experience in the U.S. States to Evaluate Issues in Implementing Formula Apportionment at the International Level", OTA Paper No. 83, Office of Tax Analysis, (Washington, D.C.: U.S. Department of the Treasury). 